\title{
ANÁLISE DIALÉLICA ENVOLVENDO GENÓTIPOS PARENTAIS DE SOJA RESISTENTES AO NEMATÓIDE DE CISTO
}

\author{
ÂNGELA CELIS DE ALMEIDA LOPES
}

Engenheiro Agrônomo

Orientador: Prof. Dr. NATAL ANTONIO VELLO

Tese apresentada à Escola Superior de Agricultura "Luiz de Queiroz", Universidade de São Paulo, para obtenção do título de Doutor em Agronomia, Área de Concentração: Genética e Melhoramento de Plantas.

\author{
PIRACICABA \\ Estado de São Paulo - Brasil \\ Fevereiro - 2001
}


Dados Internacionais de Catalogaçāo na Publicaçāo (CIP) DIVISĀo DE BIBLIOTECA E DOCUMENTAÇĀO - Campus "Luiz de Queiroz"/USP

\section{Lopes, Ângela Celis Almeida}

Análise dialélica envolvendo genótipos parentais de soja resistentes ao nematóide de cisto / Ângela Celis Almeida Lopes. - - Piracicaba, 2001.

$122 \mathrm{p}$.

Tese (doutorado) - Escola Superior de Agricultura Luiz de Queiroz, 2001. Bibliografia.

1. Cruzamento dialélico 2. Genótipo vegetal 3. Melhoramento genético vegetal 4. Nematóide-de-cisto-soja 5. Parâmetro genético 6. Resistência ao parasito 7. Soja I. Título

CDD 633.34 


\section{AGRADECIMENTOS}

- Ao Professor Dr. Natal Antonio Vello, pela sua orientação e constante apoio.

- A Escola Superior de Agricultura "Luiz de Queiroz", Universidade de São Paulo, pela oportunidade de realizar o Curso de Pós-Graduação em Agronomia: Área de Concentração: Genética e Melhoramento de Plantas.

- Ao CNPq pela concessão da bolsa de estudos.

- Ao CNPq e FAPESP, pelo financiamento de projetos de pesquisa durante a fase de desenvolvimento do germoplasma principal avaliado neste trabalho.

- Ao convênio EMBRAPA-CNPSo e Fundação Mato Grosso pelo fornecimento de sementes da linhagem MTBR 123.800 utilizada nesta pesquisa.

- Ao convênio EMBRAPA-CNPDIA e Gil Equipamentos Especiais pela cessão do aparelho de Ressonância Nuclear Magnética para a realização das análises de teor de óleo.

- À minha família pelo apoio incondicional apesar da distância.

- Um agradecimento especial aos amigos Fábio Pandini, Andréa Mittelmann, Maurisrael de M. Rocha, Claudio Y. Tsutsumi, Alessandra P. Fávero, Gilberto K. Yokomizo, Sandra H. U. Trevisoli, Maria Aldete J. F. Ferreira, Ana Cláudia C. Badan, Antônio Ismael I. Cardoso, Maria I. Zucchi, Francisco C. C Lopes, Rogério de M. C. Pinto, Rainério Meireles, Wellington Araújo, Vanoli Fronza, Dario Hiromoto, Sérgio Carbonell, Maria C. Falco, Fernando T. Miranda e a todos aqueles que conheci no decorrer do curso.

- Aos queridos Ademir S. F. Araújo, Estela Kaminagakura, Maria C. A. Lopes, Dannyllo Antunes, Maria Teresa R. Lopes, Edson A. Bastos e Ranyse Silva por todos os maravilhosos momentos vividos em Piracicaba.

- Aos Drs. Francisco R. Freire Filho, Regina L. F. Gomes, José B. Pinheiro e Nelson F. Júnior pela amizade e sugestões na correção da Tese.

- Aos colegas do grupo da soja, pela amizade, apoio e companheirismo durante todo o curso.

- Aos funcionários do Setor de Genética Aplicada às Espécies Autógamas, Marcos C. Nekatschalow, Antônio R. Cogo e Claudinei A. Didoné, um agradecimento pelo apoio nas etapas de campo e de laboratório.

- A todos os funcionários do Departamento de Genética pela atenção gentilmente cedida.

- E a todos que de maneira direta ou indireta contribuiram para a realização deste trabalho. 


\section{SUMÁRIO}

Página

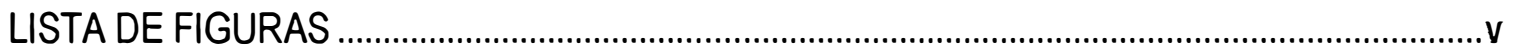

LISTA DE TABELAS ............................................................................................................. vii

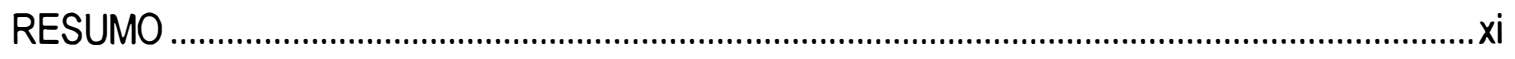

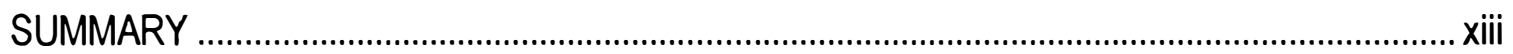

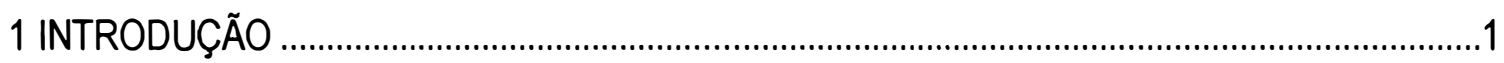

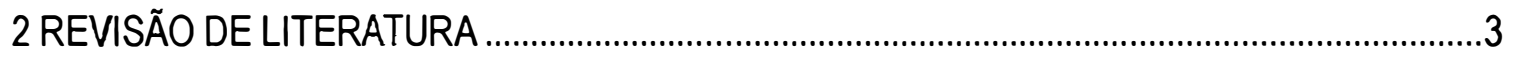

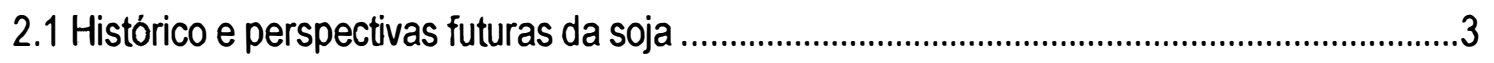

2.2 Etapas essenciais no programa de melhoramento .............................................................

2.3 Análise dialélica e sua importância ...................................................................................

2.4 Caracteres agronômicos em soja...................................................................................16

3 CORRELAÇÕES GENOTÍPICAS, FENOTÍPICAS E DE AMBIENTE EM CRUZAMENTOS

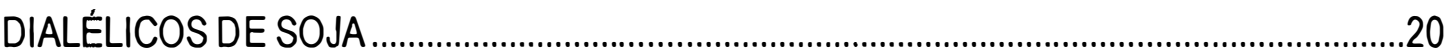

RESUMO

SUMMARY

3.1 INTRODUÇÃO

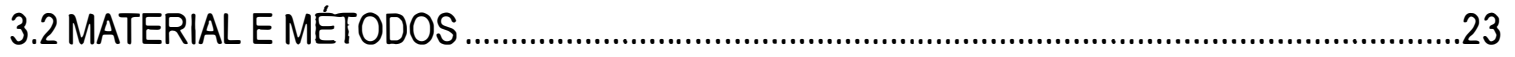

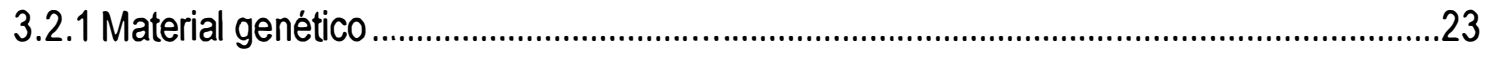

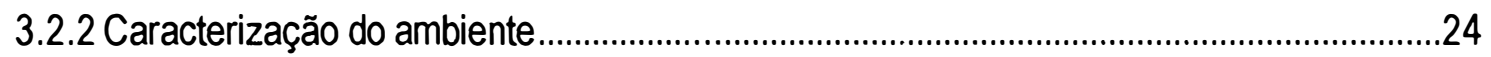

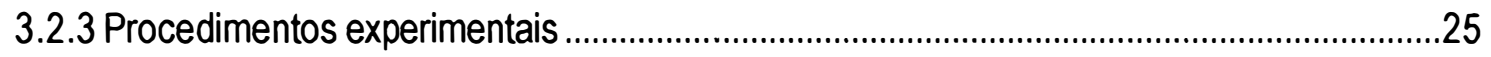

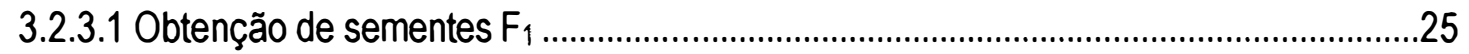

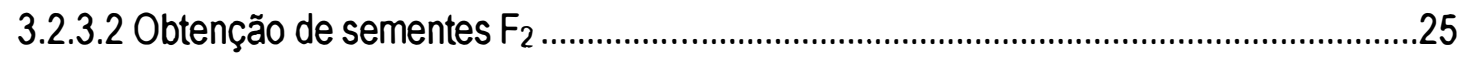

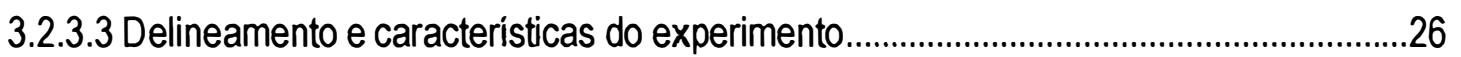

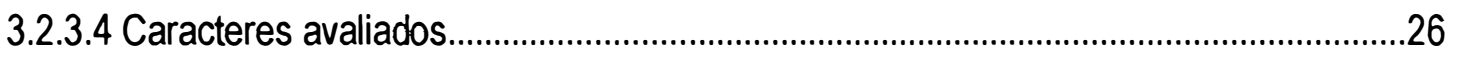

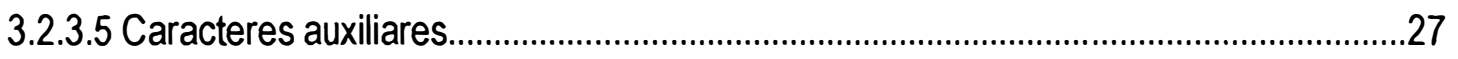

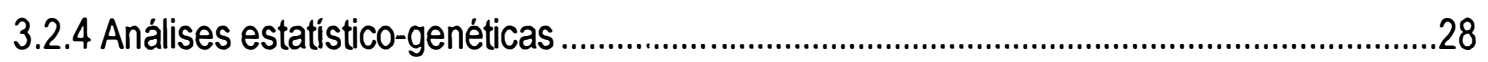

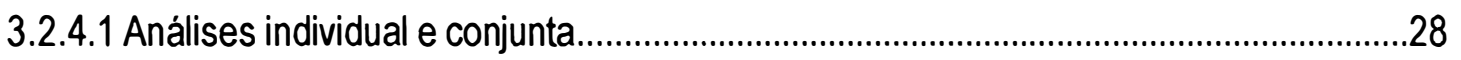

3.2.4.2 Análises de médias ....................................................................................29

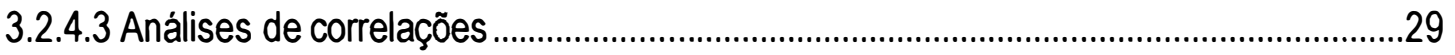

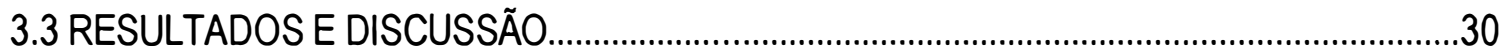

3.3.1 Análises de variâncias individuais ...............................................................................30

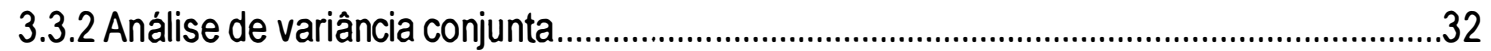

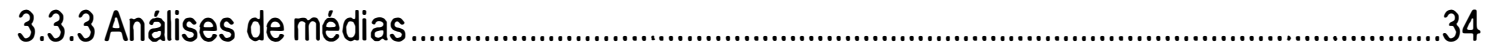


3.3.4 Correlações fenotipicas, genotipicas e ambientais. . .35

4 ANÁLISE DA CAPACIDADE COMBINATÓRIA EM SOJA. . .49

RESUMO. .49

SUMMARY. .50

4.1 INTRODUÇÃO

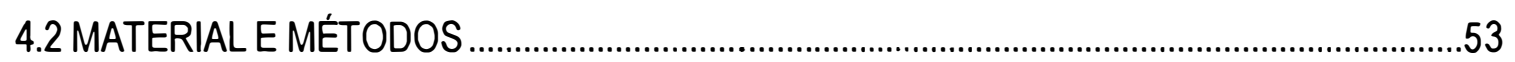

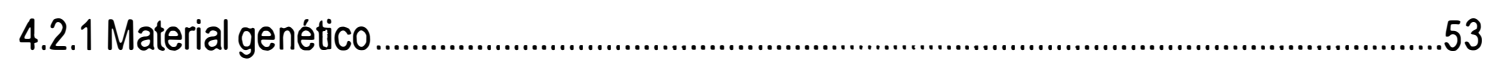

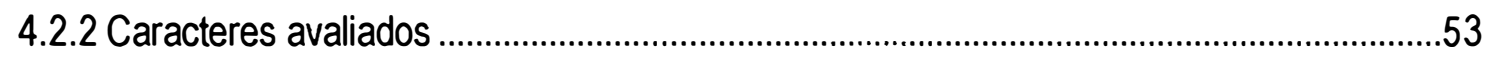

4.3 ANÁLISES ESTÍSTICO-GENÉTICAS ..............................................................................

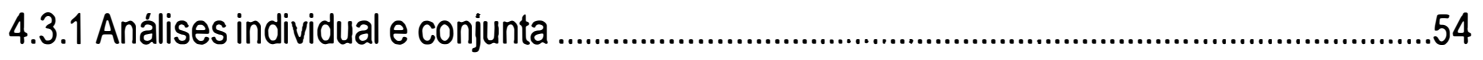

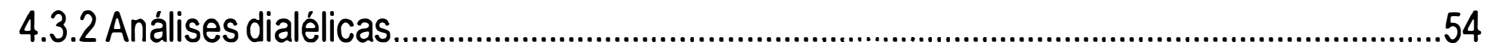

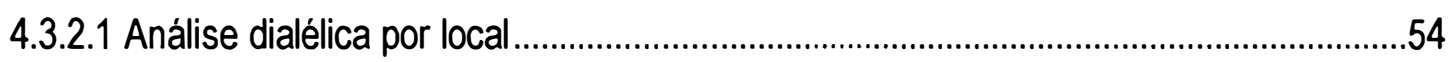

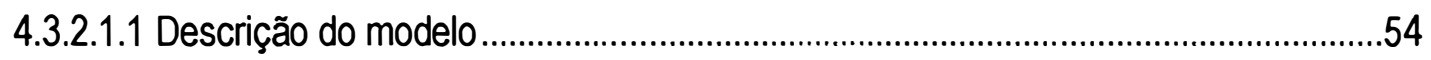

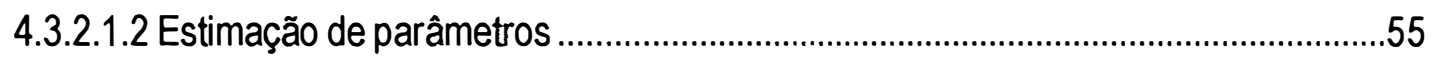

4.3.2.1.3 Estimação das somas de quadrados dos efeitos ..................................................56

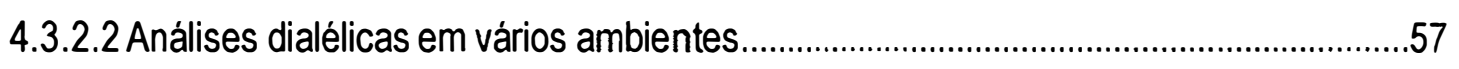

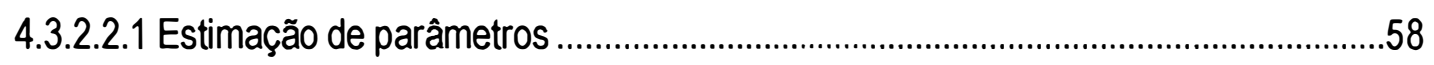

4.3.2.2.2 Estimação das somas de quadrados dos efeitos ..................................................60

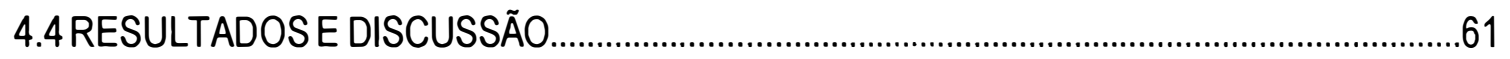

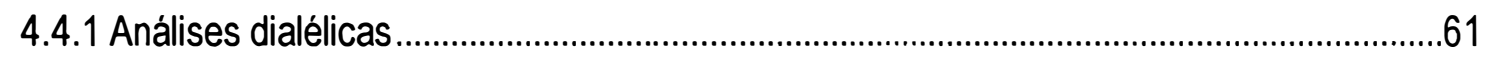

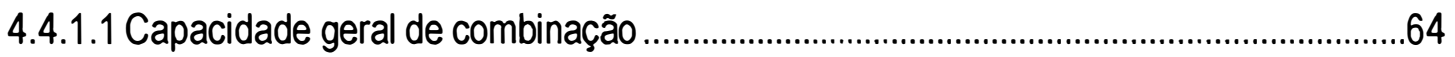

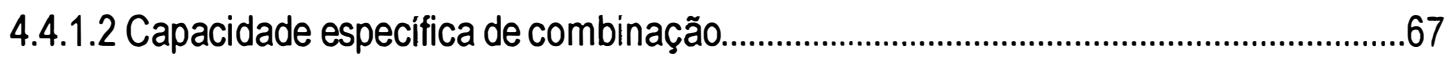

5 ANÁLISE DIALÉLICA DE HAYMAN ENTRE GENÓTIPOS DE SOJA ....................................81

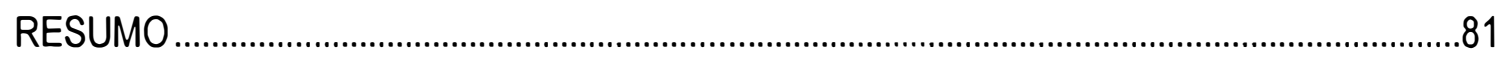

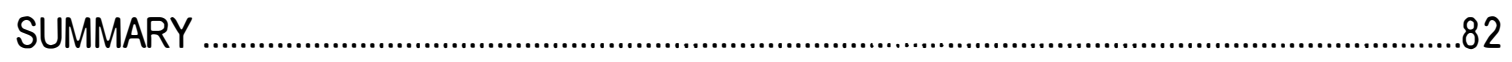

5.1 INTRODUÇÃO

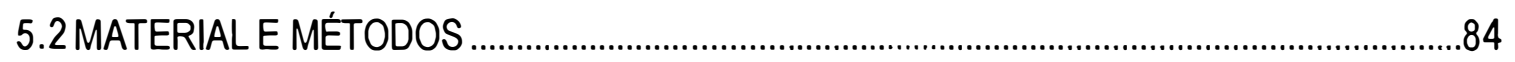

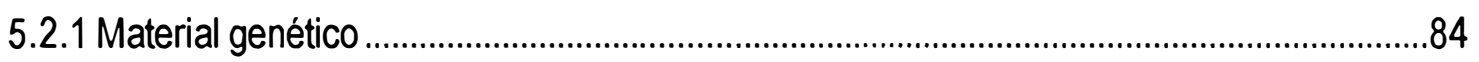

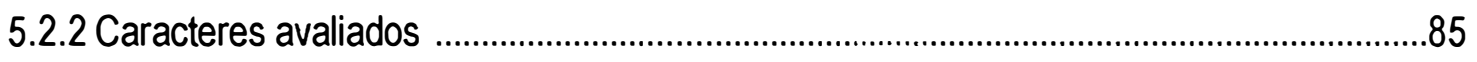

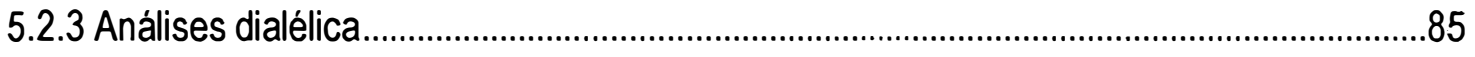

5.2.3.1 Teste de suficiência do modelo aditivo-dominante ......................................................86

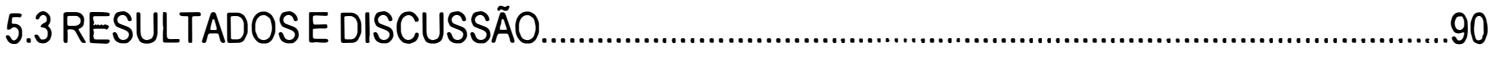

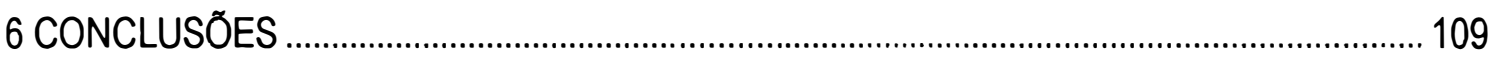

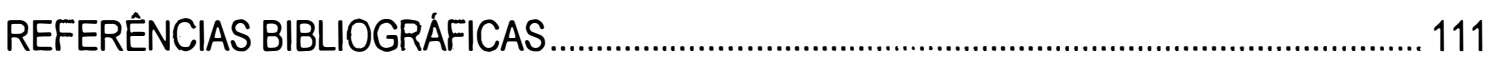




\section{LISTA DE FIGURAS}

Página

1 Regressão de Wi sobre Vi para o caráter número de dias para 0 florescimento (NDF). Parentais: 1-Hartwig; 2-Conquista; 3- USP 1-11; 4 USP 2-16; 5 - MTBR 123.800; 6 - USP 5-19. Análise de Hayman para um dialelo $6 \times 6$ com 15 cruzamentos $F_{2}$. Soja, semeadura em 09/11/98 (ESALQ) e 24/11/98 (Anhembi). Piracicaba-SP 102

2 Regressão de Wi sobre Vi para o caráter altura da planta no florescimento (APF). Parentais: 1-Hartwig; 2-Conquista; 3- USP 1-11; 4 - USP 2-16; 5 MTBR 123.800; 6 - USP 5-19. Análise de Hayman para um dialelo 6 × 6 com 15 cruzamentos $F_{2}$. Soja, semeadura em 09/11/98 (ESALQ) e 24/11/98 (Anhembi). Piracicaba-SP. 103

3 Regressão de Wi sobre Vi para o caráter número de dias para maturação (NDM). Parentais: 1-Hartwig; 2-Conquista; 3- USP 1-11; 4 - USP 2-16; 5 MTBR 123800; 6 - USP 5-19. Análise de Hayman para um dialelo $6 \times 6$ com 15 cruzamentos $F_{2}$. Soja, semeadura em 09/11/98 (ESALQ) e 24/11/98 (Anhembi). Piracicaba-SP. .104

4 Regressão de Wi sobre Vi para o caráter altura da planta na maturação (APM). Parentais: 1-Hartwig; 2-Conquista; 3- USP 1-11; 4 - USP 2-16; 5 MTBR 123.800; 6 - USP 5-19. Análise de Hayman para um dialelo $6 \times 6$ com 15 cruzamentos $F_{2}$. Soja, semeadura em 09/11/98 (ESALQ) e 24/11/98 (Anhembi). Piracicaba-SP 105

5 Regressão de Wi sobre Vi para o caráter produção de grãos (PG). Parentais: 1-Hartwig; 2-Conquista; 3- USP 1-11; 4 - USP 2-16; 5 - MTBR 123.800; 6 - USP 5-19. Análise de Hayman para um dialelo $6 \times 6$ com 15 cruzamentos F2. Soja, semeadura em 09/11/98 (ESALQ) e 24/11/98 (Anhembi). Piracicaba-SP 106

6 Regressão de Wi sobre Vi para o caráter porcentagem de óleo (\%OL). Parentais: 1-Hartwig; 2-Conquista; 3- USP 1-11; 4 - USP 2-16; 5 - MTBR 123.800; 6 - USP 5-19. Análise de Hayman para um dialelo 6 × 6 com 15 cruzamentos $F_{2}$. Soja, semeadura em 09/11/98 (ESALQ) e 24/11/98 (Anhembi). Piracicaba-SP 
7 Regressão de Wi sobre Vi para o caráter produtividade de óleo (PO). Parentais: 1-Hartwig; 2-Conquista; 3- USP 1-11; 4 - USP 2-16; 5 - MTBR 123800; 6 - USP 5-19. Análise de Hayman para um dialelo $6 \times 6$ com 15 cruzamentos $F_{2}$. Soja, semeadura em 09/11/98 (ESALQ) e 24/11/98 (Anhembi). Piracicaba-SP 


\section{LISTA DE TABELAS}

Página

1 Genealogia dos parentais envolvidos nos cruzamentos dialélicos $6 \times 6$.

2 Esquema da análise de variância individual em blocos ao acaso e respectivas esperanças matemáticas dos quadrados médios.

3 Esquema da análise de variância conjunta em blocos ao acaso e as respectivas esperanças matemáticas dos quadrados médios

4 Esquema da análise de variância e covariância e esperança de quadrado médio e produto médio para o cálculo das correlações.

5 Análise individual (ESALQ): Quadrados médios e significâncias obtidas na análise de variância individual, média geral, coeficiente de variação (CV) e de determinação $\left(R^{2}\right)$ referentes aos caracteres número de dias para florescimento (NDF), altura da planta no florescimento (APF), número de dias para maturidade (NDM), altura da planta na maturidade (APM), valor agronômico (VA), produtividade de grãos (PG), porcentagem de óleo (\%OL) e produtividade de óleo (PO). Soja, semeadura em 09/11/98. Piracicaba-SP

6 Análise individual (Anhembi): Quadrados médios e significâncias obtidas na análise de variância individual, média geral, coeficiente de variação (CV) e de determinação $\left(R^{2}\right)$ referentes aos caracteres número de dias para florescimento (NDF), altura da planta no florescimento (APF), número de dias para maturidade (NDM), altura da planta na maturidade (APM), valor agronômico (VA), produtividade de grãos (PG), porcentagem de óleo (\%OL) e produtividade de óleo (PO). Soja, semeadura em 24/11/1998. Piracicaba-SP.

7 Análise conjunta: Quadrados médios e significâncias obtidas na análise de variância conjunta, média geral, coeficiente de variação (CV) e de determinação $\left(R^{2}\right)$ referentes aos caracteres número de dias para florescimento (NDF), altura da planta no florescimento (APF), número de dias para maturidade (NDM), altura da planta na maturidade (APM), valor agronômico (VA), produtividade de grãos (PG), porcentagem de óleo (\%OL) e produtividade de óleo (PO). Soja, semeadura em 09/11/98 (ESALQ) e 24/11/1998 (Anhembi), Piracicaba-SP 
8 Médias de tratamentos (ESALQ): comparação pelo teste de Scott-Knott entre médias de 72 observações de 21 tratamentos, referentes aos caracteres número de dias para florescimento (NDF), altura da planta no florescimento (APF), número de dias para maturidade (NDM), altura da planta na maturidade (APM), valor agronômico (VA), produtividade de grãos (PG), porcentagem de óleo (\%OL) e produtividade de óleo (PO). Soja, semeadura em 09/11/1998. Piracicaba-SP.

9 Médias de tratamentos (Anhembi): comparação pelo teste de Scott-Knott entre médias de 72 observações de 21 tratamentos, referentes aos caracteres número de dias para florescimento (NDF), altura da planta no florescimento (APF), número de dias para maturidade (NDM), altura da planta na maturidade (APM), valor agronômico (VA), produtividade de grãos (PG), porcentagem de óleo (\%OL) e produtividade de óleo (PO). Soja, semeadura em 24/11/1998. Piracicaba-SP.

10 ESALQ: correlações fenotipicas $\left(r_{F}\right)$, genotípicas $\left(r_{G}\right)$ e ambientais $\left(r_{E}\right)$ entre os caracteres número de dias para florescimento (NDF), altura da planta no florescimento (APF), número de dias para maturidade (NDM), altura da planta na maturidade (APM), valor agronômico (VA), produtividade de grãos (PG), porcentagem de óleo $(\% \mathrm{OL})$ e produtividade de óleo (PO), para cruzamentos $F_{2}$ (acima da diagonal) e parentais (abaixo da diagonal). Esquema dialélico $6 \times 6$ com 15 cruzamentos $F_{2}$.Soja, semeadura em 09/11/98. Piracicaba-SP.

11 Anhembi: Correlações fenotípicas $\left(r_{F}\right)$, genotípicas $\left(r_{G}\right)$ e ambientais $\left(r_{E}\right)$ entre os caracteres número de dias para florescimento (NDF), altura da planta no florescimento (APF), número de dias para maturidade (NDM), altura da planta na maturidade (APM), valor agronômico (VA), produtividade de grãos (PG), porcentagem de óleo $(\% \mathrm{OL})$ e produtividade de óleo (PO), para cruzamentos $\mathrm{F}_{2}$ (acima da diagonal) e parentais (abaixo da diagonal). Esquema dialélico $6 \times 6$ com 15 cruzamentos $F_{2}$.Soja, semeadura em 24/11/1998. Piracicaba-SP.

12 Meia tabela dialélica reunindo os parentais na diagonal e os cruzamentos $F_{2}$ acima da diagonal. 
13 Análise de variância pelo método 2, modelo misto $B$ de Griffing (1956a).

14 Análise de variância conjunta pelo método 2, modelo misto $B$ de Griffing (1956a).

15 Quadrados médios para capacidade geral de combinação (CGC) e capacidade especifica de combinação (CEC), relação entre CGC e CEC e média dos quadrados médios dos efeitos de CGC e CEC para os caracteres número de dias para florescimento (NDF), altura da planta no florescimento (APF), número de dias para maturidade (NDM), altura da planta na maturidade (APM), valor agronômico (VA), produtividade de grãos $(P G)$, porcentagem de óleo (\%OL) e produtividade de óleo (PO). Dialélico $6 \times 6$ com 15 cruzamentos F2. Soja, semeadura em 09/11/98 (ESALQ) e 24/11/98 (Anhembi),Piracicaba-SP.

16 Análise dialélica conjunta, referentes aos caracteres número de dias para florescimento (NDF), altura da planta no florescimento (APF), número de dias para maturidade (NDM), altura da planta na maturidade (APM), valor agronômico (VA), produtividade de grãos ( $P G)$, porcentagem de óleo (\%OL) e produtividade de óleo (PO). Dialélico $6 \times 6$ com 15 cruzamentos F2. Soja, semeadura em 09/11/98 (ESALQ) e 24/11/1998 (Anhembi), Piracicaba-SP

17 Estimativas dos efeitos da capacidade geral de combinação $\left(\hat{g}_{i}\right)$ individual e conjunta e sua interação com locais ( $\left(\hat{g}_{i k}\right)$, com os respectivos erros padrões entre os efeitos $g_{i} e$ as respectivas médias dos parentais para os caracteres número de dias para florescimento (NDF), altura da planta no florescimento (APF), número de dias para maturidade (NDM), altura da planta na maturidade (APM), valor agronômico transformado para $\sqrt{x+0.5}$ $\left(N A^{1}\right)$, produtividade de grãos (PG), porcentagem de óleo (\%OL) e produtividade de óleo (PO). Dialélico $6 \times 6$ com 15 cruzamentos $F_{2}$.. Soja, semeadura em 09/11/98 (ESALQ) e 24/11/1998 (Anhembi), Piracicaba-SP

18 Estimativas dos efeitos da capacidade especifica de combinação dos parentais com eles próprios ( $\hat{S}_{i i}$ ) individual e conjunta e sua interação com locais ( $\left(\hat{S}_{i i k}\right)$ com os respectivos erros padrões para os caracteres número de dias para florescimento (NDF), altura da planta no florescimento (APF), número de dias para maturidade (NDM), altura da planta na maturidade 
de grãos (PG), porcentagem de óleo (\%OL) e produtividade de óleo (PO). Dialélico $6 \times 6$ com 15 cruzamentos $F_{2}$.. Soja, semeadura em 09/11/98 (ESALQ) e 24/11/1998 (Anhembi), Piracicaba-SP.

19 Estimativas dos efeitos da capacidade especifica de combinação $\left(\hat{\mathrm{s}}_{\mathrm{ij}}\right) \mathrm{com}$ os respectivos erros padrões para os caracteres número de dias para florescimento (NDF), altura da planta no florescimento (APF), número de dias para maturidade (NDM), altura da planta na maturidade (APM), valor agronômico (VA), produtividade de grãos (PG), porcentagem de óleo (\%OL) e produtividade de óleo (PO). Dialélico $6 \times 6$ com 15 cruzamentos $F_{2}$. Soja, semeadura em 09/11/98(ESALQ) e 24/11/98 (Anhembi), Piracicaba-SP.

20 Estimativas da interação do efeito da capacidade específica de combinação por locais $\left(\left.\right|_{s_{j k}}\right)$, com os respectivos erros padrões para os caracteres número de dias para florescimento (NDF), altura da planta no florescimento (APF), número de dias para maturidade (NDM), altura da planta na maturidade (APM), valor agronômico (VA), produtividade de grãos $(\mathrm{PG})$, porcentagem de óleo (\%OL) e produtividade de óleo (PO). Dialélico $6 \times 6$ com 15 cruzamentos $F_{2}$. Soja, semeadura em 09/11/98 (ESALQ) e 24/11/98 (Anhembi), Piracicaba-SP

21 Análise genética pelo Método de Hayman: Teste do modelo $(b=1)$, estimativas de componentes de variância aditiva (D) e dominante $\left(\mathrm{H}_{1} \mathrm{e}\right.$ $\mathrm{H}_{2}$ ), distribuição das freqüências alélicas nos parentais $(F)$, grau médio de dominância (gmd), proporção de alelos dominantes e recessivos (d/r), simetria $(\mu \mathrm{v}=0,25)$, coeficiente de determinação genotipica no sentido amplo $\left(h^{2}{ }_{a}\right)$ e restrito $\left(h_{r}^{2}\right)$ referentes aos caracteres número de dias para florescimento (NDF), altura da planta no florescimento (APF), número de dias para maturidade (NDM), altura da planta na maturidade (APM), produtividade de grãos (PG), porcentagem de óleo (\%OL) e produtividade de óleo (PO). Soja, semeadura em 09/11/98 (ESALQ) e 24/11/98 (Anhembi). Piracicaba-SP. 


\title{
ANÁLISE DIALÉLICA ENVOLVENDO GENÓTIPOS PARENTAIS DE SOJA RESISTENTES AO NEMATÓIDE DE CISTO
}

\author{
Autora: ÂNGELA CELIS DE ALMEIDA LOPES \\ Orientador: Prof. Dr. NATAL ANTONIO VELLO
}

\section{RESUMO}

Esta tese teve como objetivo principal avaliar o potencial de cruzamentos entre parentais resistentes ao nematóide de cisto da soja (NCS) para o melhoramento genético, principalmente para produtividade de grãos e de óleo mediante estudos de interações de genótipos com ambientes, correlações entre caracteres, ação gênica e capacidade combinatória. Foram utilizados seis genótipos parentais de soja, reunindo cultivares comerciais, exóticos e linhagens experimentais: (1) Hartwig, (2) Conquista, (3) USP 1-11, (4) USP 2-16, (5) MTBR 123.800, (6) USP 5-19. Esses parentais foram selecionados de acordo com os objetivos de produtividade de grãos, tolerância ao fotoperíodo, e resistência a doenças. A pesquisa incluiu 21 tratamentos, seis parentais e suas 15 combinações dialélicas em $F_{2}$, avaliadas em experimentos em blocos ao acaso com seis repetições por local (ESALQ e Anhembi). A parcela foi representada por 12 covas de plantas individuais espaçadas de $0,80 \mathrm{~m} \times 0,80 \mathrm{~m}$. Os caracteres avaliados foram: número de dias para o florescimento (NDF), maturidade (NDM), altura da planta no florescimento (APF) e na maturidade (APM), valor agronômico (VA), produtividade de grãos $(\mathrm{PG})$, porcentagem de óleo nas sementes (\%OL) e produtividade de óleo (PO). Os resultados permitiram concluir que: a) os parentais e a geração $F_{2}$ apresentaram variabilidade para todos os caracteres; b) os cruzamentos Hartwig x USP 1-11 (1 × 3), Conquista x USP 1-11 $(2 \times 3)$, Conquista $\times$ USP 2-16 ( $2 \times 4$ ) e USP 2-16 x MTBR $123.800(4 \times 5)$ destacaram-se nos dois locais; c) o local Anhembi foi mais favorável para PG; d) a interação genótipos $\times$ locais $(G \times L)$ foi um forte componente da variação fenotipica; e) as correlações genotipicas foram maiores que as 
fenotipicas e de ambiente nos dois locais; f) tanto a capacidade geral de combinação (CGC) quanto a capacidade especifica de combinação (CEC) foram importantes e interagiram com locais; g) as análises numéricas e gráficas detectaram sobredominância para a maioria dos caracteres, porém a variância aditiva também se revelou importante; $h$ ) os coeficientes de determinação genotipica no sentido amplo $\left(\mathrm{h}^{2} \mathrm{a}\right)$ foram altos para os caracteres, enquanto no sentido restrito $\left(h^{2}\right)$ foram muito variáveis de um local para outro. 


\title{
DIALLEL ANALYSIS AMONG SOYBEAN PARENTS WITH RESISTANCE TO CYST NEMATODE
}

\author{
Author: ÂNGELACELIS DE ALMEIDALOPES \\ Adviser: Prof. Dr. NATAL ANTONIO VELLO
}

\section{SUMMARY}

This research aimed to evaluate the breeding potential, mainly for seed and oil yield, of soybean diallel crosses among parents with resistance to soybean cyst nematode. This objective was reached through genotype $x$ environment interaction, correlations among characters, genetic action and combining ability. Six soybean genotypes were used as parents, including commercial cultivars, exotic genotypes and experimental lines: (1) Hartwig, (2) Conquista, (3) USP 1-11, (4) USP 2-16, (5) MTBR 123.800, (6) USP 5-19. The 21 treatments, six parents and their 15 diallel combinations in $F_{2}$, were evaluated in two experiments designed in complete randomized block, with six replications in to lacalities (ESALQ and Anhembi). The experimental plot was represented by 12 hills of individual plants spaced $0.80 \mathrm{~m} \times 0.80 \mathrm{~m}$. The number of days to flowering (NDF) and maturity (NDM), plant height at flowering (APF) and at maturity (APM), agronomic value (NA), seed yield (PG), oil percentage in the seeds (\%OL) and oil yield (PO) were evaluated as traits. The results allowed to conclude that: a) the parents and the crosses presented variability for all traits; b) the crosses Hartwig $\times$ USP 1-11 (1 $\times 3)$, Conquista $\times$ USP 1-11 $(2 \times 3)$, Conquista $\times$ USP 2-16 (2x 4) and USP 2-16 x MTBR 123.800 (4 x 5) exceeded in two localities; c) Anhembi was more favorable than ESALQ for PG; d) the genotype $x$ locality interaction $(G \times L)$ was a important component of the phenotypic variation; e) genotypic correlations were larger than phenotypic and environmental correlations in the two localities; f) general and specific combinig abilities were 
importants and they interacted with localities; g) the Hayman's numeric and graphic analyses detected overdominance for most of the characters, however, the addictive genetic action was also important; $h)$ the broad sense $\left(h^{2}\right)$ estimates of the coefficient of genotypic determination were high, for all traits, while narrow sense $\left(h^{2} r\right)$ estimates were very variable between localities, showing again the influence of the genotype $x$ locality interaction. 


\section{INTRODUÇÃO}

O objetivo básico de um programa de melhoramento de uma espécie autógama é obter linhagens de alto valor agronômico. Nesse processo algumas etapas são de primordial importância, tais como: a seleção de parentais, identificação dos melhores cruzamentos, avanço de gerações sem grandes perdas das combinações gênicas desejáveis e identificação, com 0 máximo rigor experimental possivel, das linhagens superiores. As duas primeiras fases geralmente não são realizadas com rigor, devido a não se querer gastar tempo avaliando parentais e ao reduzido número de sementes disponiveis nas gerações iniciais. Entretanto é muito importante obter estimativas de parâmetros genéticos que possibilitem o conhecimento sobre a concentração dos alelos favoráveis nos parentais e identificar as combinações hibridas mais promissoras. Dentro deste contexto, os cruzamentos dialélicos se destacam porque fornecem informações sobre os parentais e sobre as gerações iniciais.

Através do estudo dos cruzamentos dialélicos, pode-se entender melhor a natureza da ação gênica presente em caracteres de importância para agricultura. Os cruzamentos dialélicos ainda fornecem estimativas da capacidade geral de combinação (CGC) e da capacidade especifica de combinação (CEC). A CGC caracteriza o comportamento do parental em várias combinações hibridas, enquanto CEC caracteriza o comportamento de combinações hibridas especificas em relação à média dos parentais. Assim, a CGC está associada principalmente a genes de efeitos aditivos, embora também dependa de genes com dominância e da epistasia aditiva $x$ aditiva. Já a CEC depende basicamente de genes de efeitos dominantes e epistáticos do tipo dominante $x$ dominante (Sprague \& Tatum, 1942).

As populações formadas são avançadas através das gerações por vários métodos nos quais, devido as características da biologia floral da espécie, há uma forte predominância de autofecundação, levando a obtenção de progênies endogâmicas. As avaliações e seleções durante um grande número de gerações, geralmente até a geração $F_{7}$, têm 0 inconveniente de consumir bastante tempo e grande quantidade de recursos (Burton, 1997). Portanto, será mais 
vantajoso se a seleção pudesse ser realizada o mais cedo possivel, em gerações iniciais, de modo que somente os melhores genótipos fossem mantidos no programa (Rana \& Gupta, 1993). Segundo Triller \& Toledo (1996), as estimativas do potencial genético de cruzamentos são de grande importância em qualquer programa de melhoramento e quando essa predição é feita no começo, menos materiais promissores podem ser descartados antes da condução de testes de produtividade, os quais normalmente são bastante caros. Nos últimos anos entretanto, os melhoristas têm investido tempo e esforço no desenvolvimento de metodologias eficientes para avaliação e seleção em gerações precoces (Roupakias et al. 1997).

Com isso se consegue reduzir, logo nas gerações iniciais, problemas de incompatibilidade híbrida, diferenças na capacidade de combinação ou até mesmo ocorrência de recombinantes inferiores. Deste modo, é melhor testar e identificar populações ou famílias em gerações iniciais, descartando-se aquelas que possuam características indesejáveis tais como suscetibilidade a doenças, produtividade muito baixa e valor de cultivo e uso reduzido). No final, consegue-se direcionar todo 0 trabalho somente para as populações que realmente tiveram destaque desde o início do programa, economizando tempo e recursos.

Este trabalho faz parte do Programa de Soja do Setor de Genética Aplicada às Espécies Autógamas do Instituto de Genética da Escola Superior de Agricultura "Luiz de Queiroz", da Universidade de São Paulo. Esta pesquisa teve os seguintes objetivos: avaliar o potencial genético e a capacidade de combinação entre parentais de soja previamente selecionados para resistência ao nematóide de cisto da soja (NCS, Heterodera glycines), o parasita mais prejudicial à cultura da soja e de ocorrência recente, mas amplamente disseminado no Brasil. Pretendeu-se, assim, avaliar a possibilidade de se reunir em um mesmo genótipo os genes de resistência ao NCS e os genes para adaptação e produtividade de grãos. Um outro objetivo foi estimar parâmetros genéticos para caracteres de importância agronômica na cultura da soja. 


\section{REVISÃO DE LITERATURA}

\subsection{Histórico e perspectivas da cultura da soja}

A soja (Glycine max (L.) Merrill) é uma espécie autógama, cuja taxa de cruzamento natural varia de 0,5 a 1\%. O centro da China mais precisamente a região do vale do Rio Amarelo é considerado seu Centro de Origem. Hymowitz (1970), baseado em estudos lingüisticos, históricos e geográficos, propôs que a soja foi domesticada na metade oriental do Norte Chinês (centro primário de diversidade), durante ou talvez antes da dinastia Shang (1700-1100 A. C.). A soja, juntamente com o arroz, o trigo, a cevada e o milheto, foi considerada um dos cinco grãos sagrados essenciais para a existência da civilização Chinesa. A partir dai, a soja foi disseminada para toda a China. Por volta do primeiro século até o século XVI, ela foi introduzida no Japão, Indonésia, Filipinas, Vietnã, Tailândia, Norte da Índia e Nepal. Estas regiões são consideradas centros secundários de diversidade da soja, pois muitas raças locais foram desenvolvidas nestes paises (Hymowitz, $1990^{1}$ citado por Singh \& Hymowitz, 1999).

No final do século XVI e por todo século XVII, missionários e marinheiros levaram a soja da China e Japão para a Europa, mas a soja não teve sucesso na agricultura européia. Em 1765, a soja foi introduzida da China para a América do Norte, no estado da Geórgia. Após está data, cientistas, comerciantes e expedições militares, entre outros, fizeram novas introduções da soja da China para os Estados Unidos. Somente no período de 1860 a 1900 é que se iniciaram pesquisas agrícolas nos Estados Unidos. Neste periodo, foi criado um órgão oficial responsável pela introdução de sementes e plantas estrangeiras, dando inicio à introdução de um grande número de introduções de soja proveniente dos paises asiáticos. Atualmente, nos bancos de germoplasma de soja são conservados mais de 100.000 acessos. No entanto, o valor comercial da soja só foi reconhecido no começo do século 20 , através dos estudos de Osborn \& Mendel (1917), que demonstraram experimentalmente que ratos alimentados com uma dieta a base de

1. HYMOWITZ, T. Soybeans: the sucess story. In: Advances in New Crops: Proceedings of the First Syr-casium on New Crops: Research, Development, Economics. p. 159-163, 1990 
soja crescem mais do que aqueles com uma dieta pobre em soja. Este estudo resultou no estabelecimento do processo industrial da soja nos EUA.

No Brasil, a primeira noticia sobre a soja data de 1882, no estado da Bahia. Em São Paulo, foi cultivada pela primeira vez em 1892, no Instituto Agronômico de Campinas. Já no Rio Grande do Sul, a primeira notícia data de 1901. No estado do Paraná, seu cultivo foi iniciado em 1954 , mas somente nos anos 70 é que realmente ocorreram grandes aumentos na área cultivada com a soja. Entre meados dos anos 80 e 90, foi significativo o crescimento da cultura da soja na região do Brasil-Central, envolvendo os estados do Mato Grosso do Sul, Mato Grosso e Goiás, destacando-se o estado do Mato Grosso como maior produtor de soja em 99/2000. Atualmente, a soja é cultivada em praticamente todo território nacional, destacando-se a região Norte como a fronteira agricola mais nova para cultivo da soja, inclusive chegando até paises que fazem fronteira com o Brasil, como é o caso da Bolivia e do Paraguai.

O histórico antes relatado mostra a grande importância da soja para o Brasil, valendo ressaltar que não somente pela sua expressão no País, mas também por suas características enquanto cultura alimentar e industrial. Sua semente é rica em proteinas (variando de 30 a 48\%, com média de 40\%) e óleo (variando de 13-22\%, com média de $20 \%$ ). A soja lidera a classificação das espécies produtoras de óleo, seguida pelo algodão, amendoim, girassol, colza, coco e semente de palmeira (dendê) e é cultivada mundialmente, tendo os Estados Unidos como principal produtor, seguidos pelo Brasil, Argentina e China (Singh \& Hymowitz, 1999 ).

As perspectivas quanto ao desenvolvimento da cultura da soja são muito boas, no entanto há algumas limitações, podendo-se destacar a dificuldade para a obtenção de ganhos de produtividade e para obtenção de resistência a algumas doenças. Entretanto, no grupo das leguminosas, a soja é a única com aumentos consistentes na produtividade, graças aos trabalhos de melhoramento realizados nos EUA e Brasil (Ranalli \& Cubero, 1997), os quais conseguiram aumento de aproximadamente $18,80 \mathrm{~kg} / \mathrm{ha}$ anualmente no periodo de $1900-1980$, um incremento de 1,5tha em 80 anos. Embora a baixa produtividade possa ser um fator limitante, tem-se os recursos genéticos e a habilidade dos melhoristas para se conseguir um aumento substancial na produtividade das espécies leguminosas (Singh \& Hymowitz, 1999).

Um outro ponto limitante e que tem reflexo direto, principalmente no estabelecimento de patamares de produtividade, é a realização, pelos melhoristas, de hibridação apenas dentro do 
GP-1 (Conjunto Gênico Primário, constituído por Glycine max e Glycine soja), além da do fato dos parentais serem restrito aos cultivares altamente produtivos, cujas sementes possuem alto teor de óleo e ou proteína. A partir disto, vários estudos foram realizadas nos EUA e também no Brasil. O primeiro deles foi desenvolvido por Delannay et al. (1983), que traçaram as genealogias de 158 cultivares de soja do Canadá e Estados Unidos e descobriram que os ancestrais do germoplasma cultivado era constituido de 50 introduções de plantas (Pl's).

Em seguida, Gizlice et al. (1993) examinaram as genealogias dos cultivares de soja obtidos a partir de 1947 até 1988 e concluíram que menos de 15 ancestrais constituem a maior porção da base genética da soja cultivada nos Estados Unidos. Em outra análise, Gizlice et al. (1994) observaram que somente seis ancestrais constituem mais da metade da base genética da soja norte-americana. Sneller (1994) estimou um parentesco de 90 a $92 \%$ entre as linhagens elites de soja do setor público e privado cultivadas nas regiões Norte e Sul, podendo as mesmas serem traçadas para apenas 12 ancestrais. Gizlice et al. (1996) encontraram valores de coeficiente de parentesco de 0,233 e 0,261 entre linhagens do Norte e Sul dos Estados Unidos. Os autores ressaltaram ainda que os melhoristas de soja freqüentemente hibridizam parentais provenientes de um mesmo grupo de maturação, ao invés de usar parentais que diferem em pelo menos um grupo de maturação. Estes estudos revelaram que os cultivares de soja norteamericanos têm uma base genética extremamente estreita.

Baseado nesses trabalhos, Cui et al. (2000) quantificaram a base genética da soja na China por meio do coeficiente de parentesco e compararam com a dos Estados Unidos e Canadá. Essa comparação mostrou que a base genética da soja chinesa é mais ampla que a dos Estados Unidos e Canadá e que ela continua se expandindo com o tempo, o oposto do que está ocorrendo nos Estados Unidos e Canadá. A análise mostrou ainda que 35 ancestrais contribuíram com $50 \%$ e 339 com $90 \%$ dos genes para os cultivares de soja chineses, enquanto que somente 5 e 26 ancestrais contribuiram respectivamente com iguais porcentagens para a base genética dos cultivares de soja americanos e canadenses. Após essa constatação, os autores destacaram a necessidade do uso, por parte dos programas de melhoramento dos Estados Unidos e Canadá, de cultivares chineses, principalmente por causa de sua base genética ampla e por estarem isolados dos cultivares americanos. Essa estratégia tem dado bons resultados na China, resultando em ganhos genéticos na produtividade, teores de óleo e proteína 
e resistência a doenças quando são empregados como parentais os cultivares norte-americanos, comprovando na prática, a importância do uso de recursos genéticos exóticos no melhoramento.

Existe um reduzido número de trabalhos sobre a base genética dos cultivares de soja brasileiros, no entanto sabe-se que a mesma também é estreita. Na tentativa de estudar melhor 0 referido assunto, Hiromoto \& Vello (1986) avaliaram a base genética de 74 cultivares de soja e constataram que apenas 11 ancestrais representavam essa base e que estes eram responsáveis por $89 \%$ do conjunto gênico dos cultivares brasileiros. Posteriormente, Vello et al. (1988) estudaram 69 cultivares de soja, cujos coeficientes de parentesco variaram de 0 a 1; os autores verificaram que entre 11 e 15 diferentes genótipos deram origem a esses cultivares, concluindo que 0 tamanho efetivo da população era baixo. Um outro trabalho realizado por Bonato (2000) avaliou a similaridade genética com marcadores AFLP entre 317 cultivares de soja, liberadas no Brasil no período de 1962 a 1998. Os resultados mostraram que esses cultivares apresentam alta similaridade genética, tendo sido detectado agrupamentos de cultivares formados de acordo com o esperado através da genealogia dos mesmos.

A causa da base estreita dos cultivares de soja pode ser atribuida ao uso repetido dos mesmos parentais ou de suas melhores progênies com pouca incorporação dos genótipos exóticos, e também as hibridações estarem restritas a um único grupo de maturação. Por outro lado, a principal conseqüência do estreitamento da base genética é a redução da variabilidade genética $e$, consequentemente, 0 aumento da vulnerabilidade genética a diferentes estresses abióticos e bióticos, que pode limitar o ganho genético para características métricas, como produtividade (Singh \& Hymowitz, 1999). Para comprovar tal fato, destaca-se o trabalho de Kisha et al. (1997), que mostrou uma associação positiva da variação genética entre produtividade e outras características agronômicas em populações de soja cujos parentais eram geneticamente distantes, ressaltando que o aumento da diversidade genética da soja é um importante objetivo dentro de um programa de melhoramento. No entanto, de acordo com Rasmusson \& Phillips (1997), a redução da diversidade genética no germoplasma não compromete nem limita futuros ganhos genéticos, já que mecanismos tais como amplificação gênica, elementos transponiveis ou transposiveis, interações alélicas e epistasia, juntamente com a recombinação, geram constantemente nova diversidade genética no germoplasma elite empregado nos programas de melhoramento. Apesar de tudo isso não se pode esquecer que os melhoristas fizeram grandes 
conquistas e o caso da soja pode servir como exemplo, sendo cultivada atualmente em todo 0 Brasil.

Pode-se acrescentar ainda que é bastante clara a preocupação com a estreita base genética da soja e que através do conhecimento deste fato devem-se buscar saídas de forma a minimizar e quem sabe evitar o seu estreitamento dentro das diferentes atividades que englobam um programa de melhoramento.

\subsection{Etapas essenciais no programa de melhoramento}

A escolha dos parentais é crucial para o sucesso de um programa de melhoramento. Os parentais devem ser escolhidos visando maximizar as mudanças, de forma que a população gerada seja geneticamente variável para as características que estão sendo selecionadas. Normalmente, no melhoramento por hibridação, o objetivo principal é a associação, em um mesmo indivíduo, de duas ou mais características favoráveis que estão presentes em linhagens diferentes. Portanto, realizando cruzamentos entre esses indivíduos, é gerada uma população com variabilidade genética suficiente na qual será praticada seleção, visando a obtenção de uma ou mais linhagens que reunam as características de interesse (Allard, 1971; Fehr, 1987). Contudo, para atingir esse objetivo, o melhorista se depara com algumas dificuldades: qual critério a ser utilizado na seleção dos parentais a serem cruzados; qual a melhor forma de se realizar as combinações dos parentais; e qual método deve ser empregado na condução das populações segregantes. Sendo assim, a escolha dos parentais é uma das etapas que demanda o emprego de metodologias que tornem o processo mais eficiente. Dai infere-se que a escolha dos parentais para hibridação é uma das etapas mais importantes num programa de melhoramento.

Um dos pontos principais a ser considerado é o conjunto gênico. 0 ideal é escolher parentais distantes entre si. Se o objetivo é alta produtividade, então deve-se eleger linhagens ou cultivares não aparentados. Este procedimento deve ser adotado para outras características, tais como resistência a doenças e pragas. Caso seja necessário escolher parentais não-adaptados com o objetivo de introduzir genes para uma característica particular, então deve-se usar um germoplasma com o menor número possível de características indesejáveis. As progênies $F_{1}$ 
podem ser avaliadas ou autofecundadas por várias gerações e estudadas a priori, fator que permitirá o aumento das sementes necessárias para os testes de campo.

Após esta etapa, as linhagens são avaliadas ao nivel de campo e laboratório. 0 desempenho também é estudado em diferentes condições ambientais e as melhores linhagens podem ser lançadas como cultivares ou podem ainda ser usadas como parentais em novos ciclos de cruzamentos, sendo necessária maior atenção para diversidade genética e ampliação da base. Pesquisas futuras devem enfatizar o desenvolvimento de populações, observando a origem dos parentais e o seu desempenho com relação a outros cultivares, considerando diferentes ambientes. É necessário também o planejamento e o desenvolvimento de esquemas de seleção que incorporem um ciclo mais rápido de identificação, seleção e recombinação de linhagens elites, além do manejo da interação genótipo $x$ ambiente $e$ alocação de recursos para testes preliminares e avançados (Burton, 1997).

Verifica-se, então, que a escolha criteriosa dos parentais que irão ser utilizados nos cruzamentos é muito importante $e$, quando bem feita, possibilita que se obtenha populações com ampla variabilidade genética. Isso se consegue quando se cruzam parentais divergentes e com um bom padrão genético. A divergência genética pode ser avaliada por várias técnicas quantitativas, destacando-se os dialelos.

Dentre os vários métodos utilizados para a escolha dos parentais, pode-se citar aqueles que se baseiam no desempenho de suas progênies, destacando-se os dialelos. Além disso, os cruzamentos dialélicos auxiliam na escolha de genitores a partir de seus valores genéticos e, principalmente, na capacidade desses parentais se combinarem em hibridos que produzam populações segregantes promissoras. Este método ainda torna possivel conhecer o controle genético dos caracteres, orientando assim 0 melhorista, na condução das populações segregantes e na seleção (Vencovsky \& Barriga, 1992; Ramalho et al., 1993; Cruz \& Regazzi, 1994). Embora os cruzamentos dialélicos sejam um método que permite a escolha de populações segregantes, sua principal limitação está na realização das hibridações, sobretudo quando estão envolvidos muitos parentais, onde os cruzamentos são dificeis e produzem um número reduzido de sementes, como ocorre na cultura da soja. Outra limitação seria testar um grande número de cruzamentos, cada um deles com um certo número de progênies, em diferentes ambientes (Vello \& Pires, 1992). 


\subsection{Análise dialélica e sua importância}

Como já relatado anteriormente, dentro de um programa de melhoramento envolvendo hibridações, a seleção de parentais é uma das etapas mais importantes. Para isso, é preciso obter estimativas de parâmetros genéticos que possibilitem 0 conhecimento sobre a concentração dos alelos favoráveis, após recombinação, além de analisar as combinações hibridas mais promissoras. Dentro deste contexto, os cruzamentos dialélicos são de fundamental importância.

A expressão dialelo refere-se a todas as possibilidades de hibridações, realizadas aos pares, dentro de um grupo de parentais. O conceito de cruzamento dialélico foi apresentado por Griffing (1956b) como o conjunto das $p^{2}$ combinações híbridas possiveis de serem obtidas a partir de $p$ genitores. De acordo com Hallauer \& Miranda Filho (1988), os esquemas e as análises de cruzamentos dialélicos têm sido desenvolvidas com parentais cujas bases genéticas variam desde linhagens puras (com base estreita, como é o caso da soja), até variedades com ampla base genética.

Do ponto de vista teórico, através do estudo dos cruzamentos dialélicos, pode-se entender melhor a natureza da ação gênica presente em caracteres de importância para a agricultura (Kempthorne, 1956). Já do ponto de vista aplicado, os cruzamentos dialélicos fornecem estimativas da capacidade geral de combinação (CGC) e da capacidade específica de combinação (CEC). A primeira caracteriza o comportamento do parental em várias combinações hibridas, enquanto a segunda caracteriza o comportamento de combinações híbridas especificas em relação à média dos parentais. Assim, a CGC está associada principalmente a genes de efeitos aditivos, mas também dominantes e epistáticos do tipo aditivo $\mathrm{x}$ aditivo; já a CEC depende basicamente de genes de efeitos dominantes e epistáticos do tipo dominante $x$ dominante (Sprague \& Tatum, 1942).

Do ponto de vista estatístico, os cruzamentos dialélicos podem ser analisados segundo os modelos fixo e aleatório. No primeiro, os parentais são escolhidos e não representam uma amostra de uma população. Isso implica que as conclusões somente são válidas para o material genético estudado, não podendo ser extrapoladas ou generalizadas. Já no aleatório, os parentais 
são amostras de uma população de referência (por exemplo uma geração $F_{2}$ ) e as conclusões tiradas em relação aos parâmetros da população.

Em programas de melhoramento, 0 conhecimento dos componentes da capacidade de combinação é de relevante importância na escolha dos parentais divergentes envolvidos em esquemas de cruzamentos, sobretudo quando se deseja desenvolver linhagens superiores e identificar hibridos promissores (Melo, 1987).

O grande interesse pelo assunto de cruzamentos dialélicos fez com que os conhecimentos evoluíssem, sendo desenvolvidos vários métodos de análise dialélica. Dentre estes, destacam-se os propostos por Hayman (1954a,b), que fornecem informações a respeito do mecanismo básico de herança do caráter estudado, dos valores genéticos dos parentais e do limite de seleção; o método de Griffing (1956b) que estima os efeitos da capacidade geral e especifica de combinação; e o de Gardner \& Eberhart (1966), que separa a heterose em seus diversos componentes.

De acordo com Cruz \& Regazzi (1994), existem cinco tipos de cruzamentos dialélicos:

1. Dialelos completos ou de meia tabela, podendo envolver além da análise de hibridos $F_{1}$ 's, os genitores, os hibridos reciprocos e também a geração $\mathrm{F}_{2}$;

2. Dialelos parciais, envolvendo a análise dos genitores (em dois grupos) e dos hibridos entre genitores de grupos diferentes;

3. Dialelos circulantes e dialelos incompletos;

4. Dialelos desbalanceados, quando há número desigual de repetição para os tratamentos.

Dentre os cruzamentos dialélicos, o completo é bastante usado, podendo-se ter variações, sendo a que envolve os parentais e seus cruzamentos sem os reciprocos uma das mais utilizadas. Isso se justifica pela dificuldade de obtenção de número suficiente de sementes hibridas em cada cruzamento e principalmente porque o efeito materno, que só pode ser detectado com a inclusão dos cruzamentos reciprocos, não é a principal causa da variação da maioria dos caracteres (Ramalho et al., 1993).

Através dos métodos de análise dialélica, pode-se também obter informações adicionais pelas estimativas de variâncias genética e ambiental dentro de cada tratamento. Em relação a variância ambiental, fazem-se avaliações de plantas individuais nos parentais e nas gerações $F_{1}$. Já as avaliações dentro de populações segregantes permitem estimar variâncias 
genéticas, pois as plantas que constituem cada população, como $F_{2}$ por exemplo, possuem genótipos diferentes. Quando elas são avaliadas individualmente, observam-se diferenças provenientes dos vários genótipos e também da influência dos fatores ambientais, possibilitando isolar a variância genética intrapopulacional.

O emprego da $F_{2}$ ou de gerações mais avançadas para o estudo através de dialelos também é criticado, principalmente porque diferentes populações $F_{2}$ não apresentam as mesmas segregações, além de requererem a avaliação de populações grandes de cada uma delas (Arunachalam, 1976). No entanto, existem pontos favoráveis, uma vez que em $F_{2}$ pode-se trabalhar com um maior número de plantas, até mesmo, para estimar heterose, pois maiores populações $F_{2}$ podem ser conduzidas, fornecendo estimativas mais reais. Outro aspecto favorável ao emprego da $F_{2}$ é a possibilidade de estimar a variabilidade genética dentro de cada uma, o que constitui grande auxilio na escolha das populações mais promissoras para a seleção, especialmente por permitir discriminar populações de médias semelhantes.

Em um programa de melhoramento de plantas, é fundamental a obtenção de informações sobre o potencial genético dos genótipos em teste, quanto à capacidade per se e nos diferentes cruzamentos. Tais informações podem ser obtidas através dos cruzamentos dialélicos.

Os cruzamentos dialélicos são definidos, por diversos autores, como sendo todos os possiveis cruzamentos dentro de um determinado grupo de genótipos. Assim, com $n$ genótipos é possivel obter-se até $n^{2}$ combinações, ou seja, $n(n-1)$ cruzamentos mais os $n$ genótipos parentais. Na prática, os cruzamentos dialélicos permitem detectar tanto parentais como cruzamentos superiores, além de possibilitar ao melhorista eleger o método de melhoramento mais eficiente e possibilitar a estimação dos diversos parâmetros genéticos.

No método de Jinks \& Hayman (1953) ou de Hayman $(1956 a, b)$ pode-se utilizar $F_{1}, F_{2}$ e retrocruzamentos, tanto na tabela dialélica completa, com $n^{2}$ combinações, quanto com a exclusão dos reciprocos, com n(n-1)/2 combinações. Neste método, os dados da tabela dialélica podem ser utilizados para se fazer uma análise de variância, que fornece informações sobre a presença dos efeitos aditivos e dominantes (Sousa, 1998). O método permite estimar componentes de variância genética e parâmetros genéticos de importância prática, como por exemplo, as herdabilidades, tanto no sentido amplo quanto restrito e o grau médio de dominância 
(Mather \& Jinks, 1971). Também podem ser estimados outros parâmetros, como a proporção de alelos, com efeitos positivos e negativos nos parentais, razão entre o número total de genes de dominantes e recessivos nos parentais.

No método de Hayman, através da tabela dialélica, pode ainda ser realizada uma análise gráfica e da regressão do parâmetro estimado $W_{r}$ (covariância) em função de $\mathrm{Vr}$ (variância), o que é muito útil, pois fornece três informações básicas: a) um teste de eficiência do modelo, pois na ausência de epistasia e com distribuição independente dos genes entre os parentais, o coeficiente de regressão linear ( $\beta$ ) deve ser igual a um; b) uma medida do grau médio de dominância, através do ponto em que a linha de regressão corta a ordenada $W_{r}$. Em caso de sobredominância, a reta interseccionará 0 eixo $\left(W_{r}\right)$ abaixo da origem, em caso de dominância parcial, acima da origem, sendo que na ausência de dominância, a reta será tangente á parábola limitante; c) distribuição de genes dominantes e recessivos entre os parentais (Miranda, 1987). Na extremidade superior da reta ficam situados os parentais recessivos, próximos à parábola limitante. Já os parentais dominantes situam-se na extremidade inferior da reta, próximos da parábola limitante.

Esse método de análise dialélica permite um melhor conhecimento das relações genéticas entre os parentais envolvidos nos cruzamentos e também pode ser útil na identificação de cruzamentos superiores. No entanto, algumas restrições são impostas à aplicação do modelo: os parentais devem ser homozigotos; segregação diplóide; os genes devem ser distribuídos independentemente nos parentais; ausência de efeito materno, epistasia e alelismo múltiplo. No caso da soja, a segregação diplóide é uma característica normal da espécie e os demais requisitos podem ser, de certa forma, atendidos. Já a ausência de alelos múltiplos e epistasia podem apresentar alguns desvios; no entanto, o próprio modelo testa a significância desses desvios, só podendo ser aplicado quando não houver significância nos mesmos.

Uma outra alternativa de abordagem, consiste no método desenvolvido por Griffing (1956b), pela qual, as estimativas da CGC e CEC, obtidas pelos cruzamentos dialélicos, são rotineiramente usadas para realizar predições em espécies alógamas. Atualmente, vêm sendo utilizadas também em autógamas, embora não com a mesma intensidade; no entanto o número de trabalhos envolvendo análise dialélica em soja tem aumentado nos últimos anos. A metodologia de análise dialélica mais utilizada é a apresentada por Griffing (1956b), mais 
precisamente o método 2, modelo 1 e método 4 , modelo 1 . No método 2 são usados os parentais e os $F_{1}$ 's ou $F_{2}$ 's sem reciproco e no método 4 é usado apenas o conjunto de $F_{1}$ ou $F_{2}$ sem parentais e sem reciprocos. No modelo 1 todos os efeitos são fixos, com exceção do erro.

Vários estudos têm sido feitos para avaliar a capacidade de combinação de soja para diferentes caracteres. Um estudo de um dialelo em soja para seis características foi realizado por Singh et al. (1974), revelando que produtividade e número de vagens por planta foram controlados por ação gênica aditiva e não-aditiva (CGC e CEC); já para peso de 100 grãos e altura de planta, a variância genética aditiva foi altamente significativa, embora a variância nãoaditiva tenha também desempenhado um papel importante. Bhatade et al. (1977) avaliaram um dialelo completo em soja (excluindo reciprocos) envolvendo seis parentais e seus $15 F_{2}$ 's para cinco caracteres. As variâncias genéticas aditivas e não-aditivas foram importantes para os caracteres altura de planta e número de vagens por planta. Já para produtividade a variância genética aditiva foi a mais importante, com uma razão de 3,85 entre CGC/CEC.

Freire Filho (1988) avaliou a geração $F_{2}$ de um cruzamento dialélico envolvendo 10 genótipos precoces de soja e verificou que os efeitos aditivos foram mais importantes que os de dominância. Nass (1989) avaliou dialelo de soja também em $F_{2}$,objetivando cultivo de inverno. Dentre as diversas conclusões pode-se citar que os efeitos da capacidade geral de combinação foram significativos, denotando a importância dos efeitos aditivos. Outros trabalhos envolvendo dialelos em gerações iniciais também obtiveram resultados semelhantes aos citados anteriormente (Paludzyszyn Filho, 1982; Cruz et al., 1987; Pimentel, 1991; Krieger, 1992; Spehar, 1995).

Loiselle et al. (1990) propuseram um estudo para obter informações da natureza e do potencial genético através de um dialelo envolvendo 11 genótipos precoces de soja $\left(F_{1}\right.$ e $\left.F_{2}\right)$ em três ambientes. Neste estudo, a variação explicada pela CEC, embora significativa, foi sempre menor que a CGC. Consequentemente, justifica-se aplicar métodos de melhoramento que utilizam efeitos aditivos, como no caso estudado. No entanto houve inconsistência da CGC entre os locais para os caracteres produtividade, teores de óleo e proteína, sugerindo que a interação $G \times E$ foi importante e que deve ser estudada com mais cuidado.

Um outro trabalho realizado por Sharma et al. (1993) objetivou verificar o efeito de sistemas de plantio (solteiro e consórcio) e a magnitude de ação gênica para os caracteres dias 
para o florescimento e para a maturidade, altura da planta, produtividade e seus componentes. Para tanto, foram utilizados dez genótipos parentais e a geração $F_{2}$ de um dialelo em soja, cultivados ambos em sistema solteiro e consorciado. Pelos resultados constatou-se que 0 sistema de cultivo teve grande influência no controle genético da produtividade e seus componentes. Tanto a variância genética aditiva quanto a não-aditiva foram importantes na determinação genética de todos os caracteres. Contudo, a razão CGC/CEC foi maior no sistema solteiro que consorciado, de modo que a ocorrência de baixa correlação genótipica para produtividade e seus componentes em diferentes sistemas de cultivo justifica a seleção de diferentes parentais e cruzamentos para regimes solteiros e consorciados.

Spehar \& Galwey (1996) buscaram investigar diferenças genéticas na tolerância ao alumínio em soja a partir de um dialelo $(9 \times 9)$ envolvendo variedades contrastantes cultivadas em áreas com alumínio e em hidroponia. A CGC foi superior a CEC para todos os elementos (potássio, cálcio, ferro, alumínio, entre outros). Contudo a CEC também foi significativa $(p<0,05)$ em alguns casos, confirmando a presença de genes dominantes nos parentais. A razão CGC/CEC foi alta para cálcio e magnésio e baixa para alumínio e ferro. Em outro trabalho, Spehar (1999) identificou o modo de herança da produtividade de grãos e a taxa de absorção de nutrientes em soja, com cruzamentos dialélicos entre nove cultivares, sob baixa e elevada disponibilidade de alumínio. Dentre os resultados encontrados para os dois caracteres citados, pode-se citar que a CGC, que é função principalmente dos efeitos aditivos dos genes, foi superior em magnitude a CEC, embora está última também tenha apresentado significância $(p<0,05$ e $p<0,01)$. Já a razão CGC/CEC foi superior em ambientes com reduzido teor de alumínio e inferior no ambiente com altos teores de aluminio.

Pulcinelli (1997) verificou correlações altas entre as estimativas dos efeitos CGC obtidas em avaliações de populações de soja nas gerações $F_{2}$ e $F_{2: n}$. De acordo com o autor, a seleção dos parentais baseadas na CGC em $F_{2}$ pode ser um indicador seguro do potencial das populações endogâmicas. Gadag et al. (1999) analisaram a capacidade de combinação para produtividade, conteúdo de óleo e proteina, em um dialelo com sete parentais. Estimativas da CEC foram superiores às da CGC para todas as características mensuradas. A razão CGC/CEC indicou que para o conteúdo de proteina, produtividade e dias para maturidade os efeitos nãoaditivos foram predominantes. As médias dos parentais refletiram sua capacidade de 
combinação. Os cruzamentos superiores para o caráter produtividade envolveram parentais com alta $x$ baixa e baixa $x$ baixa CGC.

Cho \& Scott (2000) determinaram o tipo de ação gênica e a capacidade de combinação para o vigor da semente de soja e produtividade. Um dialelo parcial $(5 \times 6)$, envolvendo parentais com alto e baixo vigor da semente foram cruzados, tanto os parentais como as progênies $F_{2}$ 's foram avaliadas para vigor, produtividade e peso da semente. As estimativas da CGC para vigor e produtividade foram significativas $(p<0,01)$ e superiores às da CEC. Efeitos significativos para CGC e CEC foram encontrados para peso da semente, indicando que ambos os efeitos genéticos (aditivo e não-aditivo) estão envolvidos no controle do referido caráter. A razão $2 C G C /(2 C G C+C E C)$ foi 0,96 para vigor e 0,93 para produtividade. Estas razões indicam que 0 efeito aditivo foi mais importante que 0 não-aditivo para vigor e produtividade nestes cruzamentos. De forma geral, estes resultados indicam que os diferentes niveis de vigor da semente podem ser melhorados, ao mesmo tempo em que se mantém altas produtividades, isso por causa da predominância da CGC presente nos caracteres vigor da semente e produtividade.

A grande maioria dos trabalhos citados foram conduzidos em apenas um ambiente. $\mathrm{Na}$ tentativa de obter informações mais consistentes, alguns autores têm desenvolvidos metodologias de estudos dialélicos repetidos em vários ambientes (locais, anos). A análise conjunta desses ensaios inclui, além das fontes de variação encontradas nas análises individuais, as interações dos efeitos principais com os ambientes.

Singh (1973a,b, 1979) apresenta os procedimentos estatisticos para realizar ensaios dialélicos em vários ambientes, detalhando os métodos I, II, III e IV propostos por Griffing. Oliveira et al. (1987) apresentam a metodologia da análise de variância conjunta de cruzamentos dialélicos parciais, a partir do modelo proposto por Miranda Filho \& Geraldi (1984) adaptado de Gardner \& Eberhart (1966). Já Morais et al. (1991) apresentaram um método para análise conjunta da variância de cruzamentos dialélicos de variedades, a partir do modelo proposto por Gardner \& Eberhart (1966), quando estes são repetidos em vários ambientes, com vistas à obtenção de estimadores dos parâmetros e das somas de quadrados. Ferreira et al. (1993) adaptaram a metodologia de análise de cruzamentos dialélicos propostos por Griffing, onde são avaliados somente os hibridos (método IV) para vários ambientes. 


\subsection{Caracteres agronômicos em soja}

O desenvolvimento e aplicação de modelos genético-estatísticos e a decomposição de parâmetros tais como médias, variâncias e covariâncias a partir de uma tabela dialélica têm sido a principal estratégia para o conhecimento do tipo de ação gênica que controla a expressão fenotipica dos principais caracteres quantitativos de importância agronômica e comercial em espécies autógamas (Soldini, 1998). De acordo com Toledo \& Kiihl (1982a), a dificuldade de compreensão e adaptação das metodologias disponiveis para o estudo dos mecanismos de ação gênica tem causado alguns problemas aos melhoristas de plantas, notadamente autógamas. Estes problemas se traduzem por dificuldades na tomada de decisão quanto aos processos ou métodos mais adequados na condução e ou seleção de seus materiais.

0 controle genético do tempo para o florescimento e a maturidade em soja, sob condições de dias curtos, é diferente daquele verificado em condições de dias longos. Ocorre uma alteração nestes periodos com a mudança nas condições de cultivo de regiões com dias curtos para aqueles com dias longos, comuns em regiões com maior latitude. Toledo \& Kiihl (1982a) realizaram análises com a finalidade de obter informações sobre o modelo genético em controle da característica dias para florescimento. Os autores concluiram que pelo menos três genes controlam o caráter, através de efeitos aditivos e dominantes. Em um outro trabalho Toledo \& Kiihl (1982b), utilizando as metodologias de Griffing (1956b) e Hayman (1954b), estudaram o mecanismo de herança das características dias para floração e número de folhas trifolioladas em condições de dias curtos. As análises indicaram que no material estudado apenas um gene está envolvido no controle de cada característica.

Posteriormente, Toledo et al. (1993) estudaram os mecanismos genéticos que controlam a resposta fotoperiodica de seis cruzamentos em três fotoperiodos. Dentre as características estudadas, destacaram-se altura da planta e dias para o florescimento. Os resultados mostraram que efeitos gênicos aditivos predominam no controle de todas as características e que a seleção para adaptação para dias para florescimento e altura da planta deve ser feita em cada época de semeadura. Há provavelmente um mecanismo genético simples, envolvendo vários locos, controlando dias para o florescimento em soja nos três fotoperiodos. Dando sequiência a este trabalho, Toledo et al. (1994) estudaram a resposta do 
florescimento à variação do fotoperiodo e os mecanismos genéticos que controlam esta resposta. Eles concluiram que houve uma predominância dos efeitos aditivos no controle do caráter dias para florescimento; no entanto, os efeitos de dominância, epistasia e interação genótipo $x$ ambiente também foram significativos.

Bonato \& Vello (1999) estudaram os mecanismos genéticos do tempo para 0 florescimento através do método proposto por Hayman (1954b); os autores constataram que 0 principal componente de variação genética para o caráter dias para o florescimento foi 0 aditivo. Os resultados evidenciaram ainda que o retardamento do inicio do florescimento é determinado por alelos recessivos e os alelos que condicionaram a precocidade exibiram dominância parcial; identificaram o gene $E_{6}$ como controlador do florescimento precoce em condições de dias curtos.

A característica período juvenil longo (PJL) em soja tem sido definida como 0 retardamento do florescimento sob condições de dias curtos. Ray et al. (1995) estudaram 0 controle genético do PJL. Foram realizados três experimentos. No primeiro, o padrão de segregação do PJL foi examinado em seis populações $F_{2}$ originadas dos cruzamentos entre linhagens com periodo juvenil convencional (PJC) e a PI 159925 (fonte de PJL). Os resultados indicaram que o PJL é controlado por um único gene recessivo influenciado pelo blackground genético em que ele ocorre. No segundo experimento, um total de 1952 plantas $F_{2}$ 's foram observadas em oito cruzamentos; dentro de todas as populações foi encontrada uma segregação 3:1 (PJC:PJL). No último experimento foi estudado a relação de dominância dos alelos através das gerações $F_{5}$ e $F_{6}$; os resultados indicaram que 0 alelo J, que condiciona o fenótipo PJC, é provavelmente de dominância completa. Os resultados indicam que o PLJ é controlado por um gene recessivo e o simbolo $\mathrm{Jj}$ foi sugerido para os alelos que condicionam a resposta ao florescimento.

Destro et al., (2001), após uma detalhada revisão sobre fotoperiodismo e controle genético do periodo juvenil longo (PJL) em soja, chegou às seguintes conclusões: a) plantas com PJl apresentam uma menor taxa de desenvolvimento em direção ao florescimento, resultando no alongamento do periodo vegetativo; b) a característica PJI tem uma influência direta sobre a fotorrecepção da planta e sobre a indução floral; c) 0 controle genético do tempo para 0 florescimento em dias curtos é determinado por um sistema genético diferente e independente daquele que determina o florescimento em dias longos; d) o florescimento tardio sob condições 
de dias curtos é uma característica quantitativa controlada por genes recessivos, sendo considerado a presença de um a cinco genes principais controlando o florescimento. Genótipos com um único par de alelos recessivos não manifestam PJL.

Yamanaka et al. (2000) analisaram QTLs relacionados ao número de dias para florescimento e construíram um mapa de ligação usando uma população $F_{2}$ derivada do cruzamento entre Misuzudaizu e Moshidou Gong 503. Foram identificados três QTLs (FT1, FT2 e FT3) para dias para florescimento. Os alelos FT1 e FT3 presentes no Moshidou Gong 503 e 0 FT2 no Misuzudaizu reduziram o caráter em estudo. O QTL mais efetivo (FT1), explicou $70 \%$ da variação total e parece corresponder ao E1 do mapa genético clássico.

Um outro caráter bastante importante é o teor de óleo em grãos de soja. Essa característica é difícil de se estudar por ser poligênica, complexa e responsiva aos efeitos ambientais presentes durante 0 desenvolvimento da planta. 0 controle genético é principalmente aditivo (Brim \& Cockerham, 1961); no entanto, algumas evidências de efeitos epistáticos também têm sido encontradas (Hanson \& Weber, 1961, 1962). Miranda et al. (1998) estudaram o teor de óleo em soja sob diferentes fotoperíodos e temperaturas. Para tanto foram utilizados quatro genótipos como parentais e as gerações descendentes $F_{2}, F_{3}$ e $F_{9}$ semeadas nos meses de setembro, outubro e dezembro. A variância genética aditiva foi significativa para todos os cruzamentos e épocas de semeadura. Os efeitos aditivos foram maiores em setembro e outubro e a interação do tipo aditivo $x$ aditivo foi importante em outubro. Efeitos de dominância significativos foram mais freqüentes em dezembro e outubro, geralmente no sentido de aumentar o teor de óleo nas sementes e as herdabilidades variaram de $15 \%$ a $43 \%$, com maiores valores para semeadura de setembro.

Raut et al. (2000) realizaram uma análise genética, pelo método proposto por Hayman (1958), em sete caracteres quantitativos em três cruzamentos de soja, envolvendo as gerações $F_{1}, F_{2}$ e $F_{3}$. Efeitos gênicos aditivos foram significativos para altura da planta, teor de óleo e peso de cem sementes. Efeitos de dominância foram significativos para altura de planta, número de vagens por planta, sementes por planta, produtividade e teor de óleo. A presença da epistasia do tipo dominante $\mathrm{x}$ dominante $\mathrm{e}$ aditivo $\mathrm{x}$ aditivo ocorreu em todos os cruzamentos.

A produtividade de grãos em soja é um caráter essencialmente quantitativo, sendo que a variância genética aditiva e a variância devido à epistasia do tipo aditivo $x$ aditivo têm sido os 
principais componentes (Brim \& Cockerham, 1961). No entanto, alguns trabalhos apresentaram variância de dominância superiores às aditivas (Tawar et al., 1989; Li et al., 1991; Pacova 1992; Raut et al., 2000).

Ao longo do desenvolvimento do melhoramento genético da soja, a produtividade de grãos per se tem sido um dos mais importantes objetivos da seleção cíclica, na qual cultivares superiores liberados são recombinados e suas progênies superiores novamente liberadas para cultivo comercial. A história deste processo recorrente de modificações genéticas quantitativas, associadas a uma melhoria nas condições ambientais de cultivo, tem proporcionado ganhos genéticos significativos (Soldini, 1998).

Sabe-se que os avanços genéticos obtidos e os atuais potenciais de produtividade são resultados da acumulação progressiva de poligenes, além da avaliação de caracteres morfológicos e fisiológicos essenciais à adaptabilidade agronômica e ambiental dos genótipos. Todos estes fatores são decisivos para que o potencial genético da produtividade de grãos per se seja expresso nos fenótipos. Outros caracteres também são importantes, tais como, número de dias para o florescimento e altura da planta no florescimento e na maturidade, responsáveis pela capacidade de crescimento vegetativo e adaptação ao fotoperíodo. 


\section{CORRELAÇÕES GENOTÍPICAS, FENOTÍPICAS E DE AMBIENTE EM CRUZAMENTOS DIALÉLICOS DE SOJA}

\section{RESUMO}

Avaliaram-se 21 genótipos de soja [(Glycine max (L.) Merrill)], sendo seis parentais e suas 15 combinações dialélicas em $F_{2}$, em dois locais (ESALQ e Anhembi) do município de Piracicaba - SP. As características avaliadas foram NDF- Número de dias para o florescimento; APF-Altura da planta no florescimento; NDM- Número de dias para a maturidade; APM- Altura da planta na maturidade; VA- Valor agronômico; PG- Produtividade de grãos; \%OL - Teor de óleo na semente; PO - Produtividade de óleo por planta. Parentais e $F_{2}$ apresentaram variabilidade para todos os caracteres. Em termos de qualidade ambiental favorável, os dois locais foram bons para a expressão do potencial genético dos genótipos avaliados, no entanto o local Anhembi foi mais favorável para PG. A interação genótipos $x$ locais foi um importante componente da variação fenotípica, com exceção do caráter \%OL. As correlações genotípicas foram geralmente maiores que as fenotípicas e de ambiente nos dois locais. A magnitude apresentada pelas correlações fenotípica e genotipica, mostra que o fenótipo refletiu satisfatoriamente o genótipo. Os caracteres relacionados ao florescimento à maturidade mostraram-se importantes para o melhoramento da

produtividade. Existe evidência de dificuldades em obter novos genótipos produtivos e precoces. 


\section{GENOTYPIC, PHENOTYPIC AND ENVIRONMENTAL CORRELATIONS IN SOYBEAN DIALLEL CROSSES}

\section{SUMMARY}

Twenty-one soybean genotypes [(Glycine $\max (L$.$) Merrill)] were evaluated, being six$ parents and their 15 diallel crosses in $F_{2}$, in two localities (ESALQ and Anhembi) of Piracicaba, State of São Paulo, Brazil. The characteristics evaluated were NDF - number of days to flowering; APF - plant height at flowering; NDM - number of days to maturity; APM - plant height at maturity; $V A$ - agronomic value; $P G$ - seed yield; $\% O L$ - seed oil content; $P O$ - oil yield. Parents and $F_{2}$ presented variability for all the characters. In terms of favorable environmental quality, the two localities were good for the expression of the genetic potential of the genotypes evaluated, however Anhembi was the most favorable for the expression of the seed yield. The $G \times L$ interaction was an important component of the phenotypic variation, except for the character $\% \mathrm{OL}$. The genotypic correlations were usually larger than the phenotypic and of environmental in the two localities. The magnitude presented by the phenotypic and genotypic correlations, it shows that the phenotype reflected the genotypes satisfactorily. The characters related to the flowering and maturity were shown important for the improvement of the seed yield. There is an evidence of difficult to develop new soybean genotypes with high seed yield and earliness. 


\subsection{INTRODUÇÃO}

A soja (Glycine max (L.) Merrill) é umas das mais importantes oleaginosas cultivadas no mundo, principalmente devido aos elevados teores de proteína (40\%), óleo (20\%) e pelo alto rendimento de grãos. No Brasil, ela é cultivada numa grande diversidade de ambientes, englobando altas e baixas latitudes. Devido a essa ampla variação, torna-se fundamental a seleção de genótipos com elevada produtividade e adaptabilidade a vários ambientes.

A maioria dos programas de melhoramento envolvem quatro etapas principais: a) escolha dos parentais; b) cruzamentos entre parentais e obtenção de genótipos segregantes; c) avanço das gerações iniciais através de autofecundações naturais; d) teste de desempenho agronômico e seleção das linhagens experimentais. A etapa intermediária correspondente ao avanço das gerações de endogamia tem sido feita de forma relativamente rotineira, com a finalidade principal de desenvolver genótipos homozigóticos, os quais estando livres das combinações alélicas heterozigóticas e tendo fixado as combinações epistáticas favoráveis, aumentam a eficiência dos testes de desempenho agronômico. Além disso, as linhagens homozigóticas podem ser avaliadas com precisão experimental superior, pois dispõem de um maior número de sementes para locais, épocas de cultivo e anos agrícolas. Por outro lado, o avanço das gerações de endogamia tem como desvantagens o aumento do número de anos de cada ciclo do programa de melhoramento e a demanda adicional de recursos humanos e financeiros. Essas limitações poderiam ser contornadas pela eficiente e eficaz escolha dos parentais e pela avaliação e seleção dos genótipos promissores logo nas gerações iniciais, de maneira que somente estes genótipos selecionados sejam avançados até originarem linhagens superiores. Essa estratégia consegue eliminar ou reduzir, já nas gerações iniciais, problemas de incompatibilidade hibrida e diferenças na capacidade de combinação que levem à ocorrência de cruzamentos inferiores.

Existem poucas informações sobre o comportamento da soja logo nas gerações iniciais. Isso ocorre pela dificuldade de realização dos cruzamentos, limitada quantidade de sementes colhidas nas plantas $F_{1}$ e que muitas vezes inviabiliza o estudo nas gerações iniciais, além do trabalho despendido com as avaliações. 
Os testes das gerações iniciais $\left(F_{1}, F_{2}, F_{3}\right)$ podem ser feitos em ambientes diversos (locais, épocas de cultivo, anos agricolas), possibilitando a estimação da interação genótipos $x$ ambientes e a quantificação de seus efeitos sobre a expressão fenotipica dos caracteres e sobre as estimativas de parâmetros genéticos importantes na seleção dos melhores genótipos, tais como, variância genética, herdabilidade, ganho esperado na seleção e correlação entre caracteres (Rocha \& Vello, 1999).

A correlação reflete o grau de associação entre caracteres. Seu conhecimento é importante porque mostra como a seleção para um caráter influencia a expressão de outros caracteres. Nos programas de melhoramento, geralmente, além de se visar 0 aprimoramento de um caráter principal, busca-se também manter ou melhorar a expressão de outros caracteres simultaneamente.

Em soja, os estudos sobre correlações genotipicas, fenotipicas e de ambiente tem envolvido os caracteres coletados desde 0 florescimento até a maturação, destacando-se a produtividade e seus componentes e, mais recentemente, envolvendo análises quantitativas e qualitativas de óleo e proteína. (Paschal \& Wilcox, 1975; Sharma, 1979; Freire Filho, 1988; Cecon et al., 1993; Akhter \& Sneller, 1996a,b; Peluzio, 1996; Taware et al., 1997; Morrison et al., 2000).

Este trabalho teve os seguintes objetivos: avaliar a variabilidade existente em parentais e cruzamentos $F_{2}$; estimar a interação genótipos x loøais; e, өstimar as correlações genotipicas, fenotipicas e ambientais entre caracteres.

\subsection{MATERIAL E MÉTODOS}

\subsubsection{Material genético}

Seis genótipos de soja foram escolhidos pela produtividade de grãos, tolerância ao fotoperiodo e resistência a doenças, para uso como parentais (Tabela 3.1): (1) Hartwig: cultivar exótico, liberado nos Estados Unidos como sendo resistente a todas as raças de nematóide do cisto da soja, NCS, Heterodera glycines, Ichinohe (Anand, 1992); (2) USP 1-11: linhagem pura selecionada dentro da linhagem experimental USP 1, com resistência às raças 1 e ou 3 de NCS, ao cancro-da-haste da soja (CHS, Diaporthe phaseolorum f. sp. Meridionalis Morgan-Jones) e à mancha olho-de-rã (Cercospora sojina Hara), com hábito de crescimento indeterminado; (3) 
Conquista: cultivar comercial, adaptado às condições ambientais do Brasil Central, com tolerância ao fotoperíodo e resistências às doenças $\mathrm{CHS}$, mancha olho-de-rã e tolerante ao nematóide de galha (Faria et al., 1998); (4) USP 2-16: linhagem pura selecionada dentro da linhagem experimental USP 2, com resistência às mesmas três doenças relacionadas em USP 1 11 e hábito de crescimento determinado; (5) MT BR 123.800: linhagem experimental desenvolvida pelo Convênio EMBRAPA-CNPSo e Fundação Mato Grosso, com tolerância ao fotoperíodo e resistência às doenças NCS e moderadamente resistente ao CHS (Takeda'1); (6) USP 5-19: linhagem pura selecionada dentro da linhagem experimental USP 5, com resistência às raças 1 e ou 3 de NCS; hábito de crescimento determinado.

As linhagens puras USP 1-11, USP 2-16 e USP 5-19 foram desenvolvidas pelo Setor de Genética Aplicada às Espécies Autógamas, do Departamento de Genética ESALQ/USP (Vello et al., 1994; Hiromoto, 1996; Miranda, 1999).

\subsubsection{Caracterização do ambiente}

Os ambientes de condução dos experimentos localizam-se no município de

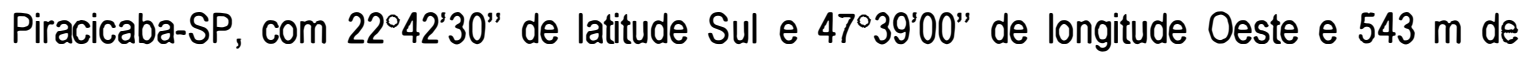
altitude. Compreende dois locais administrados pelo Departamento de Genética da ESALQ/USP:

a) ESALQ: área experimental localizada na própria sede, com solo do tipo terra roxa estruturada, textura argilosa, relevo ondulado e alta fertilidade;

b) Estação Experimental Anhembi: caracterizado por solo aluvial distrófico, textura médio-arenosa, relevo plano, situado à $60 \mathrm{~km}$ da sete ESALQ; a acidez e a toxidez de alumínio neste solo foram neutralizadas pela aplicação de calcário dolomítico em anos anteriores.

1 TAKEDA, C (Fundação MT, Rondonopólis). Comunicação pessoal, 1997). 


\subsubsection{Procedimentos experimentais}

\subsubsection{Obtenção de sementes $F_{1}$}

No ano agrícola $1997 / 98$ foram realizados os cruzamentos planta-a-planta em telado, utilizando a técnica de múltiplas datas (8-10) de semeadura, visando-se sincronizar o florescimento e incrementar o período de floração. Parentais com marcadores fenotípicos recessivos (flor branca e pubescência cinza) foram empregados de preferência como fêmeas para facilitar e antecipar a confirmação dos hibridos $F_{1}$.

A semeadura dos parentais para os cruzamentos foi realizada em vasos de cerâmica com uma mistura de três partes de terra e uma parte de adubo orgânico e após a germinação foi feito um desbaste, deixando-se duas plantas por vaso.

Os cruzamentos foram realizados pela manhã e tarde. Utilizou-se a técnica da emasculação parcial, ou seja, no parental feminino, usaram-se botões florais que deveriam abrir no dia seguinte, extraindo-se as pétalas com uma pinça de modo a expor o estigma e parte dos estames. No parental masculino colheram-se flores abertas no dia, das quais se extraiu a coluna estaminal mais o estigma impregnado de pólen, o qual foi em seguida levemente friccionado sobre o estigma da flor do parental feminino, resultando na polinização controlada. Após essa etapa, fez-se a identificação do cruzamento com uma etiqueta que continha a origem do cruzamento, o número de flores polinizadas na inflorescência e as iniciais da pessoa que 0 efetuou. As vagens oriundas dos cruzamentos foram identificadas e colhidas individualmente na maturidade.

\subsubsection{Obtenção de sementes $F_{2}$}

No inverno de 1998 foi realizado o avanço da geração $F_{1}$ em casa-de-vegetação com controle das condições de luminosidade, temperatura e umidade, assegurando-se boa quantidade de sementes $F_{2}$ por cruzamento. $A$ decisão de adiantar uma geração em condições controladas foi tomada devido às baixas temperaturas apresentadas no inverno de 1998 e pelo reduzido número de sementes $F_{1}$ por cruzamento. As sementes foram germinadas em condições 
de laboratório e após quatro dias, as plântulas foram transferidas diretamente para os vasos de cerâmica. Foi feito o controle dos marcadores fenotipicos (cores de hipocótilo, flor e pubescência) para confirmar os cruzamentos envolvendo parentais empregados como fêmea e macho, com marcadores recessivos e dominantes, respectivamente, sendo os restantes dos cruzamentos confirmados em plantas $F_{2}$. As plantas $F_{1}$ foram colhidas individualmente e com as sementes $F_{2}$ foi preparado o experimento para coleta dos dados experimentais.

\subsubsection{Delineamento e características do experimento}

Os 21 tratamentos (seis parentais e 15 cruzamentos $F_{2}$ ) foram avaliados no delineamento experimental de blocos ao acaso, com seis repetições por local (ESALQ e Anhembi).

A parcela foi representada por 12 covas de plantas individuais espaçadas de $0,80 \mathrm{~m} \times$ $0,80 \mathrm{~m}$, totalizando uma área útil de $7,68 \mathrm{~m}^{2} ;$ no total, foram pesquisadas 144 plantas $F_{2}$ de cada cruzamento. A semeadura foi realizada no mês de novembro, sendo semeadas 12 sementes por cova e após 15 dias foi realizado o desbaste para uma planta por cova (método SHDT: Single Hill Descent Thinned, Vello, 1992).

\subsubsection{Caracteres avaliados}

Os dados coletados em plantas individuais referem-se aos seguintes caracteres:

NDF- Número de dias para o florescimento, contados a partir da data de semeadura até o início do florescimento (Estágio $R_{1}$ da escala de Fehr \& Caviness, 1977);

APF- Altura da planta, em $\mathrm{cm}$, no início do florescimento, medido desde a base até 0 ápice da haste principal;

NDM- Número de dias para a maturidade, contados a partir da data de semeadura até a data em que a planta apresentou $95 \%$ das vagens maduras (Estágio $\mathrm{R}_{8}$ da escala de Fehr \& Caviness, 1977);

APM- Altura da planta, em $\mathrm{cm}$, na maturidade, medido desde a base até 0 ápice da haste principal; 
VA- Valor agronômico, avaliado na maturidade. Nesse caráter foi usado uma escala de notas visuais variando de 1 a 5 , onde 1 correspondeu a uma planta sem nenhum valor agronômico e 5 a uma planta com excelentes características agronômicas (grande número de vagens, sem acamamento, ausência de haste verde e de folhas verdes, sem debulha, sem sintomas de doenças);

PG- Produtividade de grãos por planta ( $g /$ planta), avaliada na maturidade;

\%OL- Teor de óleo nas sementes da geração $F_{3: 2}$ (devido à herança materna, as sementes $F_{3}$ refletem o genótipo da planta mãe $F_{2}$ ). A avaliação é feita em uma amostra de cerca de 2,5 a 3,0 g, através da metodologia não-destrutiva de espectrometria de ressonância nuclear magnética (NMR), utilizando-se 0 espectrômetro desenvolvido pela EMBRAPA-CNPDIA, São Carlos - SP;

PO- Produtividade de óleo por planta, obtida pelo produto entre a produtividade de grãos (PG) e o teor de óleo nas sementes (\%OL), dividido por 100.

\subsubsection{Caracteres auxiliares}

Foram também coletados dados de alguns caracteres a titulo de conhecer melhor os genótipos avaliados e de separar cruzamentos de autofecundações indesejáveis, nos casos que não foi possivel fazer esta identificação em $F_{1}$.

CF. Cor das flores;

CV-Cor das vagens;

CP- Cor da pubescência;

AC- Acamamento, avaliado na maturidade. Para este caráter foi usado uma escala variando de 1 a 5 , onde a nota 1 correspondeu a uma planta ereta e 5 a uma planta completamente acamada. 


\subsubsection{Análises estatístico-genéticas}

As análises estatísticas dos dados foram realizadas utilizando-se os programas computacionais SAS (SAS INSTITUTE INC, 1997) e GENES (Cruz, 1997).

As análises dos caracteres foram realizadas com base na média das observações feitas em plantas individuais de cada parcela. Para o caráter valor agronômico, as análises foram realizadas com dados transformados para $\sqrt{x+0,5}$.

\subsubsection{Análises individual e conjunta}

Foram realizadas análises de variância individuais e conjuntas considerando-se como fixos os efeitos de tratamentos (parentais e cruzamentos $F_{2}$ ), visto que os parentais foram escolhidos para atender um objetivo especifico. O efeito de locais foi considerado fixo, uma vez os mesmos foram escolhidos por seres contrastantes em uma série de características ( topografia, propriedades químicas e físicas do solo). $O$ efeito de interação genótipos $x$ locais também foi considerado fixo; já o efeito de repetições considerado aleatório. Os esquemas das análises de variância constam nas Tabelas 3.2 e 3.3.

Em razão de se considerar como fixos os efeitos de tratamentos (parentais e cruzamentos $F_{2}$ ), que as inferências possiveis de serem realizadas devem se limitar ao material em estudo.

Os modelos matemáticos utilizados para a análise de variância individual e conjunta foram respectivamente:

$Y_{i j}=\mu+t_{i}+r_{j}+e_{i j}, \quad$ sendo:

$Y_{\text {ij: }}$ observação do tratamento "i", na repetição "j";

$\mu$ : média geral do caráter;

t: efeito fixo do tratamento $i ; i=1,2, \ldots, l$;

$r_{j}$ : efeito aleatório da repetição j; j=1, 2, ..., J;

$e_{i j}$ : erro experimental associado à parcela "ij”. 
$Y_{i j k}=\mu+t+r_{i k k}+l_{k}+(t)_{i k}+e_{i j k}$

$Y_{i j k}$ observação do tratamento "i", na repetição "j", no local "k";

$\mu$ : média geral do caráter;

t: efeito fixo do tratamento $i ; i=1,2, \ldots$, i;

ri: efeito aleatório da repetição j, dentro do local " $k$ "; j=1, 2, ..., J;

$l_{k}$ : efeito fixo do local " $k$ "; $k=1,2, \ldots ., k$;

$(t)_{i k}$ : efeito fixo da interação entre o tratamento ï' e o local " $k$ ";

$e_{i j k}$ : erro experimental associado à parcela "ijk"

\subsubsection{Análises de médias}

Foi utilizado o teste de Scott-Knott para comparações de médias entre os parentais e cruzamentos $F_{2}$ nos dois locais, ao nivel de $5 \%$ de probabilidade.

\subsubsection{Análises de correlações}

As correlações entre os oito caracteres foram estimadas por local para os parentais, que constituem um grupo de genótipos homozigóticos e para os 15 cruzamentos $F_{2}$ que constituem um grupo com uma média de somente $50 \%$ dos locos em homozigose. Para cada grupo foram estimadas as correlações fenotipicas ( $\left.\mathrm{r}_{\mathrm{F}}\right)$, genotipicas $\left(\mathrm{r}_{\mathrm{G}}\right)$ e de ambiente $\left(\mathrm{r}_{\mathrm{E}}\right)$.

No cálculo das correlações foi usada a seguinte relação apresentada por Kempthorne (1969):

$V(x+y)=V(x)+V(y)+2 \operatorname{Cov}(x y)$

de modo que:

$\operatorname{Cov}(x y)=\frac{V(x+y)-V(x)-V(y)}{2}$

onde se tem que:

$\mathrm{V}(\mathrm{x})=$ variância do caráter $\mathrm{x}$;

$V(y)=$ variância do caráter $y$; 


$$
\begin{aligned}
& V(x+y)=\text { variância da soma dos caracteres } x \text { e } y ; \\
& \operatorname{Cov}(x y)=\text { covariância entre os caracteres } x \text { e } y ;
\end{aligned}
$$

Para a obtenção desses parâmetros fez-se a análise de variância dos caracteres $x$ e y individualmente e da soma desses caracteres $(x+y)$. A partir dessas análises e utilizando a relação apresentada por Kempthorne (1969) foram estimadas as covariâncias ou produtos médios para os pares de caracteres ( $x, y)$ (Tabela 3.4). Usando a nomenclatura dessa Tabela tem-se:

$$
P M(x y)=\frac{Q M(x+y)-Q M x-Q M y}{2}
$$

A partir dos quadrados médios (variâncias) e dos produtos médios (covariâncias) foram estimadas as correlações através das seguintes expressões:

Correlação fenotipica $\left(\mathrm{r}_{\mathrm{F}}\right)$ :

$$
r_{F}=\frac{\mathrm{PMT}_{(x y)}}{\sqrt{\mathrm{QMT}_{\mathrm{x}} \cdot \mathrm{QMT}_{\mathrm{y}}}}
$$

Correlação genotipica $\left(r_{G}\right)$ :

$$
r_{G}=\frac{\phi_{t(x, y)}}{\sqrt{\phi_{t(x)}^{2} \cdot \phi_{t(y)}^{2}}}
$$

Correlação ambiental ( $\left.\mathrm{r}_{\mathrm{E}}\right)$ :

$$
r_{E}=\frac{P M E_{(x y)}}{P M E_{(x)} P M E_{(y)}}
$$

\subsection{RESULTADOS E DISCUSSÃO}

\subsubsection{Análises de variâncias individuais}

Nas análises individuais, parentais $(P)$ e cruzamentos $\left(F_{2}\right)$ apresentaram efeitos significativos para todos os caracteres nos dois locais (Tabelas 3.5 e 3.6), mostrando a existência de variabilidade nos dois tipos de materiais genéticos avaliados. A comparação da média dos parentais com a média dos cruzamentos $F_{2}$, feita através da fonte de variação ( $P$ vs $F_{2}$ ), 
geralmente foi significativa, as exceções foram observadas nos caracteres PG e \%OL no local ESALQ e APM, VA, \%OL em Anhembi, revelando diferenças entre as médias dos dois grupos de genótipos para a maioria dos caracteres, independentemente do ambiente. Já para 0 caráter $\% O L$, não houve diferenças entre as médias obtidas para parentais e para cruzamentos $F_{2}$, indicando que o comportamento do teor de óleo foi semelhante para os dois grupos de materiais genéticos. Resultados similares foram obtidos por Paschal \& Wilcox (1975) utilizando geração $F_{1}$ e por Soldini (1998) cujo caráter \%OL foi o que exibiu menor variabilidade em $\mathrm{F}_{2}$.

Com relação às médias pode-se observar que o local Anhembi foi mais favorável para os caracteres NDM e PG, apresentando plantas mais precoces e um pouco mais produtivas que aquelas cultivadas na ESALQ. Quanto aos coeficientes de variação (CVs), os valores foram baixos e semelhantes nos dois locais, denotando uma boa precisão experimental; os menores valores de CVs foram observados para NDM, NDF, \%OL e VA na ESALQ, e, para NDF, NDM, \%OL e VA em Anhembi; valores intermediários de CVs ocorreram para APF, APM, PO e PG nos dois locais, embora em Anhembi os caracteres PG e PO atingiram valores mais altos de CVs $(14,48$ e 15,92\%) do que na ESALQ; magnitudes maiores de CV para PG e PO confirmam a natureza complexa (muitos genes) dos mesmos, razão pela qual estes caracteres são muito influenciados pelo ambiente. Esses resultados indicam ainda que a precisão foi maior para NDF e NDM, e menor para PG e PO. Os valores encontrados são considerados bons para experimentos em covas, sendo próximos e até mesmo mais precisos que aqueles obtidos por Soldini (1998) em $\mathrm{F}_{2}$.

Os coeficientes de determinação $\left(R^{2}\right)$ mostraram condições experimentais normais e significativa proporção da variação dos dados explicada pelos modelos matemáticos. Os dados correspondentes a \%OL $\left(R^{2}=0,61\right)$ na ESALQ tiveram ajuste menor, provavelmente devido aos efeitos adicionais de leitura pelo aparelho de ressonância magnética nuclear (NMR). No caso de PG $\left(R^{2}=0,67\right)$ em Anhembi, 0 fato de ser um caráter quantitativo, bastante influenciado pelo ambiente e que também participa de PO $\left(R^{2}=0,64\right)$, explica ajustes menores para esses caracteres. Resultados semelhantes foram obtidos em gerações inicias (Soldini, 1998) e em gerações avançadas de endogamia (Laínez-Mejia, 1996; Rocha, 1998). 


\subsubsection{Análise de variância conjunta}

A análise de variância conjunta, com os quadrados médios, média geral, coeficientes de variação (CVs) e coeficientes de determinação $\left(R^{2}\right)$ referentes aos caracteres NDF, APF, NDM, APM, VA, PG, \%OL e PO são apresentadas na Tabela 3.7 .

Foram detectadas diferenças significativas para locais $(L)$, tratamentos $(T)$ e seu desdobramento em parentais $(P)$ e cruzamentos $\left(F_{2}\right)$ para a maioria dos caracteres. Isso indicando a presença de variabilidade entre os genótipos e os ambientes; já o contraste $P$ vs $F_{2}$ (G) apresentou significância para a maioria dos caracteres (exceto PG, \%OL e PO), mostrando existência de diferenças entre a média dos parentais e a média dos cruzamentos $F_{2}$, nos dois locais. A interação tratamentos $\times$ locais $(T \times L)$ mostrou significância $(p<0,05$ e $p<0,01)$ para todos os caracteres, revelando uma resposta diferenciada dos genótipos nos dois locais. A interação $T$ $x \mathrm{~L}$ significativa sugere a necessidade de se selecionar genótipos especificos para cada local e ou identificar aqueles que não apresentam variações através dos locais.

Desdobrando-se $T \times L$ em parentais $\times$ locais $(P \times L)$ e cruzamentos $F_{2} \times$ locais $\left(F_{2} \times L\right)$, verifica-se que apenas um caráter foi não-significativo (\%OL). A ausência de interação para \%OL também foi reportada por Soldini (1993), Lainez-Mejia (1996) e Rocha (1998). As significâncias das interações $P \times L$ e $F_{2} \times L$, para quase todos os caracteres, indica a existência de um comportamento diferencial dos parentais e dos cruzamentos $F_{2}$ nos dois locais. Segundo Scott \& Kephart (1997), uma vez identificados os melhores cruzamentos, vários locais de teste podem ser necessários para identificar os individuos superiores para características especificas. Interações significativas também foram obtidas por Hegstad et al. (1999) e Sood et al. (1999). Este resultado indica que a seleção de cruzamentos superiores deve considerar o local especifico para todos os caracteres, exceto a \%OL. Para este, a seleção pode ser praticada independentemente do local, pois os cruzamentos exibiram adaptação aos locais de teste, ou seja, um único ambiente de avaliação pode ser adequado para identificar os melhores cruzamentos.

A comparação da média dos parentais com a média dos cruzamentos $F_{2}$, pelo contraste $\left(P\right.$ vs $\left.F_{2}\right) \times L$, revela se a diferença entre as médias dos parentais e cruzamentos $F_{2} \dot{e}$ consistente de um local para outro; neste caso, a fonte locais $(L)$ influenciou as diferenças para a 
maioria dos caracteres, exceto para APM, VA e \%OL. Pode-se dizer que o caráter \%OL não apresentou diferenças entre $P$ e $F_{2}$ nos dois locais, ou seja, houve a manutenção do comportamento do caráter independentemente do ambiente.

Ainda de acordo com a Tabela 3.7, 0 efeito de locais $(L)$ foi significativo para a maioria dos caracteres, exceto APM, \%OL e PO. Isto indica que os locais são bem variáveis para a maioria dos caracteres. Quadrados médios altamente significativos para ambientes indica considerável diferença entre os mesmos e seu efeito predominante na maioria das características (Sood et al., 1999). Efeitos significativos para locais também foram reportados por Toledo et. al. (1990), Rocha (1998), Miranda (1999).

A magnitude dos quadrados médios de locais, foi geralmente maior que os de cruzamentos $\left(F_{2}\right)$ e da interação $F_{2} \times L$. Isto confirma as obsenvações feitas por Romagosa \& Fox (1993) de que, a proporção da soma de quadrados devido à variância entre locais variou de $80 \mathrm{a}$ $90 \%$ em relação à soma de quadrados da variação total; os autores também identificaram que a interação $G \times L$ foi freqüentemente maior (20\%) que o efeito principal de genótipos (10\%); eles concluiram que, como os genótipos tendem a ser mais divergentes, assim como os locais, a interação $\mathrm{G} \times \mathrm{L}$ tende a aumentar facilmente até 40 a $60 \%$ da variação total. A correta escolha dos ambientes de avaliação permite reduzir a magnitude das interações e, assim, aumenta a herdabilidade, o que por sua vez, tem influência na pressão de seleção e ou no ganho genético.

Os CVs obtidos na análise de conjunta de variância (Tabela 3.7) mostraram, a exemplo das análises individuais, menores valores para NDM, NDF, \%OL e VA; valores intermediários para APF e APM; e, maiores valores para PO e PG. Isto implica em maior e menor estabilidade para NDM e PG, respectivamente. Tal estabilidade está intimamente relacionada com o tipo de herança genética apresentado por tais caracteres, sendo relativamente simples para NDM e \%OL e bastante complexa para PG e PO. Este último caráter, depende dos caracteres \%OL e PG, sendo mais influenciado por PG (Lainez-Mejia, 1996). Os coeficientes de determinação ( $\left.R^{2}\right)$ variaram de 0,75 a 0,98 , sendo superiores às análises individuais, novamente, os caracteres PG, \%OL e PO mantiveram-se com os menores valores na análise conjunta.

A significância da interação $T \times L$ indica que os efeitos dos tratamentos e locais não explicam toda a variação encontrada nos caracteres avaliados, em conseqüência de comportamentos diferenciais dos tratamentos nos locais estudados. Isso mostra que os 
resultados são mais confiáveis e verdadeiros quando as avaliações são feitas em mais de um local; lembrando que as gerações iniciais $\left(F_{2}, F_{3}\right)$ possuem grande variabilidade, então, quanto menor a interferência da interação, maior será a segurança na obtenção das estimativas dos componentes de variância genética e dos parâmetros que dependem desta estimativa.

\subsubsection{Análise de médias}

As médias gerais dos parentais e cruzamentos $F_{2}$ são mostradas nas Tabelas 3.8 e 3.9. Observou-se que os parentais Hartwig (1) e USP 5-19 (6) foram os mais precoces, para NDF nos dois locais, seguidos pelos cruzamentos Hartwig x USP 2-16 (1 x 4), Hartwig x USP 5$19(1 \times 6)$ e Hartwig $\times$ USP $1-11(1 \times 3)$.

Quanto ao caráter APF, os parentais mostraram maiores alturas em relação aos cruzamentos, podendo-se destacar Conquista e MTBR 123.800 e os cruzamentos Conquista $x$ USP 1-11 (2 × 3), Conquista x MTBR $123.800(2 \times 5)$ e Conquista x USP 5-19 $(2 \times 6)$.

Quanto à precocidade (NDM), pode-se destacar o parental Hartwig nos dois locais $e$ USP 2-16 apenas em Anhembi. Quanto aos cruzamentos Hartwig x USP 2-16 (1 x 4), Hartwig x USP 5-19 $(1 \times 6)$ e USP 2-16 x USP 5-19 $(4 \times 6)$ foram os mais precoces nos dois locais, destacando-6e o cruzamento Hartwig x USP 1-11 (1 x 3) na ESALQ e o USP 1-11 x USP 2-16 (3 x 4) em Anhembi. Quanto ao caráter APM, os cruzamentos apresentaram alturas superiores à maioria dos parentais apenas na ESALQ. Os cruzamentos Conquista x USP 1-11 $(2 \times 3)$ e USP 1-11 x USP 2-16 (3 x 4) destacaram-se nos dois locais. Já os cruzamentos USP 1-11 x MTBR $123.800(3 \times 5)$ e USP $1-11 \times$ USP 5-19 $(3 \times 6)$ tiveram destaque apenas na ESALQ, enquanto USP 2-16 x MTBR 123.800 (4 x 5) em Anhembi.

Quanto ao VA, nota-se poucas diferenças em termos de parentais e cruzamentos. $\mathrm{Na}$ ESALQ, os cruzamentos envolvendo Conquista e USP 1-11 apresentaram as maiores notas para VA; já em Anhembi a diferença foi muito pequena, destacando-se os cruzamentos envolvendo 0 parental Conquista e os cruzamentos USP 1-11 x MTBR $123.800(3 \times 5)$ e USP 2-16 $\times$ MTBR123.800 (4 × 5).

No caráter $P G$, os cruzamentos mais produtivos variaram conforme 0 local e nenhum cruzamento superou o parental mais produtivo (MTBR 123.800); no entanto, pode-se destacar os 
cruzamentos Conquista $\times$ USP 1-11 $(2 \times 3)$, Conquista $\times$ USP 2-16 $(2 \times 4)$ e Conquista $\times$ MTBR $123.800(2 \times 5)$, pois os mesmos apresentaram elevada produtividade nos dois locais. Em Anhembi, os destaques foram: USP 2-16 x MTBR 123.800 ( 4 × 5).

0 caráter \%OL revelou a existência de pouca variabilidade nos dois locais, apresentando maiores valores na ESALQ. No geral, pode-se destacar o parental USP 2-16 na ESALQ e os cruzamentos Hartwig x USP 1-11 (1 x 3), USP 1-11 x USP 2-16 (3 x 4), USP 1-11 x USP 5-19 $(3 \times 6)$ com os maiores valores nos dois locais. Baixa variabilidade para $\%$ OL entre os genótipos também foi obtida por Rocha (1998) e Soldini (1998). No geral, houve concordância entre PG e PO nos dois locais, confirmando os relatos de Lainez-Mejia (1996) de que o caráter $\mathrm{PO}$ é mais influenciado por PG. Para o caráter PO, nos dois locais, destacaram-se os seguintes cruzamentos: Hartwig x USP 1-11 (1 × 3), Conquista x USP 1-11 ( $2 \times 3$ ), Conquista x USP 2-16 (2 $x$ 4) e USP 1-11 x USP 2-16 (3 x 4). Na ESALQ, o destaque foi USP 1-11 x USP 2-16 (3 $\times 4)$. Já em Anhembi o maior destaque foi USP 2-16 x MTBR $123.800(4 \times 5)$.

$O$ teste de Scott-Knott $(p<0,05)$ revelou a existência de maiores diferenças entre parentais e entre cruzamentos $F_{2}$ para os caracteres NDF e APF, evidenciando a existência de variabilidade nos mesmos. Os cruzamentos Conquista $\times$ USP 1-11 $(2 \times 3)$ e Conquista $\times$ USP 216 ( 2 x 4) na ESALQ e USP 2-16 x MTBR 123.800 (4 x 5) e Conquista x USP 2-16 (2 x 4) em Anhembi destacaram-se oomo os mais divergentes para PG e PO.

De forma geral, os cruzamentos que envolveram os parentais Conquista (2), USP 1-11 (3) e USP 2-16 (4), tiveram bom desempenho para vários caracteres, dentre eles NDM, VA, PG e PO. Merecem destaque os cruzamentos Hartwig x USP 1-11 (1 x 3), Conquista x USP 1-11 ( 2 x 3), Conquista x USP 2-16 ( $2 \times 4$ ) e USP 2-16 x MTBR 123.800 ( 4 × 5) com altos valores para todas as características nos dois locais.

\subsubsection{Correlações fenotípicas, genotípicas e ambientais}

Embora tenha sido possivel acrescentar niveis de significância estatistica às estimativas de correlações fenotipicas, genotipicas (Tabelas 3.10 e 3.11), existe uma tendência entre os melhoristas de plantas de se valorizar mais o sinal (positivo ou negativo) e a magnitude 
dos valores na interpretação aplicada das correlações. Nesse sentido, um critério comum é valorizar as estimativas abaixo de -0,5 e acima de 0,5.

De acordo com as Tabelas 3.10 e 3.11, as correlações genotípicas tiveram o mesmo sinal e foram maiores que as fenotipicas e ambas, geralmente, superaram as respectivas correlações de ambiente, indicando que a expressão dos caracteres deve ser menos influenciada pelas condições ambientais. No entanto, as correlações entre NDM e APM, \%OL e PO, para F2 nos dois locais e entre \%OL e PO para parentais na ESALQ, bem como a correlação entre APM e APF para parentais nos dois locais, mostraram que a ação dos locais atuou no mesmo sentido na expressão desses caracteres e foi relativamente mais importante que a ação dos genótipos na associação entre eles.

Correlações genotípicas com sinal igual e valores maiores que as fenotípicas tem sido comuns em soja (Freire Filho, 1988; Moro et al., 1992; Soldini, 1993; Taware et al., 1997). Embora sendo os parentais homozigóticos e os $F_{2}$ heterozigóticos, as correlações genotípicas e fenotípicas foram bastante concordantes nos dois grupos.

Considerando os dois locais e apenas os cruzamentos $F_{2}$, 0 caráter PG mostrou correlações fenotípicas e genotípicas positivas e altas para a maioria dos demais caracteres, com exceção de \%OL. Zimback (1992) obteve correlação negativa e baixa entre PG e \%OL, tanto para a geração $F_{2}$ quanto para o grupo de parentais; esses resultados concordam com os obtidos neste trabalho apenas para $F_{2}$; já para os parentais, os sinais foram opostos, sendo positivo e baixo na ESALQ e negativo e alto em Anhembi. Montaño-Velasco (1994) encontrou resultados semelhantes para parentais. Pode-se ainda destacar as correlações genotípicas positivas e altas de PG com VA e de PG com PO nos dois locais. No primeiro caso, há evidências de que VA é bastante útil no processo de avaliação preliminar e que, embora seja um caráter subjetivo, 0 mesmo é bastante eficiente na seleção dos melhores genótipos. Pushpendra \& Ram (1990) citam que a seleção visual para produtividade tem se mostrado eficiente em gerações iniciais, comprovando o fato de que a maior capacidade produtiva atribui maiores notas de VA. No segundo caso, já era esperada uma correlação positiva e alta entre PG e PO, pois o caráter PO é função direta de PG. Segundo Soldini (1998) a contribuição para a correlação em PO è dada principalmente por PG, como conseqüência da baixa variabilidade genética existente para \%OL. 
De acordo com Laínez-Mejía (1996), para que PO se torne um caráter de importância comercial é preciso que hajam mudanças nas freqüências alélicas para capacidade produtiva de grãos.

As Tabelas 3.10 e 3.11 também indicam que os caracteres NDF e APF, nos dois locais e envolvendo parentais e $F_{2}$, apresentaram correlações fenotipicas e genotipicas positivas e altas entre a maioria dos caracteres, com exceção das correlações com \%OL que foram negativas. Os caracteres relacionados com 0 desenvolvimento da planta na maturidade (NDM e APM) apresentaram correlações fenotípicas e genotípicas positivas e altas com a maioria dos caracteres, exceto entre NDM e \%OL para parentais e $F_{2}$ na ESALQ; já em Anhembi, as exceções foramentre NDM e \%OL para parentais e $F_{2}$ e entre APM e \%OL para parentais. Podese ainda destacar as correlações altas e positivas entre NDM e PG e também entre APM e PG; quanto maior o ciclo da planta, mais ela cresce e, com isso, aumenta o número de internódios produtivos, levando a uma correlação positiva. Esses resultados sugerem que nesse grupo de genótipos, os caracteres avaliados no florescimento e na maturidade, em época normal de cultivo, parecem ter grande importância no processo de seleção. Outros trabalhos também destacam a importância destes caracteres. Cecon et al. (1993) obtiveram correlação genotipica positiva e significativa entre dias para maturação e altura da planta na maturidade $\left(r_{G}=0,704\right)$, enquanto que Morrison et al. (2000) encontraram correlação fenotipica positiva e baixa $(0,037)$.

$O$ caráter VA também apresentou correlações fenotipicas e genotipicas positivas e altas para a maioria dos caracteres, com exceção de \%OL, que apresentou mudanças tanto na magnitude das correlações como nos sinais, variando de acordo com o local e o tratamento $\left(F_{2} e\right.$ parentais). Na ESALQ, as correlações fenotipicas e genotipicas foram positivas e baixas (parentais e $F_{2}$ ) e somente a fenotipica foi negativa entre VA e \%OL para $F_{2}$. Em Anhembi, as correlações fenotipicas e genotipicas foram negativas e altas apenas entre VA e \%OL. O caráter \%OL apresentou correlações fenotipicas e genotipicas negativas e altas para a maioria dos caracteres com exceção da APM ( $F_{2}$ na ESALQ e Anhembi) e APM, VA, PG e PO (parentais na ESALQ). Com relação ao caráter PO, as correlações fenotipicas e genotipicas foram positivas e altas, para parentais e $F_{2}$, para todos os demais caracteres apenas na ESALQ. Em Anhembi, as correlações fenotipicas e genotipicas foram positivas e altas para a maioria dos caracteres, exceto para \%OL. 
Conforme pode ser observado nas Tabelas 3.10 e 3.11, tanto nos parentais quanto nos cruzamentos $F_{2}$, há casos de diferenças de sinal nas correlações fenotípicas, genotípicas e de ambiente. Quando correlações de ambiente apresentam sinais contrários ao das correlações fenotípicas e genotípicas, sugere que a ação dos locais foi em sinal contrário ao da ação dos genótipos nesses caracteres. Na prática, isso é muito importante porque, dependendo da magnitude da ação do ambiente pode comprometer a eficiência da seleção. Falconer \& Mackay (1996) cita ainda que a diferença de sinal entre as correlações genotipicas e de ambiente pode ser atribuída às causas de variação herdável e de ambiente que afetam dois caracteres através de diferentes mecanismos fisiológicos.

Uma limitação apontada pela correlação entre NDM e PG é a dificuldade de reunir em um mesmo genótipo os genes favoráveis para produtividade e para precocidade. Isso se deve às causas genéticas das correlações entre caracteres: a) ligação genética entre os genes que controlam dois caracteres, dificil de ser superado (quebrado) quando muito forte (c $\leq 10 \%$ de recombinação), podendo, neste caso, até impedir o aparecimento de recombinantes desejáveis nas gerações filiais; b) pleiotropia, ou seja, o (s) mesmo (s) genes controlam os dois caracteres; neste caso a possibilidade de obtenção de recombinantes fica restrita a ocorrência de mutações espontâneas e ou induzidas. Quando se trata de ligação, os valores da correlação podem variar de $-1,0$ a 1,0, dependendo da distância genética entre os genes. Já no caso de pleiotropia a correlação é muito alto, próxima de $-1,0$ ou de 1,0 para o caso de um gene. Portanto, correlações no intervalo de $-1,0<\mathrm{r}<-0,5$ e $0,5<\mathrm{r}<1,0$ são dificeis de serem suplantadas, levando à classificação em caracteres associados negativa e positivamente, respectivamente.

Os demais caracteres relacionados ao florescimento e à maturidade, incluindo-se VA, mostraram-se importantes para o aumento da produtividade. Portanto, é possivel obter ganhos genéticos para produtividade mesmo em populações com genes de resistência ao nematóide de cisto da soja.

No geral, parentais e $F_{2}$ apresentaram variabilidade para todos os caracteres tanto para cada local como conjuntamente. O parental Hartwig foi o mais precoce, enquanto Conquista e MTBR123.800 foram os mais tardios . Destacaram-se os cruzamentos Conquista x USP 1-11 (2x 3), Conquista x USP 2-16 (2 × 4) e Conquista x MTBR $123.800(2 \times 5)$, com altos valores para todas as características nos dois locais. O cruzamento USP 2-16 x MTBR $123.800(4 \times 5)$ 
também se destacou para a maioria das características, apenas em Anhembi. Em termos de qualidade ambiental favorável, os dois locais foram bons para a expressão do potencial genético dos genótipos avaliados, no entanto, o local Anhembi foi mais favorável para PG. A interação genótipos $\times$ locais $(G \times L)$ mostrou-se um importante componente da variação fenotípica, com exceção do caráter \%OL $\left(F_{2} \times L\right)$. As correlações genotipicas foram geralmente maiores que as fenotípicas e de ambiente nos dois locais. A magnitude apresentada pelas correlações fenotípica e genotipica, mostra que 0 fenótipo refletiu satisfatoriamente 0 genótipo. Os caracteres relacionados ao florescimento, à maturidade e ao valor agronômico mostraram-se importantes para o melhoramento da produtividade. 
Tabela 3.1 Genealogia dos parentais envolvidos nos cruzamentos dialélicos $6 \times 6$.

\begin{tabular}{|c|c|c|}
\hline Parental & Genealogia & Descrição \\
\hline 1- Hartwig & Forrest $^{3} \times$ PI 437.654 & Cultivar exótico \\
\hline 2- Conquista & LO 75-4484 x Numbaíra & Cultivar comercial \\
\hline 3- USP 1-11 & IAC Foscarin-31 x Forrest & Linhagem Experimental \\
\hline 4- USP 2-16 & Forrest x Primavera & Linhagem Experimental \\
\hline 5- USP 5-19 & Kirby $\times$ FT-2 & Linhagem Experimental \\
\hline 6-MTBR 123.800 & Hartwig $\times[$ Padre $\times($ BR 87-567 $\times$ Tracy $-M)]$ & Linhagem Experimental \\
\hline
\end{tabular}

Tabela 3.2 Esquema da análise de variância individual em blocos ao acaso e respectivas esperanças matemáticas dos quadrados médios.

\begin{tabular}{llccc}
\hline Fontes de Variação & G.L. & $\mathrm{QM}$ & $\mathrm{E}(\mathrm{QM})$ & $\mathrm{F}$ \\
\hline Repetições (R) & $\mathrm{R}-1$ & $\mathrm{Q}_{3}$ & $\sigma_{\mathrm{e}}^{2}+l \sigma_{r}^{2}$ & $\mathrm{Q}_{3} / \mathrm{Q}_{1}$ \\
Tratamentos (T) & $\mathrm{T}-1$ & $\mathrm{Q}_{2}$ & $\sigma_{\mathrm{e}}^{2}+J \phi_{\mathrm{t}}$ & $\mathrm{Q}_{2} / \mathrm{Q}_{1}$ \\
Resíduo & $(\mathrm{R}-1)(\mathrm{T}-1)$ & $\mathrm{Q}_{1}$ & $\sigma_{\mathrm{e}}^{2}$ & \\
\hline Total & (RT)-1 & & & \\
\hline
\end{tabular}




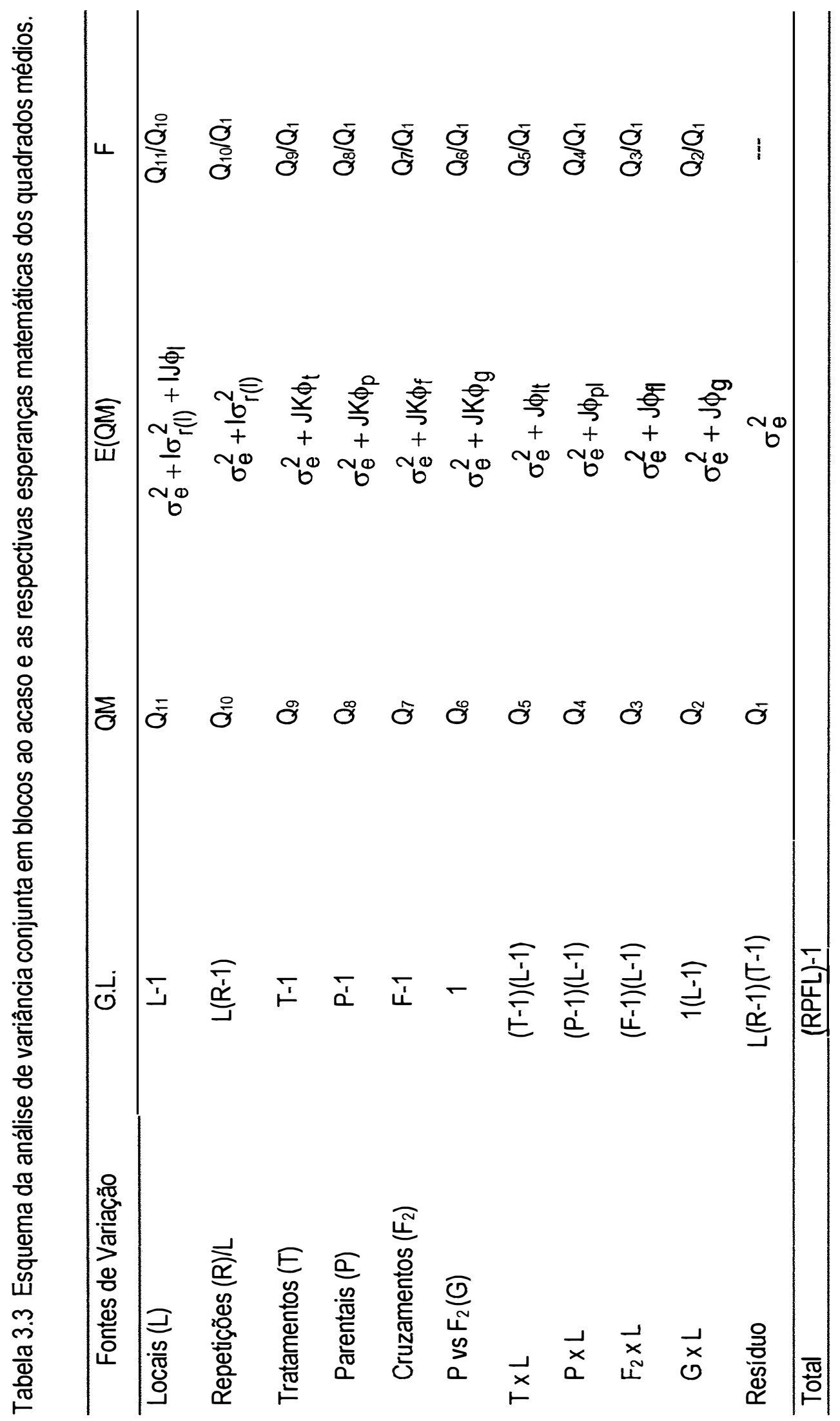




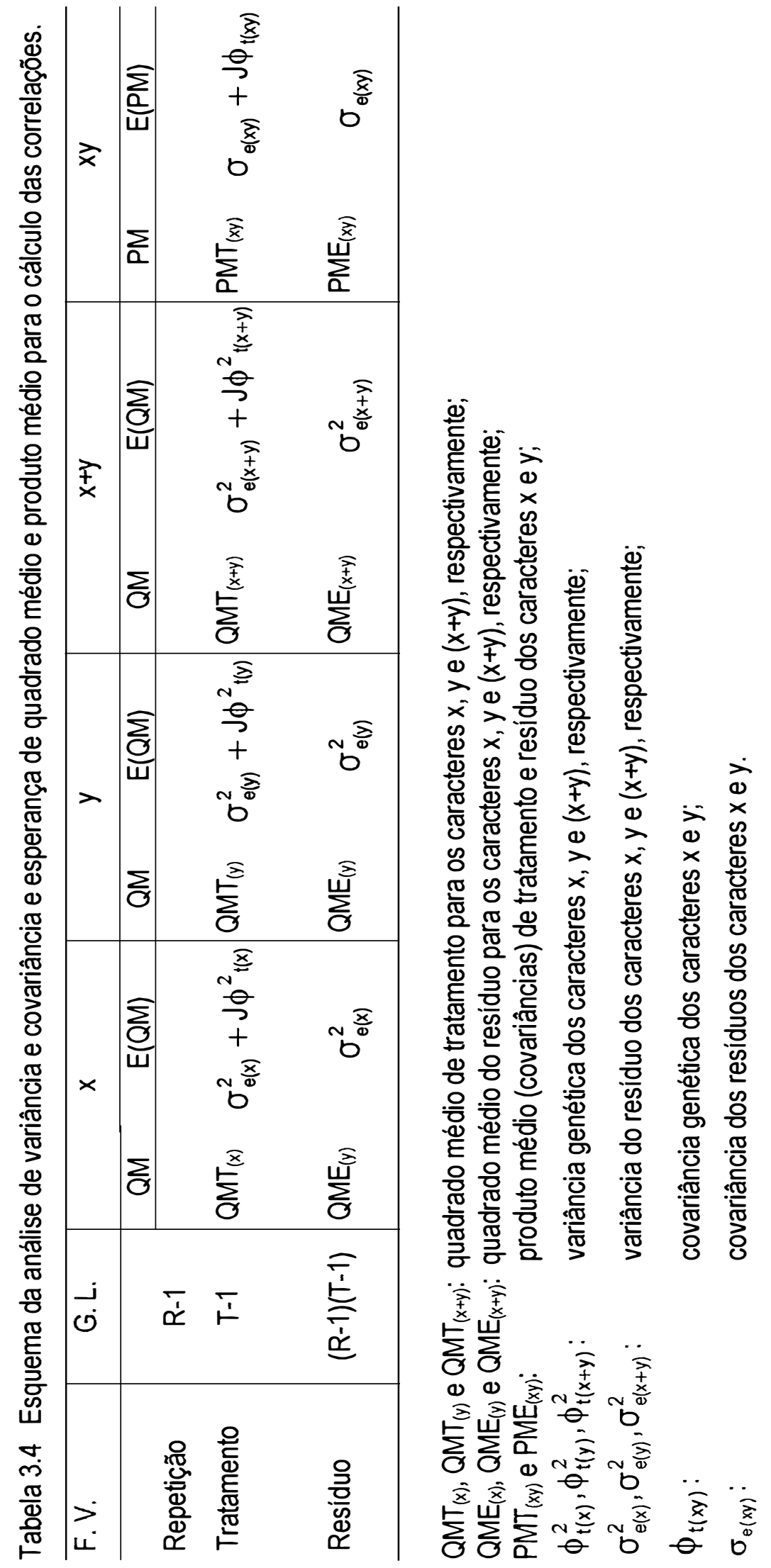




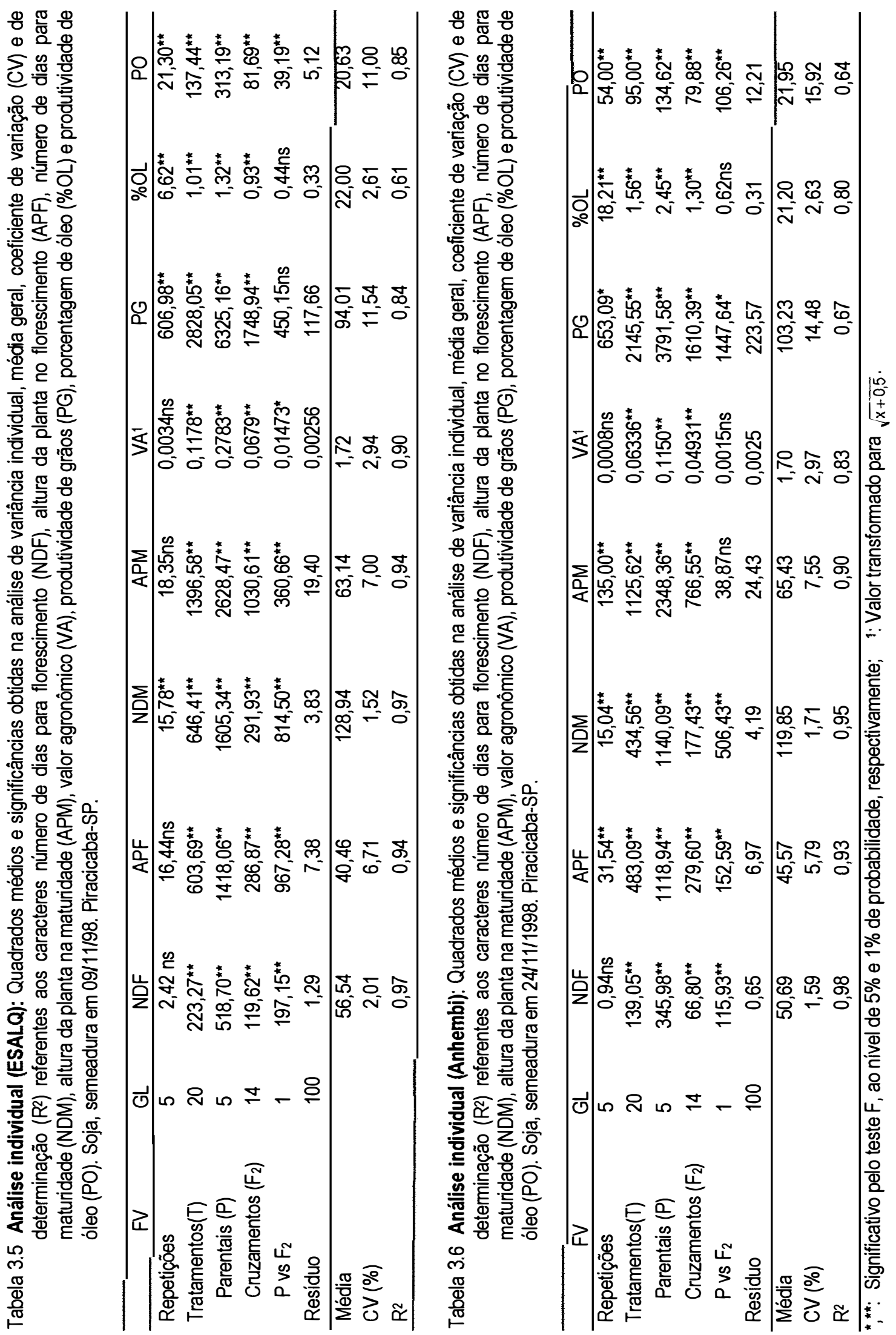




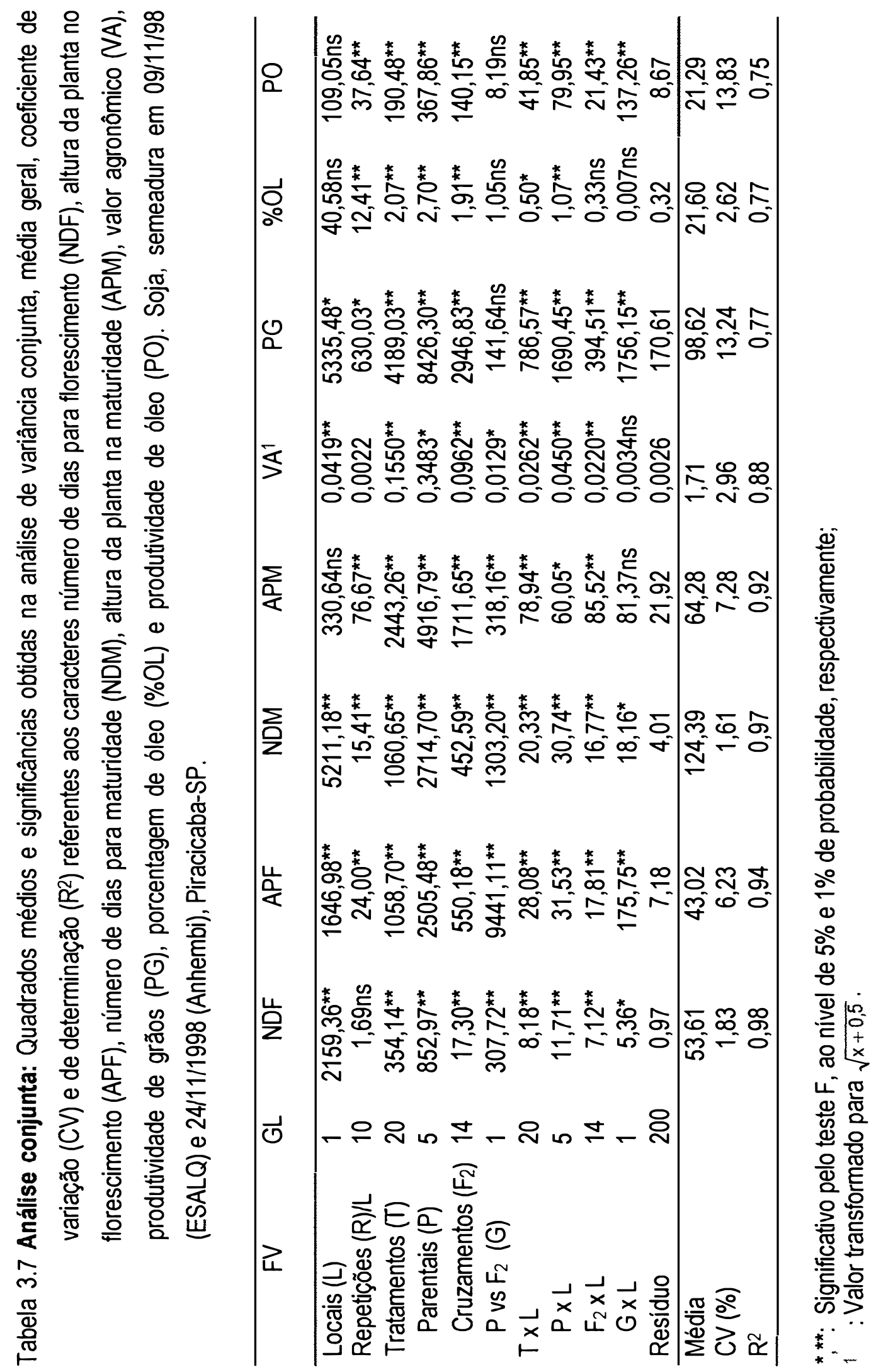




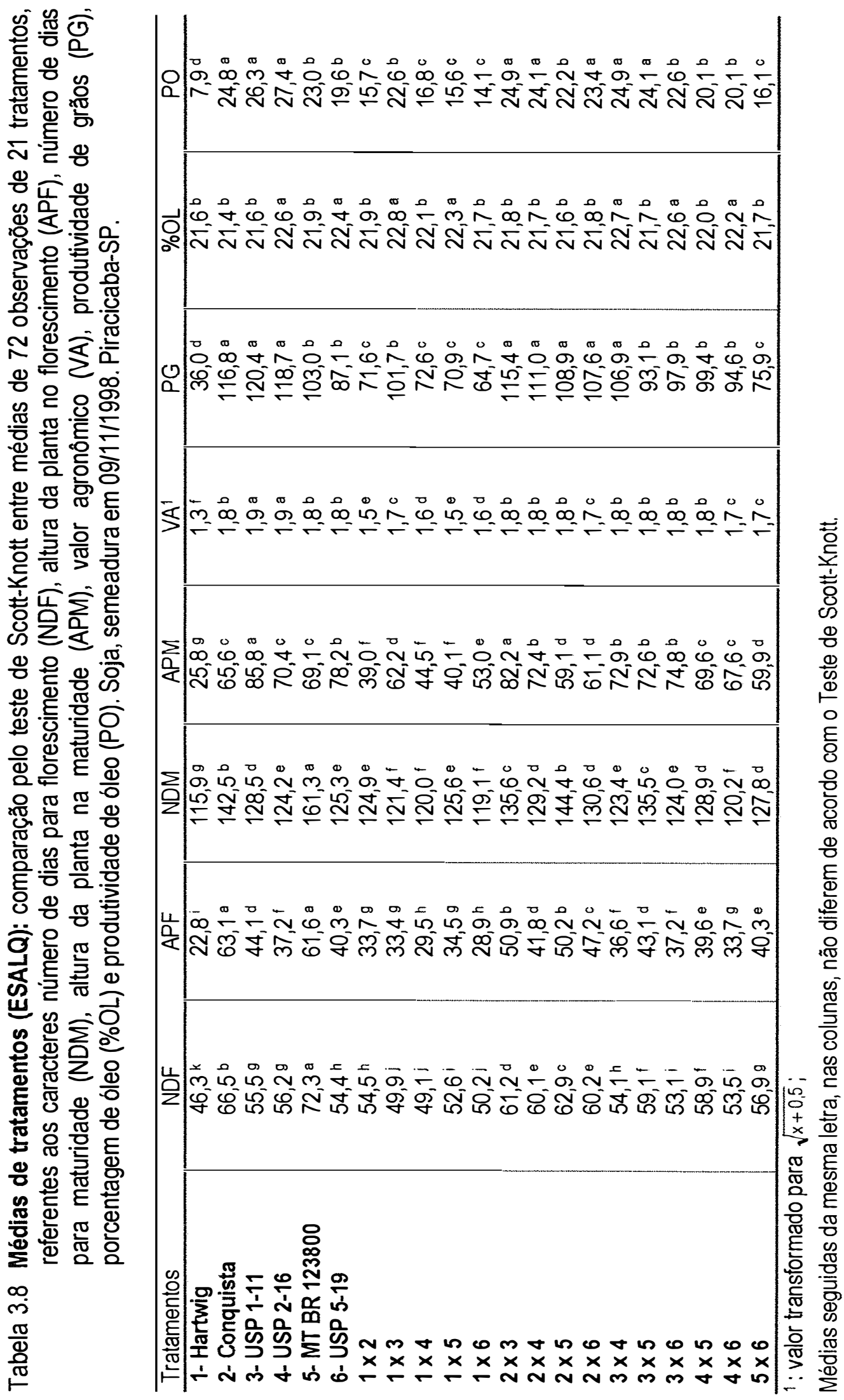




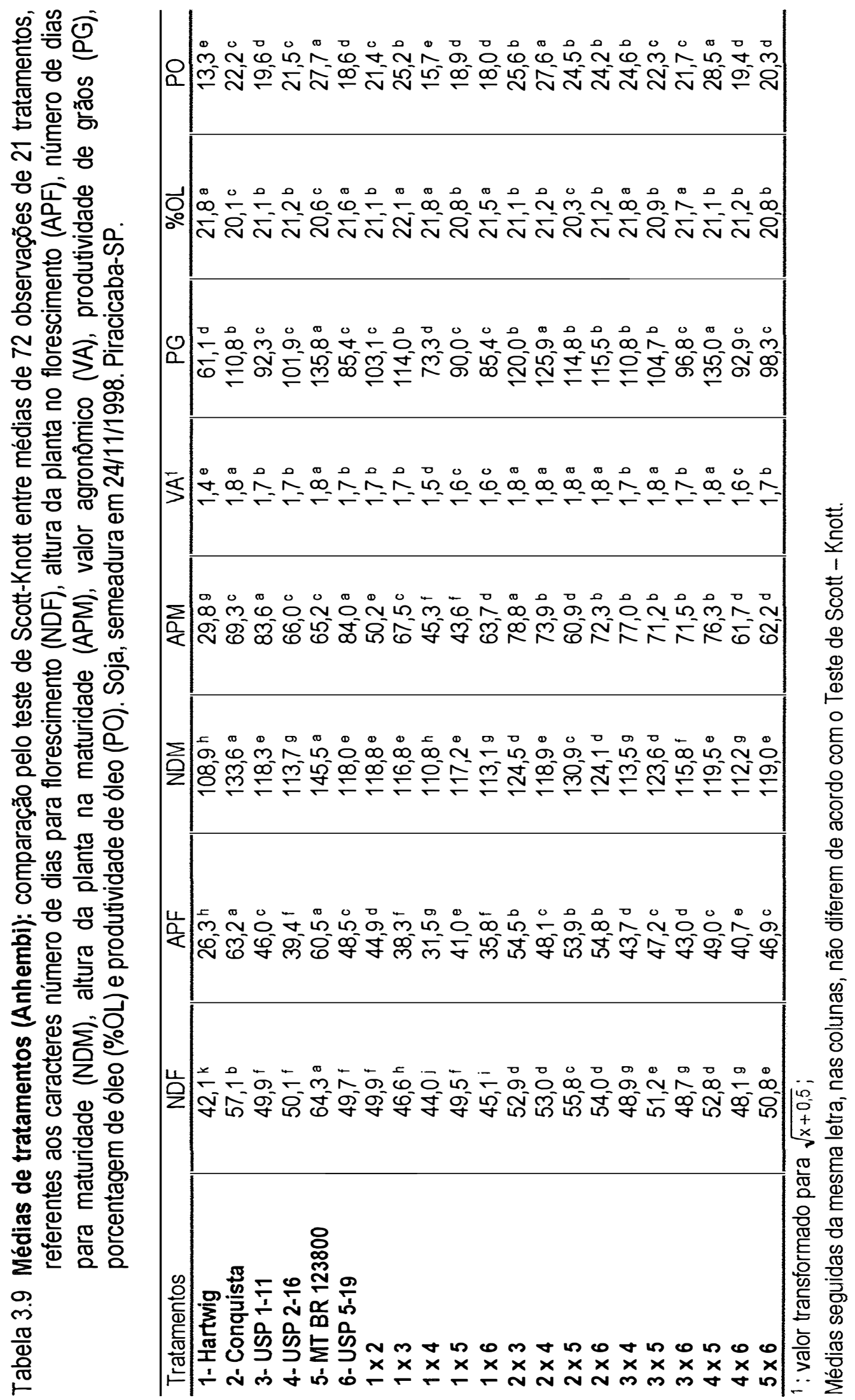




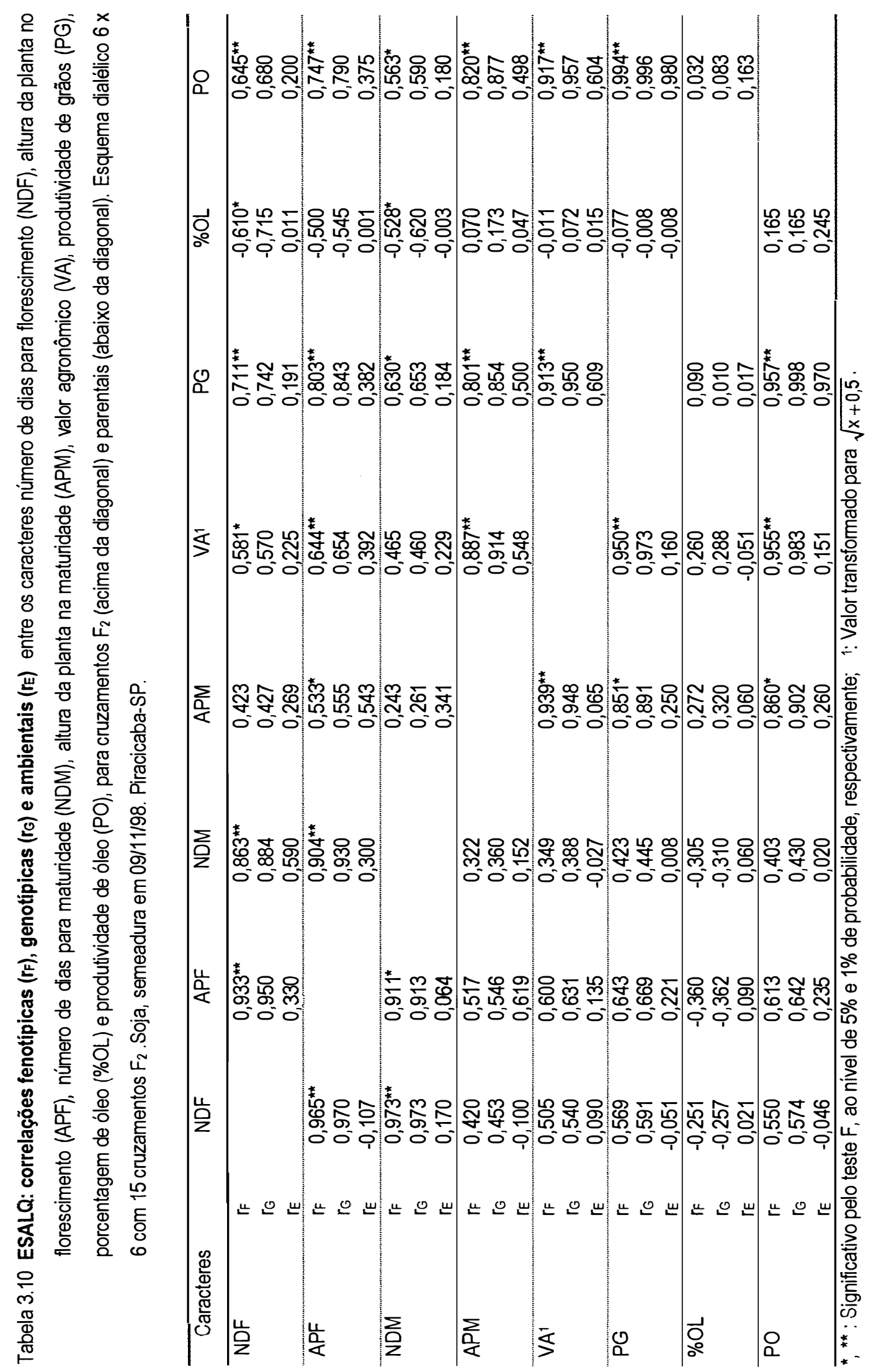




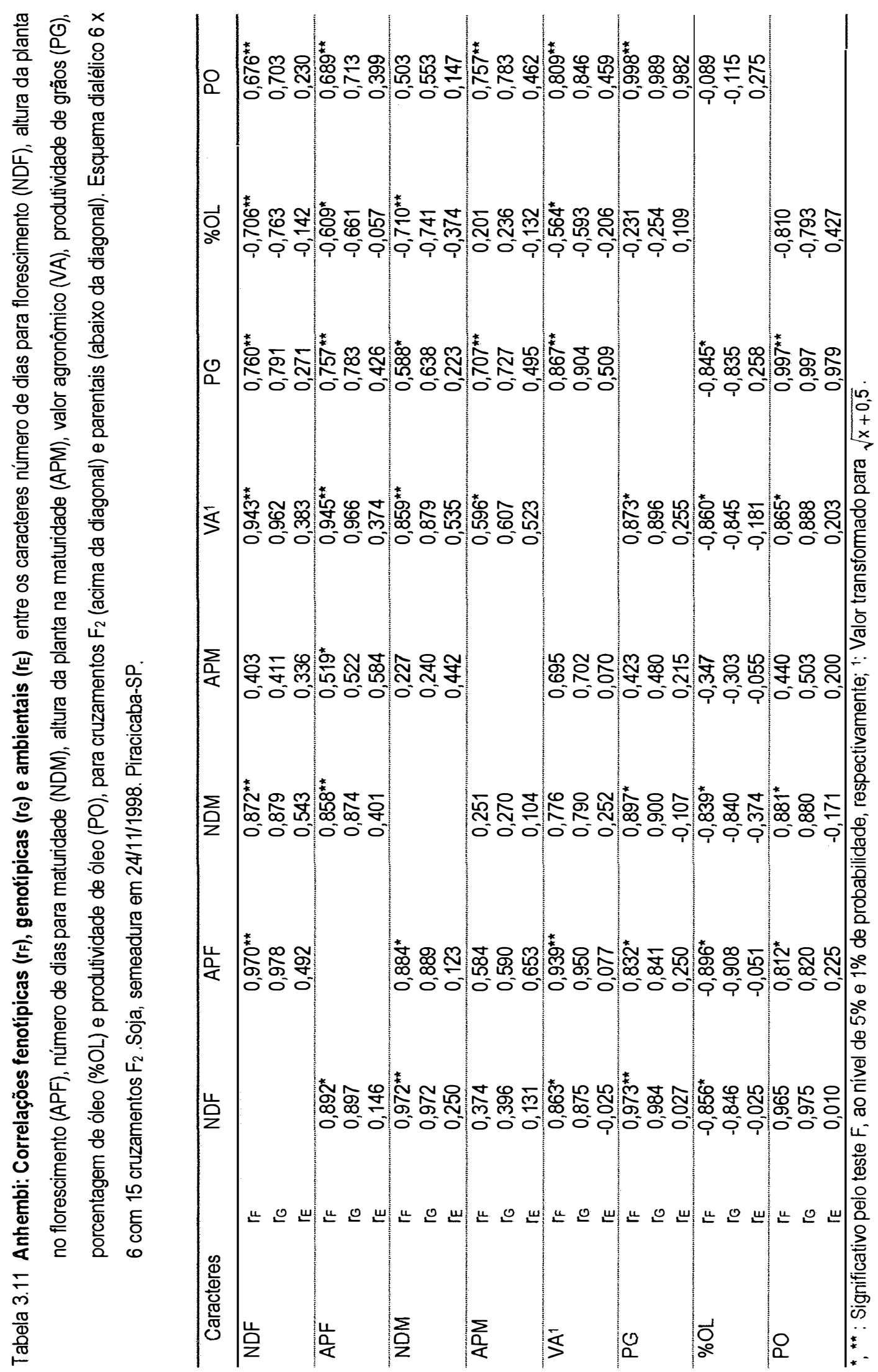




\section{ANÁLISE DA CAPACIDADE COMBINATÓRIA EM SOJA}

\section{RESUMO}

Esse estudo teve como objetivos avaliar as capacidades de combinação e suas interações com ambientes, além de identificar os cruzamentos dialélicos mais promissores entre seis parentais de soja. Os seis parentais: (1) Hartwig, (2) Conquista, (3) USP 1-11, (4) USP 2-16, (5) MTBR 123.800, (6) USP 5-19 e os 15 cruzamentos $F_{2}$ foram avaliados durante 0 ano agricola 1998/99, em experimentos delineados em blocos ao acaso, com seis repetições em cada um de dois locais: ESALQ e Anhembi. Os dois locais são contrastantes em relevo e propriedades físicas e quimicas do solo. A parcela experimental compreendeu 12 covas de plantas individuais, espaçadas de 0,80 $\mathrm{m} \times 0,80 \mathrm{~m}$. Os seguintes caracteres foram avaliados: NDF- Número de dias para o florescimento; APF- Altura da planta no florescimento; NDM- Número de dias para a maturidade; APM- Altura da planta na maturidade, VA-Valor agronômico; PG- Produtividade de grãos; \%OL - Teor de óleo nas sementes; PO - Produtividade de óleo por planta. Esses caracteres foram analisados utilizando-se uma adaptação do método 2 , modelo misto $B$ de Grifing, na qual os cruzamentos e os parentais do dialelo completo são avaliados em vários ambientes. Na análise conjunta foram detectadas diferenças altamente significativas $(p<0,01)$ para locais, capacidade geral de combinação (CGC), capacidade especifica de combinação (CEC) e para as interações CGC x Locais e CEC x Locais. Os efeitos das interações com locais $\left(\begin{array}{lll}\left(\hat{g}_{i k}\right. & \text { e } & \hat{s}_{i k}\end{array}\right)$ influenciaram a ordem de classificação dos parentais e dos cruzamentos. A diversidade genética (medida por $\mathrm{s}_{\mathrm{ii}}$ ) foi importante para o efeito da CEC dos cruzamentos. Cruzamentos entre parentais contrastantes nas estimativas de capacidade geral de combinação resultaram em elevados efeitos da CEC. Vários cruzamentos mostraram-se promissores, com destaque para Hartwig $\times$ USP 1-11 $(1 \times 3)$ com o maior efeito de $\hat{s}_{i j}$ nos dois locais. 


\section{COMBINING ABILITY ANALYSIS IN SOYBEAN}

\section{SUMMARY}

The objective of this study was to evaluate the combining ability and its interactions with environments, besides of to identify the most promising crosses among six soybean genotypes. The six parents: : (1) Hartwig, (2) Conquista, (3) USP 1-11, (4) USP 2-16, (5) MTBR 123.800, (6) USP 5-19 and the $15 \mathrm{~F}_{2}$ crosses among then were evaluated through two completely randomized block design experiments during the 1998/99 crop season, with six replications in each of two localities: ESALQ and Anhembi. The two localities are contrasting in relief, and in physical and chemical properties of the soil. The experimental plot was represented by 12 hills of individual plant spaced $0.80 \mathrm{~m} \times 0.80 \mathrm{~m}$. The following characters were evaluated: NDF - number of days to flowering; APF - plant height at flowering; NDM - number of days to maturity; APM - plant height at maturity; VA - agronomic value; $\mathrm{PG}$ - seed yield; \%OL - seed oil content; $\mathrm{PO}$ - oil yield. The traits were analysed using an adaptation of Griffing's method 2, model mixed B, for complete diallel crosses and for experiments carried out in several environments. The joint analysis of diallel data across localities showed highly significant $(p<0,01)$ effects for localities $(L)$, general combining ability (GCA), specific combining ability (SCA), and for GCA $\times L, S C A \times L$ interactions. The interaction effects with localities $\left(\left.\right|_{\mathrm{i} k}\right.$ and $\left.\mid \hat{\mathrm{s}}_{\mathrm{ikk}}\right)$ influenced the ranking of parents and crosses. The genetic diversity, as measured by the $s_{\mathrm{ii}}$ parental parameter, was important for the SCA among crosses. High values of SCA were stimated in crosses between parents contrasting in the GCA effect. Several crosses were promising. The Hartwig x USP 1-11 (1 $\times 3$ ) cross exceeded with high values of $\hat{\mathrm{s}}_{\mathrm{ij}}$ in both localities. 


\subsection{INTRODUÇÃO}

A cultura da soja ocupa uma posição de destaque no setor agricola brasileiro, sendo cultivada em todas as regiões brasileiras, desde as tradicionais Sul e Sudeste até as mais recentes Centro-Oeste, Nordeste e Norte. Essa ampla ocupação necessita de cultivares bem adaptados às diferentes condições agro-climáticas e para que esses cultivares sejam obtidos é preciso que as fases iniciais dos programas de melhoramento sejam bem desenvolvidas. Dentre estas, pode-se destacar a "seleção de parentais" como um dos aspectos mais críticos, uma vez que o sucesso do programa depende diretamente desta etapa.

Tradicionalmente, os trabalhos de melhoramento genético de soja têm utilizado a sintese de cruzamentos biparentais e a condução das populações segregantes até a homozigose, através de diferentes metodologias, objetivando disponibilizar a variabilidade genética até a abertura de linhagens, para seleção das melhores, e obtenção de novos cultivares. No entanto, comumente, os melhoristas encontram dificuldades quando precisam selecionar parentais e cruzamentos com objetivo de identificar aqueles que possam produzir progênies com alto potencial de rendimento. Nesse contexto, os cruzamentos dialélicos mostram-se bastante eficientes, pelo fato de avaliarem as populações "per se" e suas combinações hibridas.

A natureza e a magnitude da capacidade de combinação, obtidas pela análise dialélica, auxilia na identificação dos melhores parentais e das combinações mais desejáveis, que é de imenso valor na formulação de qualquer programa de melhoramento, mesmo em espécies como a soja que possui um certo grau de dificuldade para a realização dos cruzamentos. Os métodos de estudo dialélico têm por finalidade analisar o delineamento genético, fornecendo estimativas de parâmetros que são utilizados na seleção de parentais para hibridação e no entendimento dos efeitos gênicos envolvidos na determinação dos caracteres que compõem os objetivos do programa de melhoramento (Cruz \& Regazzi, 1994).

Os termos capacidade geral de combinação (CGC) e capacidade especifica de combinação (CEC) foram definidos pela primeira vez por Sprague \& Tatum (1942) e representam o comportamento de genótipos em cruzamentos. A CGC caracteriza o comportamento médio de 
um genótipo em uma série de combinações hibridas e está mais associada à ação aditiva dos genes. A CEC é usada para caracterizar o comportamento de combinações hibridas especificas em relação à média dos genitores e é associada predominantemente à ação dominante dos genes. Ramalho et al. (1993) também citam a CGC como parâmetro de maior importância prática para o melhorista, uma vez que, a partir dela pode-se obter informações sobre a participação dos efeitos aditivos dos genes na amplitude da variação das gerações segregantes de um dado cruzamento, permitindo traçar as melhores estratégias para o programa de melhoramento.

Inicialmente, estes estudos foram realizados com espécies alógamas; no entanto, também tem sido explorado em espécies autógamas, devido ao valor prático para estudos genéticos e para seleção de parentais. Em soja, a metodologia apresentada por Griffing (1956a) é bastante usada. Esta metodologia, que estima as capacidades geral e especifica de combinação dos parentais em cruzamentos dialélicos, foi desenvolvida para quatro tipos de tabelas dialélicas, correspondendo a quatro métodos, podendo-se destacar o método 2, em que são usados os parentais e $F_{1}$ sem reciprocos e no método 4 é usado apenas o conjunto $F_{1}$, sem parentais e sem reciprocos. Deve-se ressaltar que ambos têm sido empregados também em $\mathrm{F}_{2}$ (Freire Filho, 1988; Nass, 1989; Pimentel, 1991; Sharma \& Phul, 1994; Pulcinelli, 1997; Soldini, 1998; Gadag et al., 1999).

Para se obter informações mais consistentes, é importante a condução de ensaios dialélicos repetidos em vários ambientes (locais, anos, épocas de cultivo). A análise conjunta desses ensaios inclui além das fontes de variação encontradas nas análises individuais, as interações dos efeitos principais com os ambientes. Singh (1973a,b, 1979), Oliveira et al. (1987), Morais et al. (1991), Ferreira et al.(1993) desenvolveram metodologias de análise conjunta de ensaios dialélicos conduzidos em vários ambientes. Para o caso dos cruzamentos dialélicos em soja pelo método de Griffing , envolvendo parentais e $F_{2}$, não se encontram muitas referências sobre a análise conjunta desses ensaios quando repetidos em vários ambientes (Paschal \& Wilcox, 1975; Sharma et al., 1993).

O presente trabalho teve os seguintes objetivos: avaliar a capacidade geral de combinação de seis parentais de soja e indicar suas possiveis combinações superiores avaliadas em dois locais. 


\subsection{MATERIAL E MÉTODOS}

\subsubsection{Material genético}

Seis genótipos de soja: (1) Hartwig, (2) USP 1-11, (3) Conquista, (4) USP 2-16, (5) MT BR 123.800 e (6) USP 5-19 foram cruzados em dialelo completo sem reciprocos. Estes parentais foram escolhidos pela produtividade de grãos, desempenho agronômico e resistência a doenças (Tabela 3.1, capitulo 3). Os experimentos foram conduzidos, na safra de 1998/99, em dois locais, ESALQ e Anhembi, localizados no municipio de Piracicaba-SP, a $22^{\circ} 42^{\prime} 30^{\prime \prime}$ de latitude Sul, $47^{\circ} 39^{\prime} 00^{\prime \prime}$ de longitude Oeste e $543 \mathrm{~m}$ de altitude. Os dois locais são bem contrastantes: ESALQ - área localizada no Departamento de Genética, apresenta solo do tipo terra roxa estruturada, textura argilosa, relevo ondulado; Estação Experimental Anhembi - caracterizado por solo aluvial distrófico, textura médio-arenosa, relevo plano, situado cerca de $60 \mathrm{~km}$ da sede ESALQ.

Os 21 tratamentos foram constituidos por seis parentais e 15 cruzamentos $F_{2}$, avaliados no delineamento experimental de blocos ao acaso com seis repetições por local (ESALQ e Anhembi). A parcela foi representada por 12 covas de plantas individuais espaçadas de $0,80 \mathrm{~m} \times 0,80 \mathrm{~m}$, totalizando uma área útil de 7,68 m²; no total de seis repetições e dois locais foram pesquisadas 144 plantas $F_{2}$ de cada cruzamento. A semeadura foi realizada no mês de novembro (época normal de plantio para o Estado de São Paulo), sendo semeadas 12 sementes por cova e após 15 dias foi realizado o desbaste para uma planta por cova.

\subsubsection{Caracteres avaliados}

A partir dos dados coletados de plantas individuais foram avaliados os mesmos caracteres citados na parte referente a material e métodos do capitulo 3. Da mesma forma para os caracteres auxiliares. 


\subsection{ANÁLISES ESTATISTICO-GENÉTICAS}

\subsubsection{Análises individual e conjunta}

Foram realizadas análises de variância individuais e conjuntas no delineamento de blocos casualizados. Os modelos matemáticos utilizados para a análise de variância individual e conjunta constam no capitulo 3.

\subsubsection{Análises dialélicas}

\subsubsection{Análise dialélica por local}

Nessa análise foram usados seis parentais e seus 15 cruzamentos $F_{2}[n(n-1) / 2]$, não tendo sido incluidos os cruzamentos reciprocos (Tabela 4.1).

Com base no procedimento de escolha dos parentais e no material disponivel para 0 estudo foi utilizado para a análise o método 2 e o modelo misto $B$, desenvolvidos por Griffing (1956a). Nesse modelo os efeitos de tratamentos são fixos e os de bloco e erro experimental são aleatórios. Os efeitos de tratamentos sendo fixos implicam que as inferências são válidas somente para o material experimental usado. Neste caso, segundo Griffing (1956a), os objetivos básicos do estudo são: a) comparação da capacidade de combinação dos parentais quando eles próprios são usados como testadores e b) identificação das melhores combinações híbridas.

Para a análise da capacidade de combinação foi utilizado o mesmo modelo da análise de variância, fazendo-se 0 desdobramento dos efeitos de tratamentos em capacidade geral de combinação (CGC) e capacidade específica de combinação (CEC).

\subsection{Descrição do Modelo (Griffing 1956a)}

$$
Y_{i j k}=u+g_{i}+g_{j}+s_{i j}+\frac{1}{b} \sum_{k-1}^{b} e_{i j k}
$$

u: média geral do dialelo; 
gi: efeito da CGC do parental i;

g: efeito da CGC do parental j;

$\mathrm{sii}$ : efeitos da CEC para o cruzamento entre os parentais i e j, para o caso dos parentais

$$
\mathrm{s}_{\mathrm{ij}}=\mathrm{s}_{\mathrm{ii}}=\mathrm{s}_{\mathrm{ii}} \text {; }
$$

$\mathrm{i}, \mathrm{j}: 1,2,3, \ldots, \mathrm{n}$;

$k: 1,2,3, \ldots b$;

Para que esse modelo seja válido, são impostas as seguintes restrições:

$e_{i j k}$ : deve ter distribuição normal e ser independentemente distribuido NID $\left(0, \sigma_{\mathrm{e}}^{2}\right)$, isto é,

$$
\begin{aligned}
& E\left(e_{i j}\right)=0 \text { e } E\left(e_{i j}^{2}\right)=\sigma_{e}^{2} ; \\
& \sum_{i=1}^{n} \hat{g}_{i(j)}=0 ; \\
& \sum_{j} \hat{s}_{i j}+\hat{s}_{i i}=0 \text { para cada } i .
\end{aligned}
$$

\subsection{Estimação de Parâmetros}

Os efeitos da média, CGC e CEC foram estimados através das seguintes expressões, respectivamente:

$$
\begin{aligned}
& \hat{\mu}=\frac{2}{n(n+1)} Y_{. . ;} \\
& \hat{g}=\frac{1}{n+2}\left(Y_{i .}+Y_{i i}-\frac{2}{n} Y_{. .}\right) ; \\
& \hat{s}=Y_{i j}-\frac{1}{n+2}\left(Y_{i .}+Y_{i i}+Y_{. j}+Y_{i j}\right)+\frac{2}{(n+1)(n+2)} Y_{. .} ;
\end{aligned}
$$

As variâncias do efeito da média e dos efeitos e das diferenças entre os efeitos da CGC e da CEC foram estimadas pelas seguintes expressões:

$$
\hat{\operatorname{Var}}(\hat{\mu})=\frac{2}{n(n+1)} \hat{\sigma}_{\mathrm{e}}^{2} ;
$$


$\hat{\operatorname{Var}}\left(\hat{g}_{1}\right)=\frac{n-1}{n(n+2)} \hat{\sigma}_{e}^{2}$

$\hat{\operatorname{Var}}\left(\hat{\mathrm{s}}_{\mathrm{ii}}\right)=\frac{\mathrm{n}(\mathrm{n}-1)}{(\mathrm{n}+1)(\mathrm{n}+2)} \hat{\sigma}_{\mathrm{e}}^{2}$;

$\hat{\operatorname{Var}}\left(\hat{s}_{i j}\right)=\frac{n^{2}+n+2}{(n+1)(n+2)} \hat{\sigma}_{e}^{2}$, para $i \neq j ;$

$\hat{\operatorname{Var}}\left(\hat{g}_{i}-\hat{g}_{j}\right)=\frac{2}{n+2} \hat{\sigma}_{e}^{2}$, para $i \neq j ;$

$\hat{\operatorname{Var}}\left(\hat{s}_{i j}-\hat{s}_{j j}\right)=\frac{2(n-2)}{n+2} \hat{\sigma}_{e}^{2}$, para $i \neq j ;$

$\hat{\operatorname{Var}}\left(\hat{s}_{i i}-\hat{s}_{i j}\right)=\frac{2(n+1)}{n+2} \hat{\sigma}_{e}^{2}$, para $i \neq j$ e $j \neq j ;$

$\hat{\operatorname{Var}}\left(\hat{s}_{i i}-\hat{s}_{i j^{\prime}}\right)=\frac{2 n}{n+2} \hat{\sigma}_{e}^{2}$, para $i \neq j, i^{\prime}, j^{\prime}, j \neq i^{\prime}, j^{\prime}$ e $i \neq j^{\prime}$.

Além dessas variâncias, para a média de qualquer parental ou cruzamento $F_{2}$, tem-se que:

$$
\hat{\operatorname{Var}}\left(\mathrm{x}_{\mathrm{ij}}\right)=\hat{\sigma}_{\mathrm{e}}^{2}=\mathrm{QM}_{\mathrm{e}}{ }^{\prime} ;
$$

E que a variância da diferença entre duas médias quaisquer é:

$$
\hat{\operatorname{Var}}\left(\bar{x}_{i j}-\bar{x}_{i j}\right)=2 \hat{\sigma}_{e}^{2}
$$

\subsection{Estimação das Somas de Quadrados dos Efeitos}

$$
\begin{aligned}
& S Q(\hat{m})=\hat{m} Y_{. .}=\frac{2}{n(n+1)} Y_{.}^{2} ; \\
& S Q\left(\hat{g}_{i}\right)=S Q(C G C)=\sum_{i} \hat{g}_{i}\left(Y_{i i}+Y_{i .}\right)=\frac{1}{p+2}\left[\sum_{i}\left(Y_{i i}+Y_{i .}\right)^{2}-\frac{4}{n} Y_{. \cdot}^{2}\right] ; \\
& S Q(C E C)=\sum_{i} \sum_{\leq j} Y_{i j}^{2}-\frac{1}{p+2} \sum_{i}\left(Y_{i i}+Y_{i .}\right)^{2}+\frac{2}{(p+1)(p+2)} Y_{. \cdot}^{2} ;
\end{aligned}
$$




$$
\mathrm{QM}_{\mathrm{e}^{\prime}}=\frac{\mathrm{QM}}{\mathrm{r}}, \mathrm{QM} \mathrm{e} \text { é o quadrado médio do resíduo da anava individual (Tabela 3.2) e } \mathrm{r}
$$

é o número de repetições. $O$ esquema da análise de variância, com os quadrados médios e suas respectivas esperanças matemáticas, é apresentado na Tabela 4.2 .

$\dot{E}$ importante ressaltar que em $F_{2}$ a contribuição dos efeitos de dominância para a média e para a variância ficam respectivamente reduzida a $1 / 2$ e a $1 / 4$ em relação à geração $F_{1}$. Isso ocorre porque, em média, $50 \%$ dos locos que estavam em heterozigose em $\mathrm{F}_{1}$ tornam-se homozigóticos em $F_{2}$. Desse modo, a CEC, em $F_{2}$, não é estimada em toda sua plenitude, uma vez que depende principalmente dos efeitos de dominância. No entanto, essa perda pode ser compensada pelo uso de um maior número de plantas $F_{2}$. Por outro lado, a CGC depende muito mais, dos efeitos aditivos. Esse aspecto é bastante interessante, pois a soja bem como outras autógamas, tem problemas de obtenção de grandes quantidades de sementes $F_{1}$ e 0 maior interesse aplicado reside na CGC, uma vez que o material final (cultivares) são linhagens homozigóticas.

\subsubsection{Análises dialélica em vários ambientes (Singh, 1973 a,b; 1979)}

Considerando importante a prática de conduzir o mesmo experimento em vários ambientes, realizou-se também a análise conjunta do dialelo, ensaiados em dois locais (ESALQ e Estação Experimental Anhembi). 0 modelo da análise conjunta é como segue:

$$
Y_{i j k}=u+g_{j}+g_{j}+s_{i j}+I_{k}+\lg _{i k}+\lg _{j k}+\operatorname{ls}_{i j k}+\bar{\varepsilon}_{i j k} \quad \text {, em que }
$$

u: média geral do dialelo considerando todos os ambientes ;

gi: efeito da capacidade geral de combinação (CGC) do parental i ;

$g_{j}$ : efeito da capacidade geral de combinação (CGC) do parental j ;

$S_{i j:}$ efeitos da capacidade especíica de combinação (CEC) para o cruzamento entre os parentais i e j. Para o caso dos parentais, tem-se que $s_{i j}=s_{i i}=s_{i j}$;

$\mathrm{I}_{\mathrm{k}}$ : efeito de ambiente $\mathrm{k}$; 
$\lg _{\mathrm{ik}}$ : efeito da interação da CGC do parental i com o ambiente $\mathrm{k}$;

$\lg _{\mathrm{jk}}$ : efeito da interação da CGC do parental $\mathrm{j}$ com 0 ambiente $\mathrm{k}$;

$\mid \mathrm{I}_{\text {ijk }}$ : efeito da interação da CEC para o cruzamento entre os parentais i e j com o ambiente k. Para o caso dos parentais, $\mathrm{sij}_{\mathrm{ij}}=\mathrm{s}_{\mathrm{ii}}=\mathrm{s}_{\mathrm{ii}}$;

$e_{i j k}$ erro médio associado a $Y_{i j k}$.

$i, j=1,2,3, \ldots, n$;

$k=1,2,3, \ldots, 1$;

Para que esse modelo seja válido são impostas as seguintes restrições:

eijk: deve ter distribuição normal e ser independentemente distribuido NID $\left(0, \sigma_{\mathrm{e}}^{2}\right)$, isto é, $E\left(e_{i j k}\right)=0$ e $E\left(e_{i j k}{ }^{2}\right)=\sigma_{e}^{2}$;

Para que os efeitos incluídos no modelo sejam estimáveis, faz-se necessária a imposição de restrições nas soluções. No presente caso, adotou-se:

$$
\begin{aligned}
& \sum_{i=1}^{n} \hat{g}_{i(j)}=0 ; \\
& \sum_{j} \hat{s}_{i j}+\hat{s}_{i i}=0 \text { para cada } i ; \\
& \sum_{k} \hat{l}_{k}=0 ; \\
& \left.\sum_{k}\right|_{\hat{g}_{i k}}=0 ; \\
& \sum_{k} \mid \hat{g}_{j k}=0 ; \\
& \sum_{k}\left|\hat{s}_{i j k}+\right| \hat{s}_{i i k}=0 ;
\end{aligned}
$$

\subsection{Estimação de Parâmetros}

Os efeitos da média, CGC e CEC foram estimados através das seguintes fórmulas, respectivamente: 


$$
\begin{aligned}
& \hat{u}=\frac{2}{n(n+1) !} Y \ldots \\
& \hat{g}=\frac{1}{1(n+2)}\left(Y_{i . .}+Y_{i i .}-\frac{2}{n} Y_{. . .}\right) \\
& \hat{s}_{i j}=\frac{Y_{i j .}}{l}-\frac{1}{l(n+2)}\left(Y_{i . .}+Y_{i i}+Y_{j . .}+Y_{i j .}\right)+\frac{2}{1(n+1)(n+2)} Y_{\ldots} \\
& \hat{\imath}_{k}=\frac{2 Y_{. k}}{n(n+1) \quad 2 Y_{\ldots}} n \\
& \lg _{i k}=\frac{1}{n+2}\left[Y_{i . k}+Y_{i i k}-\frac{2 Y_{. . k}}{n}\right]-\frac{1}{1(n+2)}\left[Y_{i . .}+Y_{i i .}-\frac{2 Y_{\ldots} . .}{n}\right]
\end{aligned}
$$

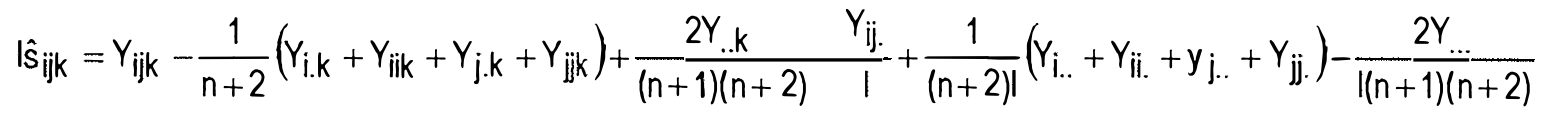

As variâncias do efeito da média e dos efeitos e das diferenças entre os efeitos da CGC e da CEC foram estimados pelas seguintes fórmulas:

$$
\begin{aligned}
& \hat{\operatorname{Var}}(\hat{\mu})=\frac{2}{n !(n+1)} \hat{\sigma}_{e}^{2} \\
& \hat{\operatorname{Var}}\left(\hat{g}_{i}\right)=\frac{n-1}{n !(n+2)} \hat{\sigma}_{e}^{2} \\
& \hat{\operatorname{Var}}\left(\hat{\mathbf{s}}_{i i}\right)=\frac{n(n-1)}{1(n+1)(n+2)} \hat{\sigma}_{\mathrm{e}}^{2} \\
& \hat{\operatorname{Var}}\left(\hat{\mathbf{s}}_{i j}\right)=\frac{n^{2}+n+2}{1(n+1)(n+2)} \hat{\sigma}_{e}^{2}, \text { para } i \neq j \\
& \hat{\operatorname{Var}}\left(\hat{g}_{i}-\hat{g}_{j}\right)=\frac{2}{1(n+2)} \hat{\sigma}_{e}^{2}, \text { para } i \neq j \\
& \hat{\operatorname{Var}}\left(\hat{s}_{i i}-\hat{s}_{j j}\right)=\frac{2(n-2)}{l(n+2)} \hat{\sigma}_{e}^{2} \text {, para } i \neq j \\
& \hat{\operatorname{Var}}\left(\hat{\mathrm{s}}_{\mathrm{ij}}-\hat{\mathrm{s}}_{\mathrm{ik}}\right)=\frac{2(\mathrm{n}+1)}{\mathrm{I}(\mathrm{n}+2)} \hat{\sigma}_{\mathrm{e}}^{2}
\end{aligned}
$$




$$
\begin{aligned}
& \hat{\operatorname{Var}}\left(\hat{\mathrm{s}}_{\mathrm{y}}-\hat{\mathrm{s}}_{\mathrm{km}}\right)=\frac{2 \mathrm{n}}{\mathrm{I}(\mathrm{n}+2)} \hat{\sigma}_{\mathrm{e}}^{2} \\
& \hat{\operatorname{Var}}(\mid \hat{g})_{i k}=\frac{(I-1)(n-1)}{n l(n+2)} \hat{\sigma}_{\mathrm{e}}^{2} \\
& \hat{\operatorname{Var}}(I \mathrm{~S})_{\text {iik }}=\frac{\mathrm{n}(\mathrm{n}-1)(1-1)}{I(n+1)(n+2)} \hat{\sigma}_{\mathrm{e}}^{2}
\end{aligned}
$$

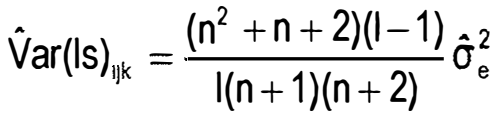

$$
\begin{aligned}
& \hat{\operatorname{Var}}\left[(\mid g)_{i k}-(\mid g)_{j k}\right]=\frac{2(l-1)}{n(n+2) \mid} \hat{\sigma}_{e}^{2} \\
& \hat{\operatorname{Var}}\left[(I S)_{i \mathrm{ik}}-(\mid \mathrm{I})_{\mathrm{ik}}\right]=\frac{2(n+1)(\mid-1)}{(n+2) \mid} \hat{\sigma}_{\mathrm{e}}^{2} \\
& \hat{\operatorname{Var}}\left(I_{k}\right)=\frac{2(I-1)}{\ln (n+1)} \hat{\sigma}_{e}^{2}
\end{aligned}
$$

Além dessas variâncias para a média de qualquer parental ou cruzamento $F_{2}$, tem-se

que:

$$
\hat{\operatorname{Var}}\left(\mathrm{x}_{\mathrm{ij}}\right)=\hat{\sigma}_{\mathrm{e}}^{2}=\mathrm{QM}_{\mathrm{e}^{\prime}} \text {; }
$$

E que a variância da diferença entre duas médias quaisquer é:

$$
\hat{\operatorname{Var}}\left(\overline{\mathrm{x}}_{\mathrm{ij}}-\overline{\mathrm{x}}_{\mathrm{ij}}\right)=2 \hat{\sigma}_{\mathrm{e}}^{2}
$$

\subsection{Estimação das Somas de Quadrados dos Efeitos}

$$
\begin{aligned}
& S Q(\hat{m})=\frac{2}{n(n+1) !} Y_{\ldots}^{2}
\end{aligned}
$$

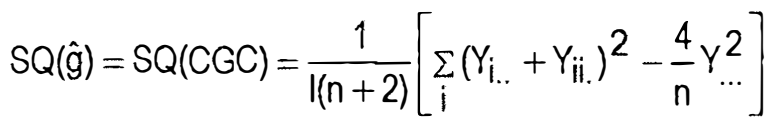

$$
\begin{aligned}
& S Q(\hat{s})=S Q(C E C)=\frac{\sum_{i \leq j} Y_{i j .}^{2} \quad \sum_{i}\left(Y_{i . .}+Y_{i i .}\right)^{2}}{1}+\frac{2 Y_{\ldots .}^{2}}{1(n+2)}+\frac{1(n+1)(n+2)}{1}
\end{aligned}
$$




$$
\begin{aligned}
& S Q\left(\hat{l}_{k}\right)=\begin{array}{cc}
2 \sum Y_{k}^{2} \cdot . k & 2 Y^{2} \\
\hline n(n+1) & n(n+1) !
\end{array} \\
& S Q(\mid \hat{g})=\frac{\sum_{i k}\left(Y_{i . k}+Y_{i i k}\right)^{2}}{n+2}-\frac{k \sum_{. . k} Y^{2}}{n(n+2)}-\frac{\sum_{i}\left(Y_{i . .}+Y_{i i .}\right)^{2}}{(n+2) !}+\frac{4 Y_{\ldots . .}^{2}}{n(n+2) !} \\
& S Q(\hat{\mathbf{s}})=\sum_{k} \sum_{i \leq j} Y_{i j k}^{2}-\frac{\sum_{k i} \sum_{i}\left(Y_{i . k}+Y_{i j k}\right)^{2}}{n+2}+\frac{2 \sum_{k} Y_{. . k}^{2}}{(n+1)(n+2)}-\frac{\sum_{i \leq j} \sum_{i j .}^{2}}{I}+\frac{\sum_{i}\left(Y_{i . .}+Y_{i i}\right)^{2}}{(n+2) I}-\frac{2 Y_{\ldots .}^{2}}{(n+1)(n+2) I}
\end{aligned}
$$

O esquema da análise de variância, com os quadrados médios e suas respectivas esperanças matemáticas, é apresentado na Tabela 4.3.

\subsection{RESULTADOSE DISCUSSÃO}

\subsubsection{Análises dialélicas}

Após a realização das análises de variância individual e conjunta apresentadas nas Tabelas 3.5, 3.6 e 3.7, constatou-se diferenças significativas tanto para efeitos de Tratamentos (T), seus desdobramentos e interações para a maioria dos caracteres avaliados. Procedeu-se, então, a análise individual da capacidade de combinação, desdobrando-se a soma de quadrados de tratamentos em soma de quadrados da capacidade geral de combinação (CGC) e capacidade específica de combinação (CEC), de acordo com o método 2, modelo misto B de Griffing (1956a). Realizou-se também a análise dialélica conjunta, com a interação TXL e seu desdobramento em CGC x L e CEC x L.

Os resultados das análises individuais e conjunta para a capacidade de combinação são apresentados nas Tabelas 4.4 e 4.5. As CGC e CEC foram significativas $(p<0,01)$ para todos os caracteres tanto nas análises individuais quanto na conjunta. A única exceção foi para CEC no caráter \%OL em Anhembi. A CGC decorre principalmente da variância genética aditiva e da variância epistática aditiva $x$ aditiva e a CEC resulta da variância genética dominante e de vários tipos de componentes da variância epistática envolvendo dominância, podendo-se concluir que 
para a expressão da maioria dos caracteres, as ações gênicas aditiva, dominante e provavelmente epistáticas foram importantes. Segundo Assmann (1999), embora a magnitude dos quadrados médios não indique a importância relativa dos componentes de variação genética, os valores de F, significativos para CGC e CEC, mostram a existência de variabilidade devido à ação aditiva e não-aditiva dos genes, respectivamente. Presença de significância para os efeitos da CEC foram obtidos por diversos autores em estudos dialélicos com soja (Bhatade et al., 1977; Pimentel, 1991; Sharma et al., 1993; Sharma \& Phul, 1994; Pulcinelli, 1997; Gadag et al., 1999). Soldini (1998) também não encontrou diferenças significativas para CEC para o caráter \%OL num dialelo parcial em soja, já Liu (1988) relatou a importância da ação gênica aditiva para \%OL na geração $\mathrm{F}_{2}$ em soja, concordando com os resultados encontrados neste trabalho apenas para um dos locais.

A relação entre CGC e CEC foi avaliada por Baker (1978) para o modelo com efeitos de tratamentos fixos (Tabela 4.4). Na presente pesquisa, em cinco caracteres, a relação

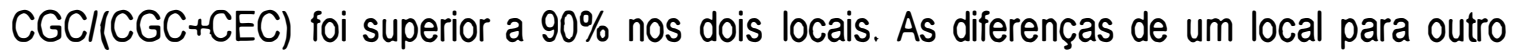
ocorreram para \%OL com $68 \%$ na ESALQ e $91 \%$ em Anhembi ; já para os caracteres PG e PO, o local ESALQ apresentou maiores relações que em Anhembi, sendo de 95\% (PG) e 94\% (PO) na ESALQ e 85\% (PG) e 80\% (PO) em Anhembi. No geral, detectou-se uma predominância de efeitos da CGC em relação a CEC no controle desses caracteres para esse grupo de parentais. Predominância da CGC em relação à CEC também foi encontrada por vários autores para inúmeros caracteres em soja (Freire Filho, 1988; Nass, 1989; Pimentel, 1991; Sharma et al., 1993; Soldini, 1998; Gadag et al., 1999; Spehar, 1999). No entanto, Sharma \& Phul. (1994) mostraram que ação gênica não-aditiva foi mais importante na relação CGC/CEC em vários caracteres, destacando-se PG e \%OL. Pelos resultados conseguidos neste estudo e pelos observados na literatura, ficou evidente uma tendência da CGC ser superior a CEC, para caracteres como aqueles relacionados ao florescimento, maturidade, produtividade e seus componentes.

A média das estimativas da variância dos efeitos da CGC foi maior do que para a CEC para sete dos oito caracteres pesquisados na ESALQ e em seis em Anhembi (Tabela 4.4). Destes, somente os caracteres NDF, APF, NDM, APM e VA tiveram comportamento semelhante 
nos dois locais. Já para os caracteres, PG, \%OL e PO o comportamento foi modificado conforme o local; a média das estimativas da variância dos efeitos da CEC foi maior que a CGC para \%OL na ESALQ, enquanto que em Anhembi esse comportamento foi verificado para os caracteres PG e PO. Portanto, ocorreu uma resposta diferenciada dos efeitos de CGC e CEC frente aos diferentes ambientes.

A análise conjunta do dialelo mostrou efeitos altamente significativos para locais (L), CGC, CEC, CGCXL e CECXL (Tabela 4.5). Os efeitos das interações CEC X L não apresentaram significância apenas para os caracteres NDM e \%OL; isso sugere que a CEC foi mais estável que a CGC para esses caracteres. De forma geral, as interações envolvendo CGC e CEC indicam que os efeitos das capacidades geral e especifica devem ser melhor estimados a partir da análise conjunta e ainda sugere a necessidade de se selecionar tanto parentais quanto cruzamentos em ambientes especificos e ou também identificar aqueles que não apresentam variações muito altas através dos locais. Resultados envolvendo interações entre as capacidades de combinação geral e específica com anos em soja foram relatados por Paschal \& Wilcox (1975), Kunta et al. (1985) e Pulcinelli (1997). Os dois primeiros trabalhos ressaltam que embora as interações tenham sido significativas, elas foram de pequena magnitude, podendo ser desprezada. No entanto, Pulcinelli (1997) observou interações altamente significativas tanto em $F_{2}$ quanto $F_{2: n}$, destacando que embora a magnitude das interações tenha sido inferior em relação aos demais efeitos, estas apresentaram quadrados médios significativos, não podendo ser desprezadas. Tais interações devem causar desvios na classificação dos parentais com base nos parâmetros do modelo da análise dialélica. Essas conclusões reforçam o que foi observado neste trabalho, envolvendo interações com locais, mostrando que CGC, CEC e suas interações foram importantes para este grupo de parentais. Consequentemente, deve-se considerar tanto 0 desempenho médio de um parental no cruzamento, quanto as combinações hibridas especificas, buscando-se selecionar ambas, linhagens parentais e combinações hibridas, especificas para cada ambiente. 


\subsubsection{Capacidade geral de combinação}

As estimativas dos efeitos da capacidade geral de combinação $\left(g_{i}\right)$ individual e conjunta, sua interação com locais $\left(\lg _{i k}\right)$ e desvios padrões são apresentados na Tabela 4.6.

Desde que $\sum g_{i}=0$, quando a estimativa de $g_{i}$ do parental $i$ tem baixo valor absoluto a sua CGC está em torno da média da CGC de todos os parentais. Por outro lado, estimativas de $g_{i}$ de alto valor absoluto indicam que o parental $i$ tem CGC superior ( $g_{i}$ positivo) ou inferior ( $g_{i}$ negativo) aos parentais com os quais estão sendo comparados (Freire Filho, 1988).

Em geral, a ordem dos parentais baseada na média (Tabelas 3.8 e 3.9, capítulo 3) foram semelhantes à ordem baseada nas estimativas dos efeitos da CGC para todas as caracteristicas. Ou seja, o desenvolvimento per se dos parentais foi indicativo de seus efeitos gi's, de modo que quando essa associação é verdadeira, torna-se mais fácil fazer a seleção correta dos parentais. Associações positivas entre médias e gis foram relatadas por Srivastava et al. (1978), Kaw \& Menon (1980) e Gadag et al. (1999).

Para o caráter NDF, os valores de $g_{i}$, tanto por local quanto conjunta, foram negativos para os mesmos quatro parentais (Hartwig, USP 1-11, USP 2-16 e USP 5-19), destacando-se Hartwig com uma contribuição para redução superior a cinco dias para o inicio do florescimento. No outro extremo estão os parentais Conquista e MTBR 123.800 com gi's de 3,8146 e 4,5646 dias respectivamente nos dois locais, o que representa uma contribuição média de quatro a cinco dias para atrasar o florescimento. Praticamente, os mesmos parentais que apresentam gis positivos para NDF apresentaram também para APF, com exceção do parental USP 1-11 que teve $g_{i}$ positivo para APF na ESALQ e na conjunta. Pode-se destacar o parental Conquista com valor de $g_{i}=8,3458 \mathrm{~cm}$ (ESALQ), o qual mostrou maior potencial para aumentar a APF.

No caráter NDM, quatro parentais apresentaram estimativas de $g_{i}$ negativas tanto nas análises individuais quanto na conjunta. Os parentais Hartwig e USP 5-19 na ESALQ e USP 2-16 em Anhembi, contribuiram com as maiores reduções para esse caráter. Isso indica que tais parentais têm potencial para redução do ciclo total em até sete dias. No outro extremo estão os parentais Conquista e MTBR 123.800, com gi's de 5,8417 e 10,2667 dias, ambos na ESALQ, contribuindo geneticamente para atrasar o NDM em 5 a 10 dias o ciclo total. 
O parental que mais contribuiu para aumentar a APM foi USP 1-11; já o parental Hartwig contribuiu com a maior redução na altura, ambos na ESALQ. Os parentais USP 1-11, USP 2-16 e USP 5-19 tiveram um comportamento interessante, pois apresentaram ao mesmo tempo gi's negativo para maturidade (precocidade) e g's positivos para APM, independentemente do local. Nesses parentais, em termos de CGC, esses dois caracteres tiveram comportamentos relativamente independentes, significando que ao mesmo tempo em que eles contribuiram para reduzir o ciclo, contribuíram também para aumentar a altura da planta na maturação.

$O$ caráter VA é bastante complexo, principalmente pelo fato de envolver uma avaliação visual que leva em consideração vários caracteres ao mesmo tempo, de modo que os gis apresentaram estimativas diferentes conforme o local avaliado. Na ESALQ, cinco dos seis parentais apresentaram estimativas de g's positivas e superiores ao desvio padrão; apenas 0 parental Hartwig apresentou gi negativo $(-0,1917)$, podendo ser explicado pela reduzida estatura e pelo número de vagens consequentemente menor. Já em Anhembi, somente os parentais Conquista e USP 1-11 apresentaram g's positivos. Pode-se observar que o parental Hartwig apresentou valor negativo e elevado de $g_{i}$ independentemente do local avaliado; esse fato deve estar associado aos caracteres APF, APM e PG que também apresentaram gis negativos. 0 mesmo comportamento foi observado para os parentais Conquista e USP 1-11, porém com sinal positivo para $g_{i}$; os demais parentais mostraram modificações de valores e sinais de g's conforme o local avaliado. Isso pode ser explicado pelo fato do VA ser um caráter subjetivo, portanto, bastante influenciado pelas condições ambientais e experimentais.

Para PG, apenas o parental Conquista apresentou estimativas de $g_{i}$ altas e positivas nos dois locais. Os parentais USP 1-11, USP 2-16 destacaram-se apenas na ESALQ. 0 único parental que apresentou valor e sinal de gi modificado pelo ambiente foi MTBR 123.800 que se destacou pela maior estimativa de $g_{i}$ em Anhembi, não sendo superado por nenhum dos parentais estudados.

O caráter \%OL apresentou estimativas de gis positivas independentemente do local avaliado. Os parentais com g's positivos foram USP 1-11, USP 2-16 e USP 5-19 com estimativas bem superiores ao desvio padrão. 0 parental Hartwig apresentou estimativa de gi positiva em Anhembi e na conjunta (ESALQ e Anhembi). Para o caráter PO, as estimativas de gís foram 
positivas para os parentais Conquista, USP 1-11 e USP 2-16, independentemente do local avaliado; por outro lado, os parentais Hartwig e USP 5-19 mostraram gis negativas. De acordo com o observado, o caráter PO é determinado muito mais pelo caráter $\mathrm{PG}$ que pelo $\% \mathrm{OL}$, no que diz respeito aos sinais de g's, pois sempre PO acompanha a tendência de PG.

$O$ efeito de locais $\left(l_{k}\right)$ foi positivo na ESALQ para todos os caracteres, com exceção de PG e PO; o inverso ocorreu em Anhembi; portanto a ESALQ mostrou-se um bom local para avaliação de caracteres relacionados ao florescimento e à maturidade, enquanto que Anhembi mostrou-se melhor para avaliar o potencial produtivo, tanto dos parentais quanto de suas combinações hibridas. No que diz respeito às interações dos efeitos dos gis com locais ( $\left(g_{i k}\right)$, pode-se observar que elas foram suficientes para promover inversões na ordem de classificação dos valores de gís. O único parental que interagiu com a ESALQ de forma a diminuir todos os caracteres foi Hartwig, mostrando ser mais precoce e menos produtivo que em Anhembi, fato comprovado pelas médias (Tabela 3.8). No entanto, os parentais restantes apresentaram para NDM Igik's negativos em Anhembi $\left(l_{k}=-4,5548\right)$, mostrando maior precocidade nesse local. Outro fato interessante a ser observado é que o local ESALQ atuou de forma positiva na manifestação das estimativas $g_{i k}$ 's para o caráter PG; no entanto, 0 efeito da estimativa de $l_{k}$ agiu em sentido contrário. Embora as interações para o caráter PG tenham sido positivas em sua maioria, o efeito do ambiente $\left(l_{k}=-4,6095\right)$ foi forte 0 suficiente para ocasionar uma pequena redução na média geral.

A partir do exposto, com respeito ao comportamento dos parentais em termos de efeitos da CGC e de suas interações, constata-se que para todos os caracteres esse grupo de parentais mostrou uma ampla variação de $g_{i}$. Nenhum dos parentais apresentou $g_{i}$ satisfatório para todos os caracteres. Deve-se ressaltar que o parental Hartwig teve um comportamento fraco para todos os caracteres, talvez pelo fato de ser um genótipo introduzido e não ser adaptado às condições ambientais brasileiras, sendo usado principalmente como fonte de genes para resistência ao nematóide de cisto da soja (Heterodera glycines, Ichinohe), peste importante na cultura da soja. Já os parentais USP 1-11 e USP 2-16 destacaram-se por apresentarem comportamento relativamente independente para vários caracteres, significando que ao mesmo tempo em que eles contribuiram para reduzir um caráter contribuiram também para aumentar 
outro, como foi o caso por exemplo da redução do ciclo e aumento da produtividade. Desse modo, evidencia-se que esses parentais apresentam características complementares em decorrência da variabilidade existente entre eles. No entanto outro fator que deve ser considerado é a interação $\lg _{i k}$, pois ele pode causar uma mudança na ordem da classificação dos parentais, como mostrado, levando a conclusões errôneas em termos da seleção dos melhores.

Para PG, o caráter de maior importância econômica, o parental Conquista foi o que apresentou melhor CGC; já os parentais USP 1-11 e USP 2-16 tiveram boa capacidade de combinação para produtividade bem como para outras características.

\subsubsection{Capacidade específica de combinação}

As estimativas dos efeitos das capacidades especificas de combinação e suas interações referentes aos parentais e seus cruzamentos, estão relacionadas nas Tabelas 4.7,4.8 e 4.9. A interpretação do efeito da capacidade especifica de combinação, compreende 0 desvio de um hibrido em relação ao que seria esperado com base na CGC de seus parentais. Desse modo, baixo valor de $s_{\mathrm{ij}}$ indica que o hibrido comporta-se conforme o esperado a partir da CGC de seus parentais, ou seja, há predominância dos efeitos aditivos e, possivelmente, epistáticos aditivo $\mathrm{x}$ aditivo. Por outro lado, alto valor absoluto de $s_{\mathrm{ij}}$ indica que $\mathrm{o}$ cruzamento em questão é superior ( $s_{i j}$ positivo) ou inferior ( $s_{i j}$ negativo) ao esperado com base na CGC dos respectivos parentais. As estimativas da CEC estão, portanto, relacionadas com genes que exibem efeitos de dominância ou epistasia (Griffing, 1956b).

A manifestação dos efeitos gênicos de um individuo é o resultado da contribuição trazida pelos parentais e de um efeito oriundo da interação dos dois gametas especificos que originaram aquele individuo. A contribuição gamética constituida dos efeitos aditivos dos alelos $e$ da parte da interação aditivo x aditivo é independente do genótipo (Assmann, 1999).

O método 2 de Griffing (1956a) inclui os hibridos e os seus parentais, neste método $\mathrm{sii}_{\mathrm{ii}}$ corresponde a CEC do parental i com ele próprio e os efeitos de $s_{i j}$ correspondem a CEC dos parentais i e j. Segundo Cruz \& Regazzi (1994), os valores de sii têm grande significado genético, 
tanto no seu sinal quanto na sua magnitude. $O$ sinal negativo dos Sii desvios da dominância unidirecionais e, consequentemente, a manifestação de heterose positiva nas combinações hibridas de parentais divergentes. A magnitude de $s_{i i}$ é um indicativo da divergência genética do parental i em relação ao conjunto dos outros parentais considerados no dialelo; quanto maior for o valor absoluto de $s_{\mathrm{ii}}$, maior será o efeito da heterose varietal, ou inerente ao cultivar, que é manifestada em todos os seus híbridos. Dessa forma, conclui-se que todo $s_{i i}$ é de fundamental importância para indicar a direção dos desvios de dominância. Este parâmetro será negativo quando os desvios forem predominantemente positivos e será negativo em caso contrário. Logo, quanto menor for 0 efeito de $\mathrm{s}_{\mathrm{ii}}$, em valor absoluto, mais próximo estará a freqüência gênica do parental i da freqüência média dos parentais, e consequentemente, menor divergência ele terá em relação aos demais (Cruz \& Vencovsky, 1989).

Em soja, diversos autores têm empregado o método 2 (Griffing, 1956a) para análise de cruzamentos dialélicos (Bhatade et al., 1977; Toledo \& Kiihl, 1982; Freire Filho, 1988; Nass, 1989; Pimentel, 1991; Sharma \& Phul, 1994; Gadag et al., 1999). No entanto, os efeitos de sii não foram bem discutidos.

Nesse estudo, as estimativas de $s_{i i}$ nos diferentes locais (Tabela 4.7), apresentaram grande variação para a maioria dos caracteres, exceto para VA e \%OL. Constata-se que há uma considerável divergência entre os parentais e que nenhum deles apresentou os maiores ou menores valores absolutos de $s_{i i}$ para todos os caracteres. Isso sugere que os extremos de divergência podem ser provenientes de diferentes parentais nos diferentes caracteres. Desse modo pode-se observar que os parentais Hartwig e MTBR 123.800 apresentaram os valores mais extremos para a maioria dos caracteres, destacando-se NDM, APM e PG; tal fato sugere que a diversidade geográfica pode ser um indicativo da diversidade genética, visto que Hartwig é um genótipo introduzido e MTBR 123.800 é adaptado à região Centro-Oeste, possuindo genes para tolerância ao fotoperiodo.

A proporção de valores sii positivos e negativos variou com o caráter estudado, sendo mais positiva para NDF, APF, NDM, VA, e, mais negativa para os caracteres APM, PG, \%OL e PO. Nestes quatro caracteres a heterose média foi positiva (dados referentes a tese, nãopublicados), concordando com as afirmações de Cruz \& Vencovsky (1989). 
As estimativas da interação do efeito da capacidade especifica de combinação por locais para parentais $\left(I_{\mathrm{sik}}\right)$ podem ser observadas na Tabela 4.7. Nesta tabela, o efeito de $I_{\text {iik }}$ foi mais pronunciado que para $\lg _{\mathrm{ik}}$ principalmente para os caracteres APF, APM e PG, talvez pelo fato de que estas caracteristicas diferenciavam bastante os genótipos e, também, por serem muito influenciadas pelas condições ambientais.

Nas Tabelas 4.8 e 4.9 são apresentados os resultados dos efeitos $\mathrm{s}_{\mathrm{ij}}$ e suas interações (Isijk). Para NDF, visando precocidade, os cruzamentos que apresentaram melhores valores para $S_{i j}$ nos dois locais foram: Conquista x MTBR 123.800 ( $\left.2 \times 5\right)$, USP 1-11 x MTBR $123.800(3 \times 5)$, USP 2-16 x MTBR 123.800 ( $4 \times 5$ ) e MTBR 123.800 x USP 5-19 (5 × 6). Os cruzamentos Hartwig x MTBR 123.800 ( 1 × 5) e Hartwig x USP 2-16 ( 1 × 4) destacaram-se na ESALQ e em Anhembi, respectivamente. Os hibridos mais precoces tiveram pelo menos um parental com gi negativo, podendo-se ainda dizer que o parental MTBR 123.800 (5) mostrou uma boa capacidade de combinação para este caráter, pela sua repetibilidade nos vários cruzamentos, embora com $\mathrm{g}_{\mathrm{i}}$ positivo.

Para APF, somente os cruzamentos Hartwig $\times$ USP 1-11 $(1 \times 3)$ e Conquista $\times$ USP 1 $11(2 \times 3)$ se destacaram com as maiores estimativas de $s_{\mathrm{ij}}$ para os dois locais. Já o cruzamento Hartwig $\times$ USP 2-16 $(1 \times 4)$ se destacou apenas na ESALQ, enquanto que os cruzamentos Conquista x USP 5-19 ( $2 \times 6)$, USP 1-11 x USP 2-16 ( $3 \times 4)$ e USP 2-16 x MTBR $123.800(4 \times 5)$ em Anhembi. Observa-se que todos os seis parentais estão envolvidos nestes cruzamentos e que o parental Conquista (2) apresentou a segunda maior estimativa de $g_{i} e$ apareceu em dois dos seis cruzamentos.

Com relação ao NDM, a maioria das estimativas de sij foi negativa, demonstrando uma tendência de dominância para precocidade, fato este já verificado por Freire Filho (1988); Nass (1989) e Pimentel (1991). Os cruzamentos Hartwig $\times$ Conquista (1 × 2), Hartwig x MTBR 123.800

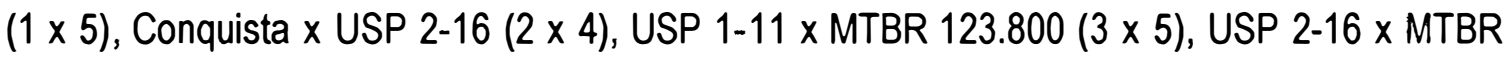
123.800 ( $4 \times 5$ ) e MTBR $123.800 \times$ USP 5-19 ( $5 \times 6)$ apresentaram os menores efeitos da CEC $e$ foram comuns a ambos os locais. A única exceção foi Conquista $\times$ MTBR $123.800(2 \times 5)$ com estimativa de $s_{\text {il }}$ negativa e elevada no local Anhembi. Nesses cruzamentos, pelo menos um 
parental apresentou gi negativo, com exceção do cruzamento USP 1-11 x MTBR $123.800(3 \times 5)$ naESALQ, no qual os dois parentais tiveram gi's positivos.

No caráter APM, houve uma predominância de estimativas de $s_{i j}$ negativas, resultado contrário aos obtidos por Pimentel (1991) e Gadag et al. (1999). As maiores estimativas de $\mathrm{s}_{\mathrm{ij}}$ por local foram obtidas pelos cruzamentos Hartwig x USP 1-11 (1 × 3), Hartwig x USP 5-19 (1 ×6), Conquista x USP 1-11 (2x 3), Conquista x USP 2-16 (2 x 4) e USP 2-16 x MTBR 123.800 (4 x 5). Nesse caráter, também se repetiu o fato de que pelo menos um dos parentais apresentou $g_{i}$ positivo, destacando-se os parentais USP 1-11 (3), USP 2-16 (4) e USP 5-19 (6). Isto indica que estes parentais devem ter locos com alta freqüência de genes dominantes e contrastantes com as freqüências médias das linhagens incluídas no seu conjunto, resultando nos altos valores de $S_{i j}$.

No caráter VA, os cruzamentos que apresentaram as melhores estimativas de $s_{i j}$ foram Hartwig x USP 1-11 (1 × 3), Hartwig x USP 5-19 (1 × 6), Conquista x MTBR $123.800(2 \times 5)$, na ESALQ. Já em Anhembi, os destaques em sij foram Hartwig x USP 1-11 ( $1 \times 3$ ) e USP 2-16 x MTBR 123.800 ( 4 × 5). O cruzamento Hartwig x USP 1-11 (1 × 3) destacou-se como o de maior valor de $s_{i j}$ nos dois locais; o parental USP 1-11 (3) apresentou o melhor $g_{i}$ na ESALQ, sendo 0 segundo em Anhembi.

Na avaliação para PG, o cruzamento Hartwig x USP 1-11 $(1 \times 3)$ apresentou o maior valor para $s_{i j}$ seguido por Conquista $\times$ USP 5-19 $(2 \times 6)$ independentemente do local avaliado. Além desses cruzamentos, destacaram-se também Conquista x MTBR $123.800(2 \times 5)$ e na ESALQ; já em Anhembi, os melhores foram Hartwig x Conquista $(1 \times 2)$, Hartwig x USP 5-19 (1 $x$ 6), Conquista x USP 1-11 (2 x 3), Conquista x USP 2-16 (2 x 4) e USP 2-16 x MTBR 123.800 (4 x 5).

No caráter \%OL novamente o cruzamento Hartwig x USP 1-11 $(1 \times 3)$ apresentou 0 maior valor para $s_{i j}$ independentemente do local, seguido por USP 1-11 x USP 2-16 $(3 \times 4)$. Considerando cada local individualmente, tem-se os seguintes destaques em termos de $s_{i j}$ : Hartwig x MTBR $123.800(1 \times 5)$ e USP 1-11 x USP 5-19 (3 × 6) na ESALQ e os cruzamentos Conquista x USP 2-16 $(2 \times 4)$ e Conquista x USP 5-19 $(2 \times 6)$ em Anhembi. Dentre todos, somente o cruzamento Hartwig x MTBR $123.800(1 \times 5)$ apresentou os dois parentais com $g_{i}$ 
negativos; os demais tiveram pelo menos um parental com gi positivo. Considerando o caráter PO, o cruzamento Hartwig $\times$ USP 1-11 $(1 \times 3)$ apresentou o maior valor para $s_{i j}$ independentemente do local, seguido por Conquista $\times$ USP 5-19 $(2 \times 6)$. Além destes, também mereceram destaque: Hartwig x MTBR 123.800 (1 × 5) na ESALQ e os cruzamentos Hartwig $x$ Conquista (1 $\times 2$ ), Conquista $\times$ USP 1-11 ( $2 \times 3)$, Conquista $\times$ USP 2-16 ( $2 \times 4)$, USP 1-11 $\times$ USP 2-16 ( $3 \times 4$ ) e USP 2-16 x MTBR 123.800 (4 × 5) em Anhembi. Pode-se notar que o caráter PO parece depender mais da PG que do \%OL (Lainez-Mejia, 1996; Rocha, 1998), fato este já observado para gi; a associação entre PO e PG ocorreu principalmente para os cruzamentos Hartwig x USP 1-11 ( 1 × 3) e Conquista x USP 5-19 $(2 \times 6)$ independentemente do local avaliado. Em Anhembi, pode-se destacar o cruzamento USP 2-16 x MTBR 123.800 ( 4 × 5).

Um grande número de cruzamentos apresentou parentais com gis de sinais contrários, cuja combinação resultou num alto efeito de $\mathrm{s}_{\mathrm{ij}}$, como por exemplo o cruzamento Hartwig $\times$ USP 1-11 (1 $\times 3)$. Este fato é importante, pois tais combinações podem gerar segregantes transgressivos, se 0 efeito aditivo de um parental e os efeitos epistáticos complementares do outro parental agirem na mesma direção para a máxima expressão dos caracteres (Sharma \& Phul, 1994).

As estimativas do efeito da interação da CEC com locais (I $\left.s_{\mathrm{jik}}\right)$ encontram-se na Tabela 4.9. Pode-se observar que para os caracteres APF, APM, PG e PO as estimativas de $I_{s i j k}$ foram elevadas; resultado semelhante foi obtido para as estimativas da interação $\lg _{k_{k}}$, com exceção do caráter APF. Geneticamente, os efeitos da CEC por local contém o $s_{i j}$ e Is $s_{i j k}$; quando estas estimativas se aproximam de zero, significa que o efeito médio da CEC aproxima-se do efeito da CEC por local. Isso comprova que o efeito da interação ( $\left(S_{\mathrm{ijk}}\right)$ é bastante importante, podendo alterar o comportamento e, consequentemente, a classificação dos cruzamentos. Mediante esta afirmativa, pode-se ressaltar que 0 efeito da interação não pode ser desprezado como sugerido em outros estudos (Freire Filho, 1988; Pimentel, 1991).

Nessa avaliação da CEC verificou-se que para todos os caracteres nos dois locais, a maioria dos cruzamentos que apresentou os maiores efeitos de $s_{\mathrm{ij}}$, reuniam um parental com efeito da CGC positivo e outro com gi negativo. Isso concorda com os resultados obtidos por Gadag et al. (1999) e Sharma \& Phul (1994). Pode-se também destacar a participação dos 
genótipos Hartwig, Conquista e MTBR 123.800 em vários cruzamentos destaques, demonstrando a importância da divergência genética na manifestação da CEC, como indicado por Freire Filho (1988) e Soldini (1998).

Resumindo as informações sobre as estimativas dos efeitos da CGC $\left(\mathrm{g}_{\mathrm{i}}\right)$, pode-se dizer que todos os parentais se destacaram para mais de uma característica. Para precocidade podemos destacar Hartwig; para PG e PO o destaque ficou para o cultivar Conquista e MTBR 123.800; já as USP's apresentaram comportamento diferenciado. Quanto à CEC podemos enfatizar que algumas combinações hibridas são promissoras para mais de uma característica simultaneamente, podendo ser utilizadas para obtenção de linhagens transgressivas de importância econômica, como exemplo podemos citar as combinações:

Conquista $\times$ USP 2-16 $(2 \times 4)$ para precocidade, altura de planta na maturação, produtividade de grãos e teor de óleo;

Hartwig x USP 1-11 (1 x 3) para altura de planta na maturação, produtividade e teor de óleo;

USP 2-16 x MTBR $123.800(4 \times 5)$ para precocidade, altura de planta na maturação, produtividade de grãos e teor de óleo; Hartwig x MTBR 123.800 ( 1 × 5) para precocidade e teor de óleo; Hartwig $\times$ Conquista $(1 \times 2)$ para precocidade e produtividade de grãos; Conquista $\times$ USP 5-19 $(2 \times 6)$ para produtividade de grãos e teor de óleo; Hartwig $\times$ USP 5-19 $(1 \times 6)$ e Conquista $\times$ USP 1-11 $(2 \times 3)$ para altura da planta na maturidade e produtividade de grãos. 

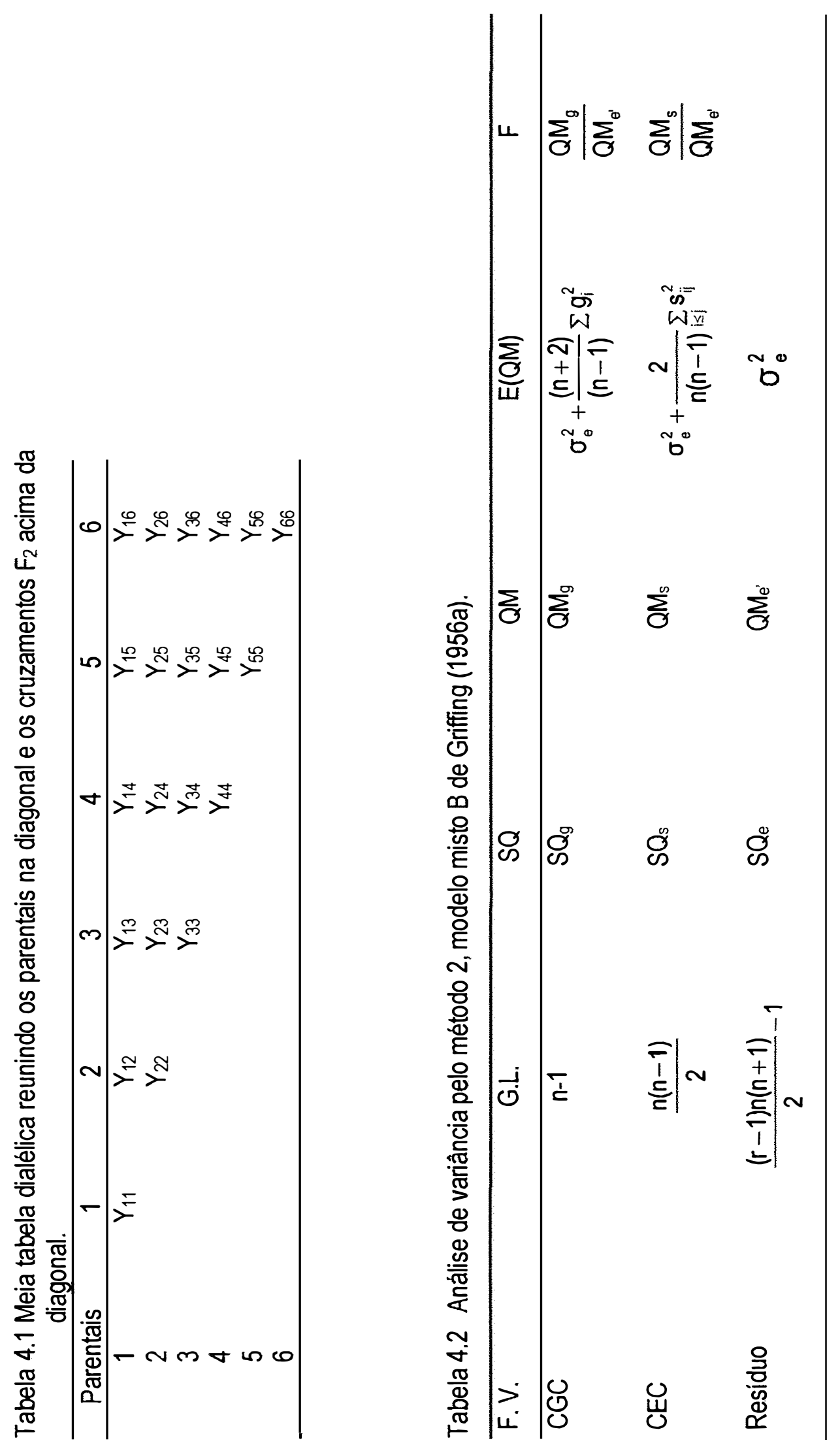


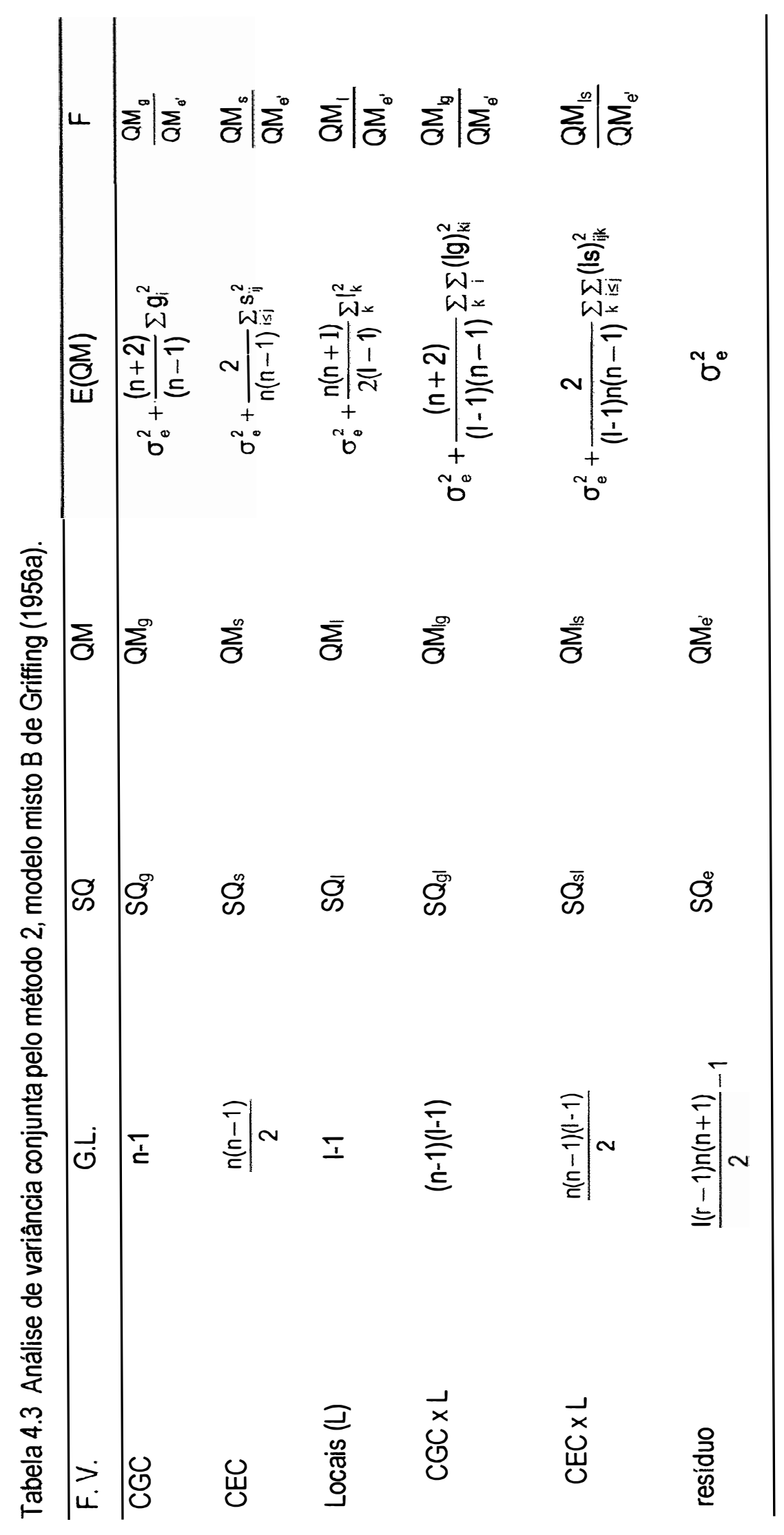




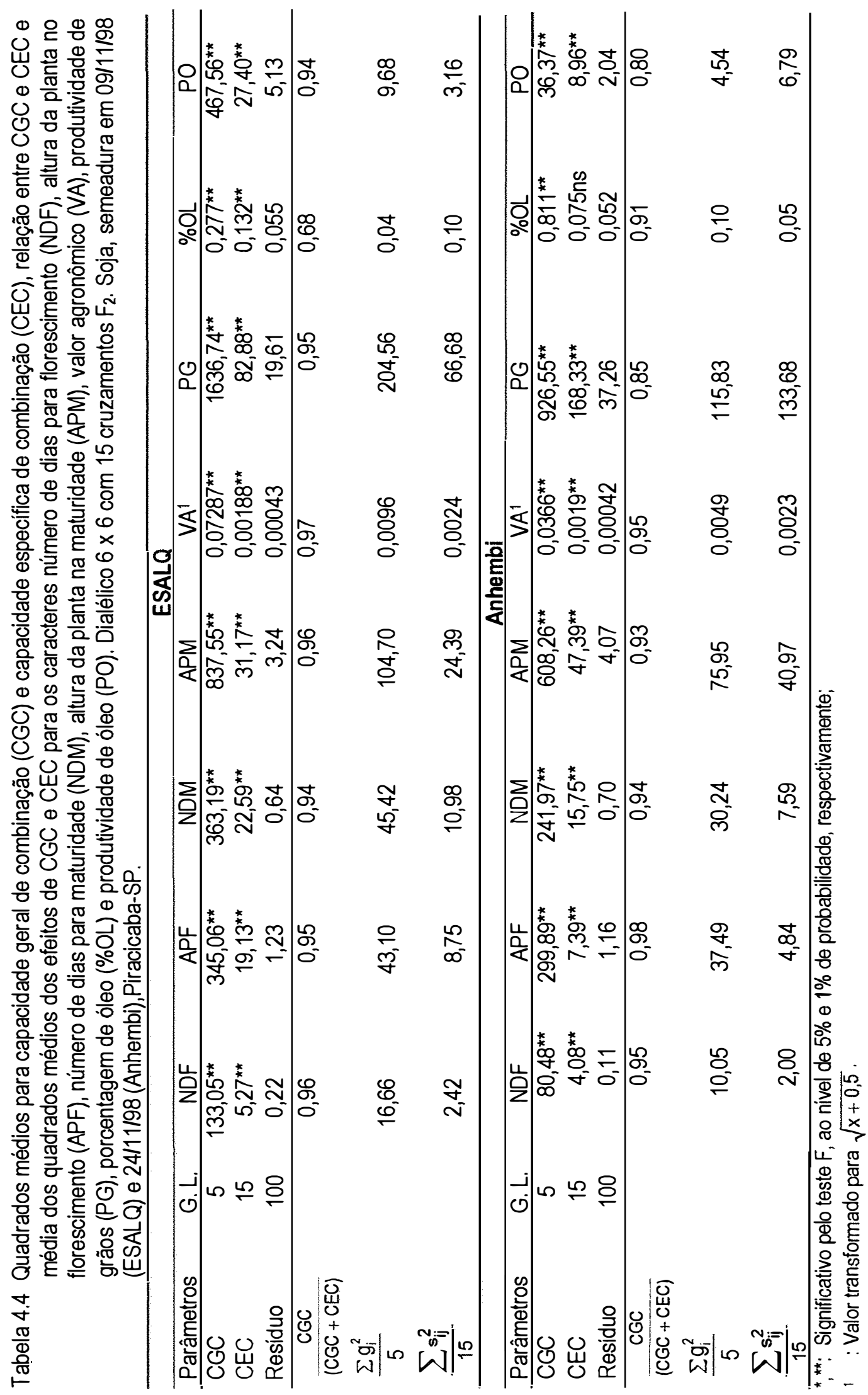




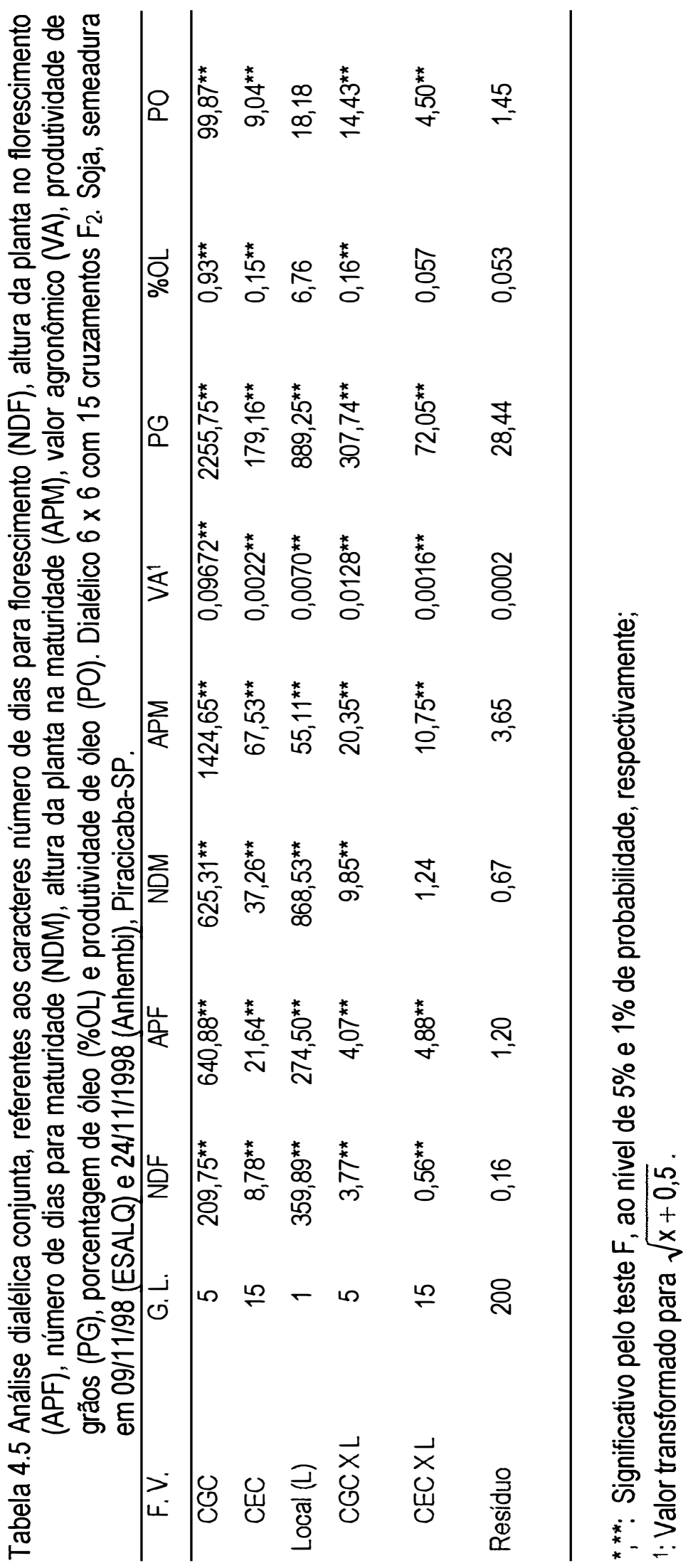




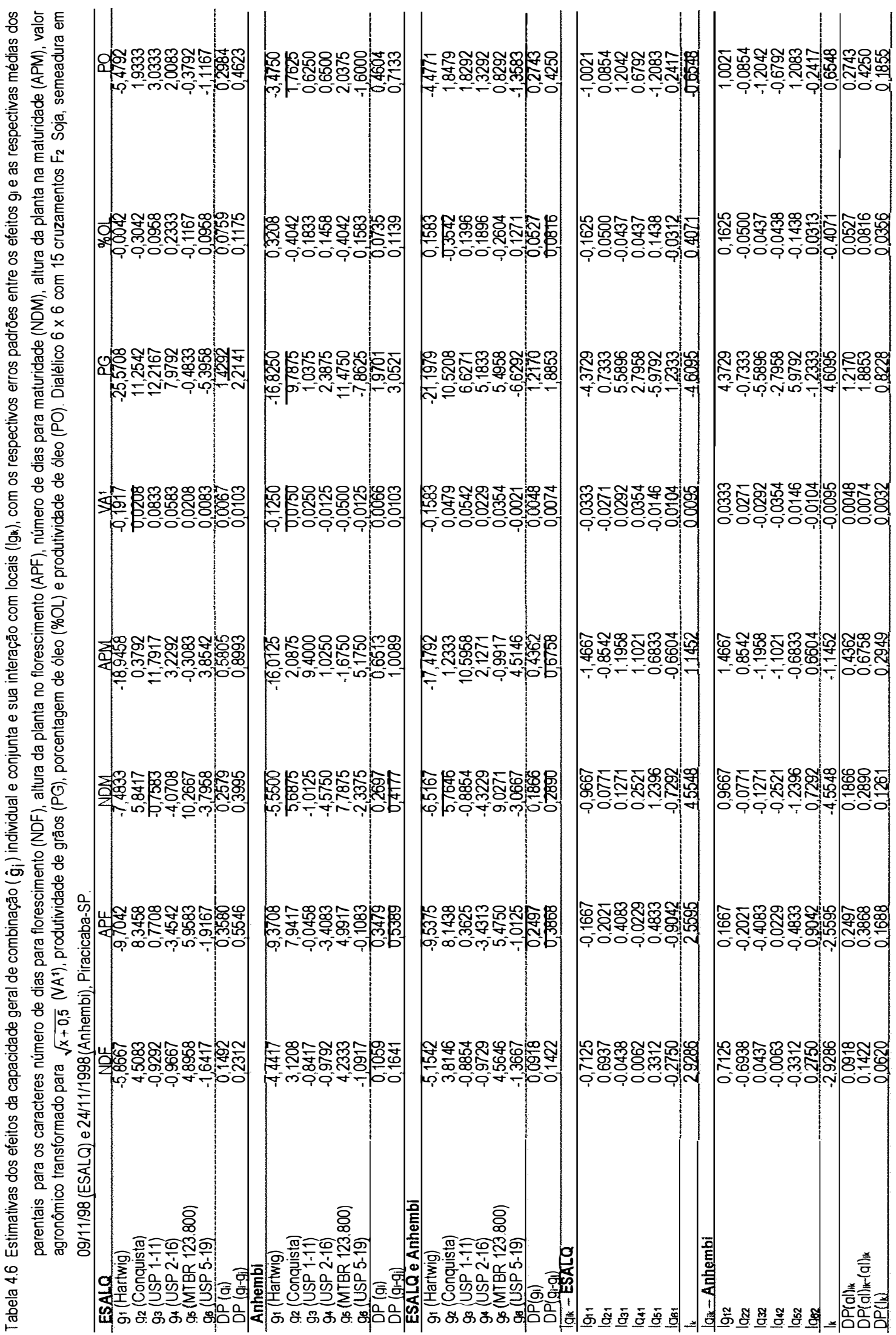




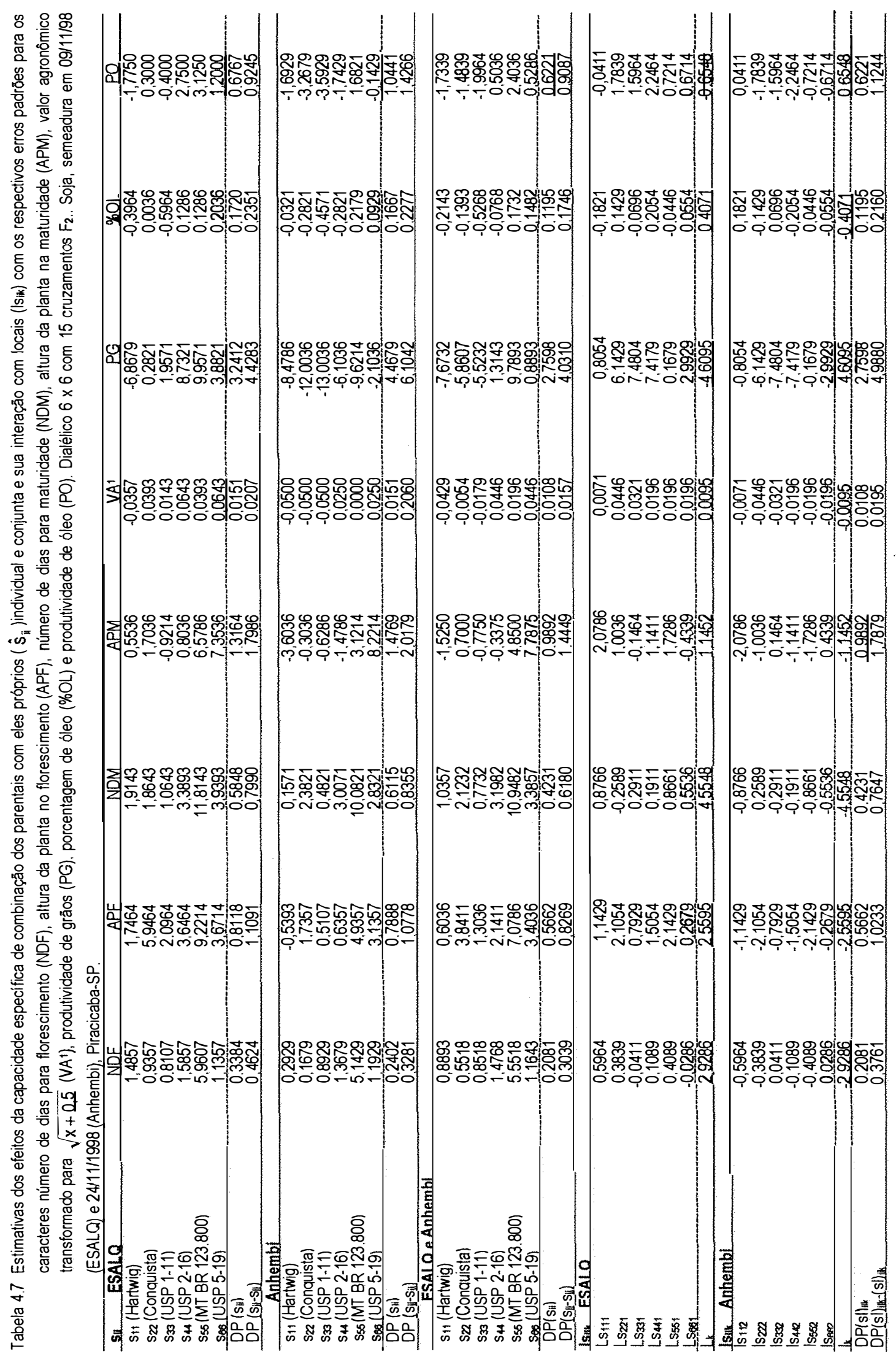




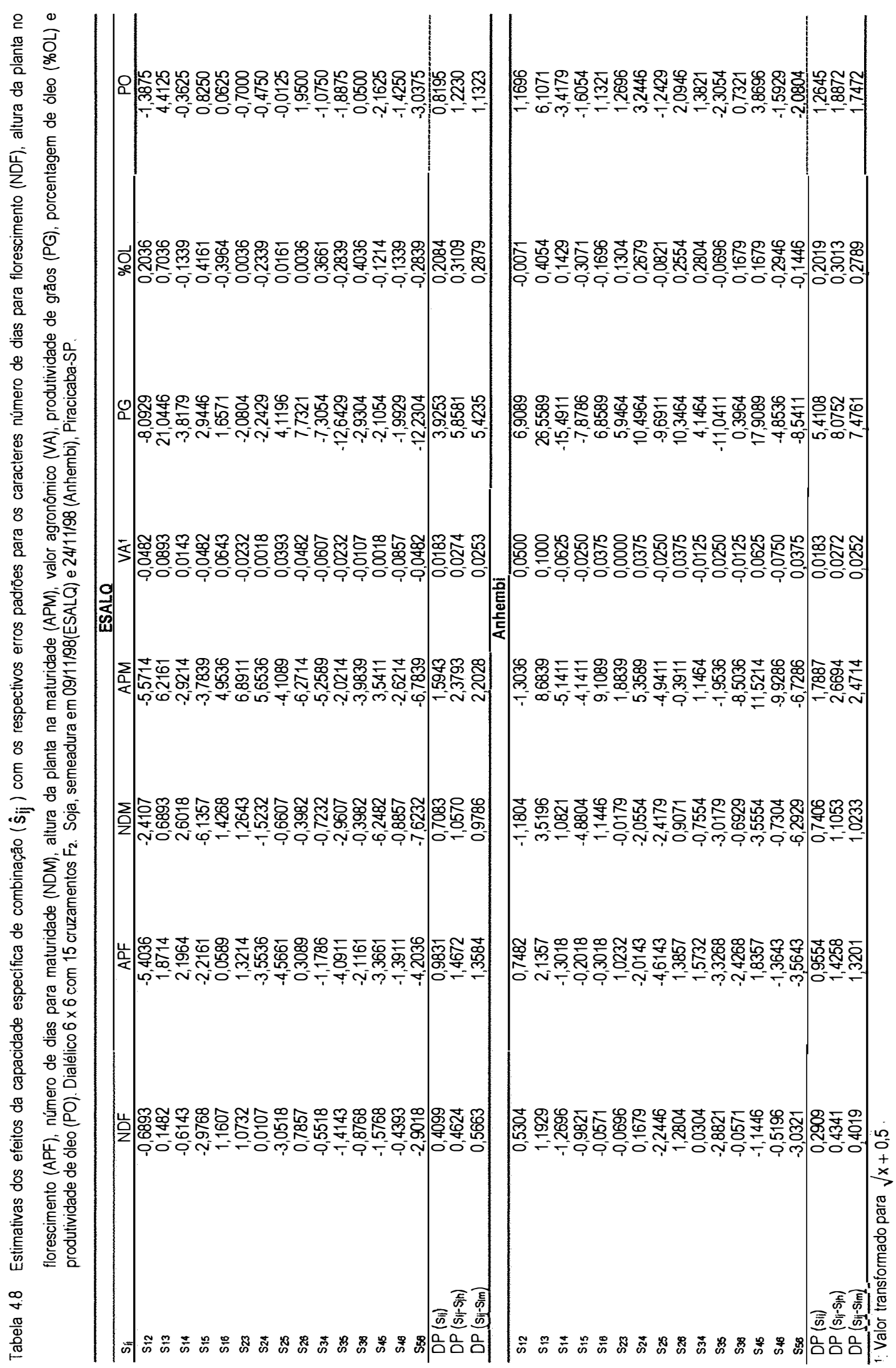




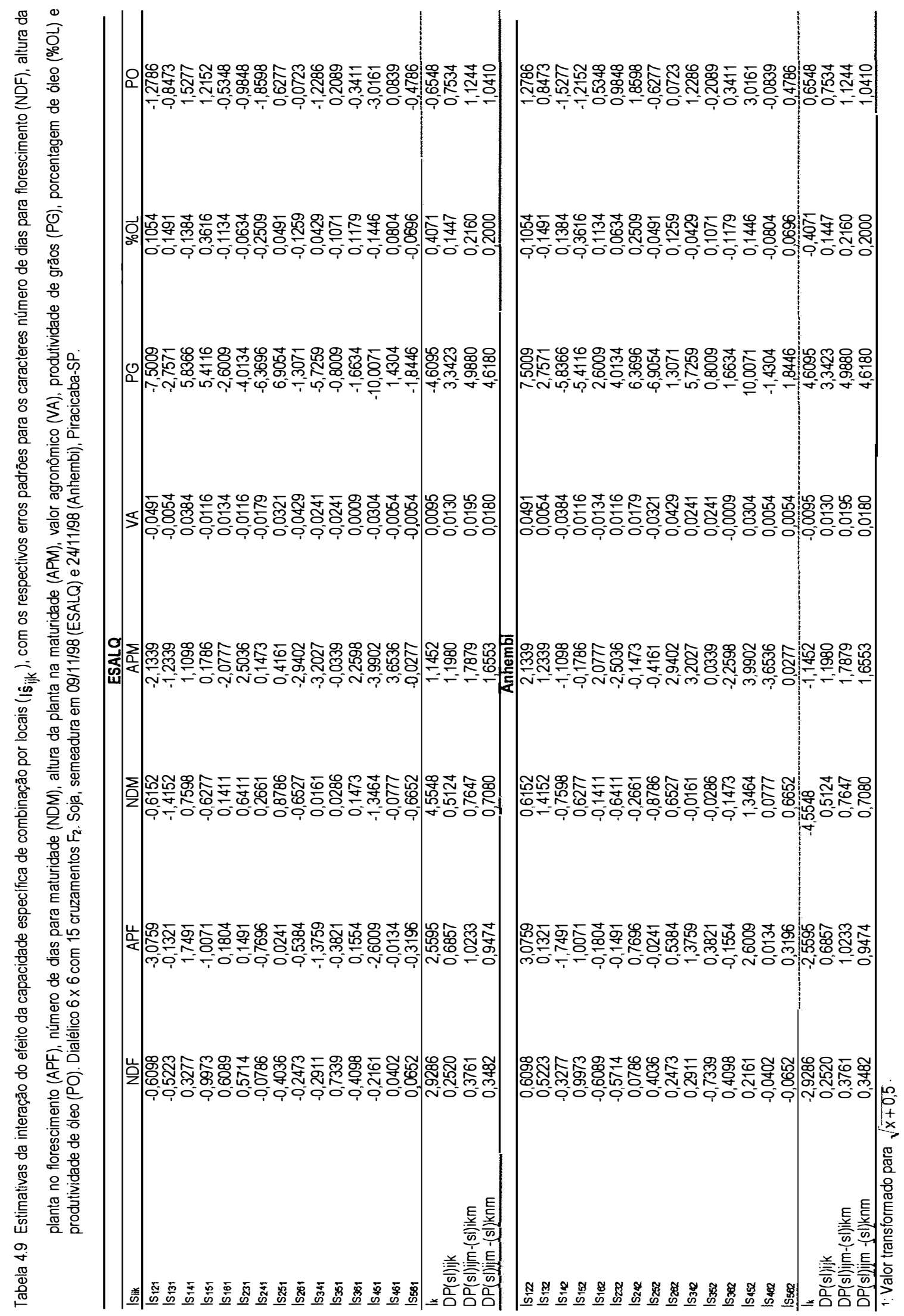




\section{ANÁLISE DIALÉLICA DE HAYMAN ENTRE GENÓTIPOS DE SOJA}

\section{RESUMO}

Foi efetuada análise dialélica através da metodologia de Hayman, envolvendo seis parentais de soja (1) Hartwig, (2) USP 1-11, (3) Conquista, (4) USP 2-16, (5) MT BR 123.800 e (6) USP 5-19 e suas 15 combinações na geração $F_{2}$. Estes parentais têm em comum genes para a resistência a doenças, principalmente ao nematóide de cisto da soja. Os 21 tratamentos foram avaliados no delineamento experimental de blocos ao acaso com seis repetições por local (ESALQ e Anhembi) na safra de 1998/99. Os dados foram coletados nos seguintes caracteres: número de dias para o florescimento (NDF), altura da planta no florescimento (APF), número de dias para a maturidade (NDM), altura da planta na maturidade (APM), produtividade de grãos $(P G)$, teor de óleo nas sementes (\%OL) e Produtividade de óleo por planta (PO). Um dos requisitos da metodologia de Hayman é a independência gênica entre os parentais, o qual pode ser alcançado através do uso de parentais originados de regiões geográficas distintas; nesta pesquisa observou-se que parentais de origem geográficas muito diferentes, principalmente em latitude por exemplo 'Hartwig' (ao redor de 40 ${ }^{\circ}$ Norte) versus 'Conquista' (ao redor de $15^{\circ}$ Sul) podem ter provocado desvios significativos de modelos, cujos ajustes somente foram possiveis com a retirada de alguns parentais do dialelo. Efeito de locais e suas interações influenciaram fortemente as estimativas dos parâmetros genéticos. A análise numérica detectou sobredominância para NDM, \%OL e PO na ESALQ e para a maioria dos caracteres (exceto APF) em Anhembi. Efeitos genéticos aditivos também foram significativos em todos os caracteres na ESALQ, enquanto que em Anhembi apenas o caráter APM foi exceção. A análise gráfica detectou sobredominância para todos os caracteres e, para a maioria, não foi possivel estimar 0 limite teórico de seleção. Os coeficientes de determinação genotípica no sentido amplo foram superiores a 0,90 para a maioria dos caracteres nos dois locais, com exceção do \%OL na 
ESALQ; já os coeficientes de determinação genotipica no sentido restrito foram muito variáveis em magnitude de um local para outro.

\section{HAYMAN'S DIALLEL ANALYSIS AMONG SOYBEAN GENOTYPES}

\section{SUMMARY}

Hayman's genetic analysis was performed, using six soybean parents [(1) Hartwig, (2) USP 1-11, (3) Conquista, (4) USP 2-16, (5) MTBR 123.800 and (6) USP 5-19] and their 15 combinations in the $F_{2}$ generation. These parents have in common genes for diseases resistance, mainly to soybean cyst nematode. The 21 treatments were evaluated through a randomized complete block design with six replications in two localities (ESALQ and Anhembi), during the 1998/99 crop season. Data were collected for the following traits: number of days to flowering (NDF), plant height at flowering (APF), number of days to maturity (NDM), plant height at maturity (APM), agronomic value (VA), seed yield (PG), seed oil content $(\% O L)$ and oil yield (PO). One requirement of Hayman's methodology is the genic independence among the parents, with can be fulfilled by using parents originated in different geographic regions. It was observed that parents from very distant regions, mainly in terms of latitude, like for example 'Hartwig' around $40^{\circ}$ North versus 'Conquista' around $15^{\circ}$ South, can have caused significative deviations of model, which adjustments only were reached after taking out some parents from the diallel. The locality effects and their interactions had strong influences on the estimates of genetic parameters. The numeric analysis detected overdominance for NDM, \%OL, and PO at ESALQ; and, for all traits, except APF, at Anhembi. The addictive genetic actions was significant too for all characters at ESALQ, while at Anhembi APM was the exception. Graphic analysis detected overdominance for all traits, and for most of them it was not possible to estimate the theoretical limit of selection. The genetic determination coefficients, in the broad sense, was superior to 0.90 for most of the traits, in the two localities, except for \%OL at ESALQ; the narrow sense coefficient was very variable in magnitude between localities. 


\subsection{INTRODUÇÃO}

A soja é considerada a mais importante oleaginosa cultivada no mundo e ocupa uma posição de destaque no agronegócio do Brasil, tendo alcançado uma produção de 31 milhões de toneladas de grãos na safra de 1998/99 (CONAB, 2000). Desse modo, para atender à crescente demanda por cultivares, é necessário o conhecimento do potencial genético dos parentais para produzir progênies com características que aumentem o potencial produtivo e a qualidade comercial do produto. Para aumentar a produtividade é necessário envolver genótipos altamente produtivos com resistência a estresses bióticos e abióticos. 0 sucesso do melhoramento para determinados caracteres depende do conhecimento da estrutura genética dos mesmos e uma das formas de se obter esse conhecimento é através dos dialelos (Raut et al., 2000).

$O$ termo dialelo tem sido utilizado para designar um conjunto de combinações, resultantes dos cruzamentos entre $n$ parentais (linhagens, cultivares). Os experimentos podem incluir os parentais, os hibridos e os cruzamentos recíprocos, além de poder envolver várias gerações relacionadas, tais como $\mathrm{F}_{2} \mathrm{e}$ outras com endogamia mais avançada.

Existem várias metodologias de análise dialélica que avaliam o delineamento genético, promovendo estimativas de parâmetros úteis na seleção de parentais para hibridação e no entẹndimento dos efeitos genéticos envolvidos na herança dos caracteres. Entre as metodologias utilizadas pode-se destacar a proposta por Hayman (1954b), que fornece informações sobre os mecanismos básicos da herança do caráter em estudo, dos valores genéticos dos parentais utilizados e do limite de seleção.

Em geral, várias gerações devem ser cultivadas e muitos esforços precisam ser despendidos até que se encontrem as combinaçães desejáveis. Um.melhor conhecimento das relações genéticas entre os parentais envolvidos em cruzamentos poderia ser útil na identificação de híbridos elou cruzamentos promissores. Uma abordagem deste problema foi desenvolvida por Hayman (1954a, b, 1958) descrevendo um método de análise que permite uma estimativa rápida e geral das relações genéticas entre parentais que compõem os cruzamentos dialélicos (Miranda et al., 1982)

O método de Hayman além de detectar o número relativo de genes recessivos e dominantes presentes nos parentais, permite também estimar outros parâmetros genéticos 
importantes no processo de seleção. Através de expressões genéticas baseadas em um modelo aditivo-dominante pode-se estimar vários parâmetros, tais como: médias, variâncias, covariâncias (Hernández \& Vega, 1996).

No presente trabalho utilizou-se a metodologia de Hayman para a análise genética de cruzamentos dialélicos entre seis parentais de soja e, com isso, estimar parâmetros genéticos para caracteres de importância agronômica.

\subsection{MATERIAL E MÉTODOS}

\subsubsection{Material genético}

Seis genótipos de soja: (1) Hartwig, (2) USP 1-11, (3) Conquista, (4) USP 2-16, (5) MT BR 123.800 e (6) USP 5-19 foram cruzados em dialelo completo sem reciprocos, originando n(n1)/2=15 cruzamentos. Estes parentais foram escolhidos pela produtividade de grãos, desempenho agronômico e resistência a doenças (Tabela 3.1). Os experimentos foram conduzidos, na safra de 1998/99, em dois locais, ESALQ e Anhembi, localizados no municipio de Piracicaba-SP, a $22^{\circ} 42^{\prime} 30^{\prime \prime}$ de latitude Sul, $47^{\circ} 39^{\prime} 00^{\prime \prime}$ de longitude Oeste e $543 \mathrm{~m}$ de altitude. Os dois locais são bem contrastantes: ESALQ, compreende área localizada no Departamento de Genética, com solo do tipo terra roxa estruturada, textura argilosa, relevo ondulado; Estação Experimental Anhembi: caracterizada por solo aluvial distrófico, textura médio-arenosa, relevo plano, situado a $60 \mathrm{~km}$ da sede ESALQ.

Os 21 tratamentos foram constituidos por seis parentais e 15 cruzamentos $F_{2}$, avaliados no delineamento experimental de blocos ao acaso com seis repetições por local (ESALQ e Anhembi). A parcela foi representada por 12 covas de plantas individuais espaçadas de $0,80 \mathrm{~m} x$ $0,80 \mathrm{~m}$, totalizando uma área útil de $7,68 \mathrm{~m}^{2} ;$ no total de seis repetições foram pesquisadas 144 plantas $F_{2}$ de cada cruzamento. A semeadura foi realizada no mês de novembro, sendo semeadas 12 sementes por cova e, após 15 dias, foi realizado $o$ desbaste para uma planta por cova. 


\subsubsection{Caracteres avaliados}

A partir dos dados coletados de plantas individuais foram avaliados os mesmos caracteres citados na parte referente a material e métodos do capitulo 3 , com exceção de VA.

\subsubsection{Análises dialélica (Hayman, 1958)}

As análises estatisticas dos dados foram realizadas utilizando-se os programas computacionais SAS (SAS INSTITUTE INC, 1997) e GENES (Cruz, 1997). As bases teóricas para essa análise foram desenvolvidas inicialmente para geração $F_{1}$ (Hayman, 1954a, b; Jinks, 1954) e posteriormente para a geração $F_{2}$ (Hayman, 1958; Jinks, 1956). A aplicação dessa metodologia baseia-se nas seguintes suposições:

1. Segregação diplóide;

2. Ausência de efeitos reciprocos entre cruzamentos;

3. Ação independente de genes não alélicos (ausência de epistasia);

4. Ausência de alelos múltiplos;

5. Linhagens parentais homozigóticas;

6. Distribuição independente dos genes nos parentais

A primeira suposição é normal da espécie, a 2 e a 5 é provável que sejam razoavelmente atendidas. A 3 que se refere à epistasia, o próprio modelo testa a significância dos desvios e só deve ser aplicado se os mesmos não forem significativos. Contudo as de número 4 e 6 poderão apresentar alguns desvios.

A partir da tabela dialélica foram estimadas as seguintes variâncias e covariâncias:

Variância dos genótipos parentais $\left(V_{p}\right)$,

$$
\hat{V}_{p}=\frac{1}{n-1}\left[\sum_{i} Y_{i i}^{2}-\frac{1}{n} Y_{p}^{2}\right]
$$

Variância dentro da linha ou coluna i da tabela dialélica $\left(V_{i}\right)$,

$$
\hat{V}_{i}=\frac{1}{n-1}\left[\sum_{i} Y_{i j}^{2}-\frac{1}{n} Y_{i}^{2}\right]
$$


Média das variâncias estimadas dentro das linhas ou colunas $(\bar{V})$,

$$
\overline{\hat{V}}=\frac{1}{n} \sum_{i} \hat{V}_{i}
$$

Variância entre as médias das linhas ou colunas $\left(V_{M}\right)$,

$$
\hat{V}_{M}=\frac{1}{n-1}\left[\sum_{i} \bar{Y}_{i}^{2}-\frac{1}{n}\left(\sum_{i} \bar{Y}_{i}\right)^{2}\right]
$$

Covariância entre a diagonal dos parentais e os genótipos da i-ésima linha $\left(W_{i}\right)$,

$$
\hat{W}_{i}=\frac{1}{n-1}\left[\sum_{j} Y_{i j} Y_{i j}-\frac{1}{n} \sum_{j} Y_{i j} \sum_{j} Y_{i j}\right]
$$

Média das covariâncias entre parentais e a i-ésima linha $(\bar{W})$,

$$
\overline{\hat{W}}=\frac{1}{n} \sum_{i} \hat{W}
$$

\subsubsection{Teste de suficiência do modelo aditivo-dominante}

Essa metodologia só pode ser usada quando os dados atendem às restrições do modelo genético. Para isso, alguns testes precisam ser feitos. No primeiro teste, a variação de $\hat{W}_{i}-\hat{V}_{i}$ foi avaliada por meio da análise de variância, ou seja, as variâncias e covariâncias foram calculadas para cada uma das 15 combinações, em cada uma das repetições; em seguida obteve-se a diferença de $\hat{W}_{i}-\hat{V}_{i}$ e procedeu-se a análise destas diferenças em blocos ao acaso, considerando-se como fonte de variação as repetições e as linhas da tabela dialélica. Quando o teste F foi não-significativo para "linhas", a hipótese da homogeneidade foi aceita. Outro teste foi realizado com base na estatística $t$, contrastando o coeficiente de regressão $b$ com a unidade, ponderando-se $\hat{W}_{i}$ e $\hat{V}_{i}$; se o teste acusar significância verifica-se a insuficiência do modelo, sendo recomendada a eliminação de parentais ou a mudança de escalas das variáveis. Feito isso, deve-se realizar um novo teste para verificar se a suficiência do modelo foi estabelecida.

Neste trabalho para os caracteres em que o teste $F$ foi significativo, indicando heterogeneidade das diferenças $\hat{W}_{i}-\hat{V}_{i}$, ou o coeficiente de regressão $b$ diferiu da unidade, fez- 
se a análise das subtabelas dialélicas com (n-1)x(n-1) e ainda (n-2)x(n-2) (Hayman, 1954b). As análises genéticas só foram realizadas quando as restrições da metodologia foram razoavelmente atendidas.

A partir dessas variâncias e covariâncias, foi realizada a análise gráfica que possibilita a visualização genética relativa dos parentais. Essa análise è realizada com base na: a) regressão de $W_{i}$ sobre $V_{i}$, que permite 0 estabelecimento da seguinte equação $\left.W_{i}=a+b V_{i} ; b\right)$ parábola limitante obtida pela equação $W^{2}=V_{p} . V_{i}$; onde a é o ponto de interseção da reta com o eixo das ordenadas e b é o coeficiente de regressão linear, obtidos pelas expressões:

$$
\begin{aligned}
& b=\frac{\operatorname{Cov}\left(W_{i} V_{i}\right)}{\operatorname{Var}\left(V_{i}\right)} \\
& a=\bar{W}_{i}-b \bar{V}_{i}
\end{aligned}
$$

O erro de $b$ foi estimado através da seguinte fórmula:

$$
s_{b}=\sqrt{\frac{\operatorname{Var} W_{i}-b \operatorname{Cov}\left(W_{i}-V_{i}\right)}{(n-2) \operatorname{var} V_{i}}}
$$

$O$ teste de significância da hipótese $\mathrm{H}_{0}: b=1$ foi realizado através do teste " $\mathrm{t}$ ", ao nível de $1 \%$ e $5 \%$ de probabilidade com $n-2$ graus de liberdade.

Após a análise gráfica fez-se uma análise numérica do cruzamento dialélico, sendo estabelecidas as equações para o cálculo das estimativas dos parâmetros $D, F, \mathrm{H}_{1}$ e $\mathrm{H}_{2}$, em que:

$\hat{D}$ : estimativa do componente de variância devido aos efeitos gênicos aditivos;

$\hat{F}$ : estimativa do componente genético correspondente à covariância entre os efeitos aditivos e dominantes dos genes. Indica a freqüência relativa dos alelos dominantes e recessivos na população parental. F será positivo se os alelos dominantes tiverem maior freqüência que os recessivos e negativo se for ao contrário;

$\hat{H}_{1}$ : estimativa do componente de variância devido aos efeitos de dominância dos genes;

$\hat{H}_{2}$ : estimativa do componente de variância genética dominante corrigido para a distribuição genética. Indica a assimetria dos efeitos positivos e negativos dos 
genes. Teoricamente $\mathrm{H}_{1}>\mathrm{H}_{2}$, se $\mathrm{H}_{1}=\mathrm{H}_{2}$ indica simetria entre os genes de efeito positivo e aqueles de efeito negativo;

Para a estimação dos parâmetros $D, F, H_{1}$ e $H_{2}$ foram usadas as seguintes fórmulas:

$$
\begin{aligned}
& \hat{D}=\hat{V}_{p}-\varepsilon \\
& \hat{F}=4 \hat{V}_{p}-8 \overline{\hat{W}}-4(n-2) \varepsilon \\
& n \\
& \hat{H}_{1}=4 \hat{V}_{p}+16 \overline{\hat{V}}_{i}-16 \overline{\hat{W}}_{i}-\frac{4(5 n-4) \varepsilon}{n} \\
& \hat{H}_{2}=16 \overline{\hat{V}}_{i}-16 \hat{V}_{M}-\frac{16(n-1) \varepsilon}{n} \\
& \varepsilon: \text { resíduo geral. }
\end{aligned}
$$

O erro padrão de cada componente genético foi estimado calculando-se a variância $\left(\sigma_{d}^{2}\right)$ pela seguinte fórmula (Hayman, 1954b).

$$
\sigma_{d}^{2}=\frac{1}{2} \hat{V}\left(\hat{W}_{i}-\hat{V}_{i}\right)
$$

$E$, depois, multiplicando-se essa variância pelo multiplicador especifico para cada parâmetro e dimensão apresentada por Ferreira (1985). A significância de cada efeito pode ser testada pela estatistica " 4 " com n-2 graus de liberdade. 0 valor de " $"$ " é obtido pela divisão da estimativa do parâmetro pelo respectivo erro-padrão.

A partir dos componentes da variância genética $D, F, H_{1}$ e $H_{2}$ foram estimados os seguintes parâmetros de uma população a ser formada pela recombinação dos seis parentais:

1. Grau médio de dominância (gm̂d)

$$
\begin{aligned}
& g \hat{m} d=\sqrt{\frac{\hat{H}_{1}}{\hat{D}}} \\
& \text { gî̀d = } 0 \text { (ausência de dominância) } \\
& 0<\text { gm̂d }<1 \text { (dominância parcial) } \\
& \text { gm̂d }=1 \text { (dominância completa) } \\
& \text { gînd }>1 \text { (sobredominância) }
\end{aligned}
$$


2. Proporção entre genes dominantes (d) e recessivos (r)

$$
\frac{\hat{d}}{\hat{r}}=\frac{\sqrt{4 \hat{D} \hat{H}_{1}}+F}{\sqrt{4 \hat{D} \hat{H}_{1}}-F}
$$

$\frac{\hat{d}}{\hat{r}} \cong 1$ (distribuição uniforme, nos parentais, dos genes dominantes e recessivos)

$\frac{\hat{d}}{\hat{r}}>1$ (maior frequência dos genes dominantes em relação aos recessivos, nos parentais)

$\frac{\hat{d}}{\hat{r}}<1$ (maior frequência dos genes recessivos em relação dominantes aos, nos parentais)

3. Produto das freqüências médias dos alelos de efeitos positivos e negativos nos locos onde ocorre dominância (simetria).

$$
\mu v=\frac{\hat{H}_{2}}{4 \hat{H}_{1}}
$$

O valor próximo de 0,25 indica que os alelos com efeitos positivos e os alelos com efeitos negativos estão distribuidos uniformemente nos parentais. Valores diferentes de 0,25 indicam distribuição desuniforme tanto dos alelos que contribuem para aumentar como para diminuir a expressão do caráter.

4. Coeficiente de determinação genotipica no sentido restrito $\left(h^{2}{ }_{r}\right)$ e no sentido amplo $\left(h^{2}{ }_{a}\right)$ foram usadas as fórmulas apresentadas por Mather \& Jinks (1982).

$$
\begin{aligned}
& \mathrm{h}_{\mathrm{r}}^{2}=\frac{\frac{1}{2} \hat{\mathrm{D}}+\frac{1}{2} \hat{\mathrm{H}}_{1}-\frac{1}{2} \hat{\mathrm{H}}_{2}-\frac{1}{2} \hat{\mathrm{F}}}{\frac{1}{2} \hat{\mathrm{D}}+\frac{1}{2} \hat{\mathrm{H}}_{1}-\frac{1}{4} \hat{\mathrm{H}}_{2}-\frac{1}{2} \hat{\mathrm{F}}+\frac{1}{\mathrm{r}} \varepsilon} \\
& \mathrm{h}_{\mathrm{a}}^{2}=\frac{\frac{1}{2} \hat{\mathrm{D}}+\frac{1}{2} \hat{\mathrm{H}}_{1}-\frac{1}{4} \hat{\mathrm{H}}_{2}-\frac{1}{2} \hat{\mathrm{F}}}{\frac{1}{2} \hat{\mathrm{D}}+\frac{1}{2} \hat{\mathrm{H}}_{1}-\frac{1}{4} \hat{\mathrm{H}}_{2}-\frac{1}{2} \hat{\mathrm{F}}+\frac{1}{\mathrm{r}}} \\
& \mathrm{r}=\text { número de repetições }
\end{aligned}
$$


Com base na expressão média do caráter $\left(\bar{Y}_{i}\right)$ e na soma da covariância e variância $\left(W_{i}+V_{i}\right)$ foi estimado o limite de seleção. Os valores das variâncias e covariâncias correspondentes ao genótipo completamente dominante são $V_{D}$ e $W_{D}$ e dos genótipos completamente recessivos são $V_{R}$ e $W_{R}$. Onde:

Reta: $\hat{\mathbf{W}}_{\mathrm{i}}=\hat{\mathrm{a}}+\hat{\mathrm{b}} \hat{\mathrm{V}}_{\mathrm{i}}$

Parábola: $\hat{\mathrm{W}}_{\mathrm{i}}^{2}=\hat{\mathrm{V}}_{\mathrm{p}} \hat{\mathrm{V}}_{\mathrm{i}}$

A interseção da reta com a parábola pode ser estimada considerando-se a igualdade: $\hat{W}_{i}^{2}=\frac{\hat{V}_{p}\left(\hat{W}_{1}-\hat{a}\right)}{\hat{b}}$, as raizes da equação fornecem $\hat{W}_{R}, \hat{W}_{D}$, e após substituição na equação da reta obtêm-se $V_{R} e V_{D}$.

A equação de predição do valor médio de um parental é dada pela equação de regressão de $Y_{i i}$ em função de $\hat{W}_{i}+\hat{V}_{i}$, onde:

$$
\begin{aligned}
& \hat{Y}_{\mathrm{ii}}=\hat{a}_{0}+\hat{a}_{1}\left(\hat{W}_{\mathrm{i}}+\hat{\mathrm{V}}_{\mathrm{i}}\right) \\
& \hat{a}_{1}=\frac{\operatorname{Côv}\left(\mathrm{Y}_{\mathrm{i}}, \hat{\mathrm{W}}+\hat{\mathrm{V}}\right)}{\hat{\mathrm{V}}(\hat{\mathrm{W}}+\hat{\mathrm{V}})} \\
& \hat{\alpha}_{0}=\bar{Y}_{\mathrm{ii}}-\hat{\alpha}_{1}(\overline{\hat{\mathrm{W}}}+\overline{\hat{V}}) \\
& \hat{Y}_{D}=\hat{a}_{0}+\hat{a}_{1}\left(\hat{\mathrm{W}}_{\mathrm{D}}+\hat{\mathrm{V}}_{\mathrm{D}}\right) \\
& \hat{\mathrm{Y}}_{\mathrm{R}}=\hat{a}_{0}+\hat{\alpha}_{1}\left(\hat{\mathrm{W}}_{\mathrm{R}}+\hat{\mathrm{V}}_{\mathrm{R}}\right)
\end{aligned}
$$

\subsection{RESULTADOSE DISCUSSÃO}

Na Tabela 5.1 são apresentados o coeficiente de regressão (b) de W (covariâncias) em função de $V$ (variâncias) e a análise de variância das diferenças $\left(\hat{W}_{i}-\hat{V}_{i}\right)$, correspondentes aos testes de suficiência do modelo aditivo-dominante, as estimativas dos componentes genéticos aditivos e dominantes $\left(D, F, H_{1}\right.$ e $H_{2}$ ) e os parâmetros genéticos ( $g m d, d / r, \mu v, h_{r}^{2}, h_{a}^{2}$ ) para cada local. Para todos os caracteres, os testes de $b=1$ para os coeficientes de regressão e as análises das diferenças $\left(\hat{W}_{i}-\hat{V}_{i}\right)$ foram não-significativos, fatos estes que indicaram a eficiência do 
modelo aditivo-dominante. No entanto, para se obter a suficiência do modelo aditivo-dominante para alguns caracteres, foi necessário a eliminação de um ou dois parentais nos dois locais; isto foi mais constante na ESALQ que em Anhembi. Após este procedimento de ajuste observou-se a eficiência do modelo. Outros autores também verificaram a inadequação do modelo: Leffel \& Weiss, (1958) para NDF e APM; Kaw \& Menon (1983) para PG e APM; Freire Filho (1988) para NDF, APF e APM. Soldini (1998) também utilizou a eliminação de parentais como medida de ajuste para o caráter \%OL.

Um aspecto importante em relação aos desvios do modelo aditivo-dominante, refere-se ao parental Conquista empregado no esquema dialélico, cuja eliminação permitiu 0 ajuste dos dados para alguns caracteres. Este comportamento também se repetiu, em menor intensidade, com os parentais Hartwig e MTBR 123.800. No caso de Conquista e MTBR 123.800 isso ocorreu provavelmente porque estes genótipos são indicados para regiões de baixa latitude e possuem genes tolerância ao fotoperiodo e com resistência ao Nematóide de Cisto da Soja (NCS), já no caso da Hartwig por ser um genótipo exótico e bastante divergente. Isto indica que a inclusão, nos cruzamentos, de genótipos selecionados para caracteres especificos e divergentes geograficamente, leva à manifestação de efeitos genéticos pouco comuns nos cruzamentos de adaptado $\times$ adaptado.

A seleção de progênies para caracteres especificos, dentro de programas de melhoramento, pode provocar assimetrias acentuadas na distribuição dos genes nos parentais. Estes desvios podem ser estimados pelo coeficiente de parentesco (Vello et al., 1988; Kisha \& Diers, 1997). Segundo Soldini (1998), para o caso do cultivar Hartwig, a transferência de genes de resistência ao Nematóide de Cisto da Soja (NCS) derivados da PI 437.654, ligados a outros alelos não presentes no "pool" de genes adaptados, ou à permanência de $6,25 \%$ do genoma da PI 437.654, podem ser partes das causas de falta de ajuste do modelo genético. $O$ uso de genótipos exóticos é uma estratégia para incorporação de novos genes e para a ampliação da variabilidade, como foi demonstrado pela associação inversa entre coeficiente de parentesco e variância genética, através de marcadores moleculares (Manjarrez-Sandoval et al., 1996). No entanto, é importante salientar que as dificuldades de incorporar exclusivamente os genes de interesse podem retardar os beneficios promovidos pela transferência desses genes aos genótipos adaptados, em termos de ampliação da variabilidade genética. 
De acordo com Vello et al. (1984), em populações com base genética ampla (até 80 parentais, sendo 40 adaptados e 40 exóticos pertencentes à espécie cultivada), a introdução de $25 \%$ de genes de genótipos exóticos levou ao aumento máximo da variabilidade genética e à diminuição mínima na-média de produtividade da população; estes autores salientaram ainda a importância dos parentais exóticos serem previamente selecionados para caracteres adaptados.

A utilização da metodologia de Hayman resulta em informações bastante úteis ao melhoramento, embora para atender todas as suas pressuposições precisou-se usar vários artificios sugeridos em literatura, tais como eliminação dos genótipos que dificultam a análise por serem diferentes do restante. Há evidências de que seria ideal utilizar nos cruzamentos dialélicos parentais divergentes geneticamente, mas de origens geográficas não tão diferentes, procurando-se aqueles adaptados às mesmas condições geográficas (latitude, altitude) e com boas características agronômicas. Como esta análise é bastante sensivel e detecta pequenas diferenças, talvez seja melhor utilizar diferentes grupos de cruzamentos, de modo que a realização da análise e as estimativas dos parâmetros genéticos provenientes da mesma não sejam prejudicados mediante a eliminação de um grande número de parentais.

As estimativas dos componentes de variância indicaram que os efeitos aditivos (D) foram significativos $(p<0,05$ e $p<0,01)$ para todos os caracteres nos dois locais, exceto para APM em Anhembi, indicando que os parentais apresentam variabilidade genética aproveitável na seleção de progênies derivadas dos cruzamentos entre eles. Resultados similares foram obtidos por Freire Filho (1988) em dialelo completo e por Soldini (1998) em dialelo parcial. As estimativas dos componentes de variância correspondentes aos efeitos de dominância $\left(\mathrm{H}_{1}\right.$ e $\left.\mathrm{H}_{2}\right)$ mostraram efeitos significativos $(p<0,05$ e $p<0,01)$ para a maioria dos caracteres nos dois locais, exceto NDF, APF e PO na ESALQ; portanto, há evidências da ocorrência também de ação gênica dominante na maioria dos caracteres. A estimativa de $F$, que corresponde à freqüência relativa dos alelos dominantes e recessivos na população parental, foi positiva e significativa $(p<0,05$ e $p<0,01)$ para todos os caracteres, com exceção apenas dos caracteres NDF, APF na ESALQ e \%OL, PO nos dois locais. Esses dois últimos caracteres não apresentaram significância para 0 parâmetro $\mathrm{F}$, sendo que o $\mathrm{F}$ para \%OL foi negativo e não-significativo no local Anhembi. Isso mostra a predominância de alelos dominantes na determinação genética da maioria destes caracteres. 
A análise do grau médio de dominância ( $g m d$ ) mostrou a existência de dominância completa ( $g m \mathrm{~m} \cong 1$ ) e sobredominância ( $g m \mathrm{~m}>1$ ) para a maioria dos caracteres, tanto na ESALQ quanto em Anhembi; houve exceção de NDF, APF, APM e PG (ESALQ) e de APF (Anhembi), os quais apresentaram dominância parcial (0<gmd<1). Na ESALQ, os caracteres NDF, APF, APM e PG mostraram ação aditiva superior à dominante; sendo os valores do gmd inferiores à unidade, há evidências de dominância parcial nestes caracteres. A predominância de efeitos gênicos aditivos na maioria dos caracteres é um indicativo da facilidade de se encontrarem genótipos geneticamente superiores durante o processo de seleção (Mather \& Jinks, 1984). Já em Anhembi ocorreu o inverso, sendo que a maioria dos caracteres, com exceção de APF, apresentou ação aditiva inferior a dominante, com valores de gmd superiores à unidade, indicando a presença de dominância completa e/ou sobredominância. Essas diferenças ao nivel de componentes e parâmetros genéticos entre ESALQ e Anhembi indicam que a fonte de variação "locais" influencia o controle genético de importantes caracteres agronômicos nestes cruzamentos. De fato, Sharma et al. (1993) relataram que o sistema de cultivo (solteiro e consórcio) influenciou o controle genético da produtividade e de caracteres a ela associados.

A proporção de genes dominantes e recessivos (d/r) indicou que há maior freqüência de alelos dominantes tanto na ESALQ $(1,02 \leq \mathrm{d} / r \leq 2,63)$ quanto em Anhembi $(0,72 \leq \mathrm{d} / \mathrm{r} \leq 2,62)$, sendo que as caracteristicas NDM (ESALQ e Anhembi), APM (ESALQ) e \%OL (Anhembi) apresentaram uma distribuição relativamente uniforme dos genes dominantes e recessivos. A simetria $(\mu v)$, ou seja, o produto das frequeências médias dos alelos de efeitos positivos $e$ negativos nos locos com dominância, foi de 0,25 ou próximo deste valor apenas para os caracteres NDF $(\mu v=0,25)$ e PO ( $\mu v=0,23)$ na ESALQ e PG ( $\mu v=0,21)$ e PO ( $\mu v=0,23)$ em Anhembi; os demais caracteres apresentaram distribuição assimétrica ou desuniforme, tanto dos alelos que contribuem para aumentar quanto daqueles que diminuem a expressão do caráter. Os coeficientes de determinação genotipica no sentido restrito $\left(h_{r}{ }^{2}\right)$ variaram bastante de um local para o outro, apresentando valores baixos para os caracteres NDM (ESALQ e Anhembi), APM e PG (Anhembi). Já as coeficientes de determinação genotipica no sentido amplo $\left(h^{2} a\right)$ foram altas e semelhantes nos dois locais.

Tentando particularizar os caracteres, tanto pela análise numérica como gráfica, podese dizer que, nos caracteres NDF e APF, os componentes de variância genética $F, H_{1}$ e $H_{2}$ foram 
não-significativos na ESALQ e D, F, $\mathrm{H}_{1}$ e $\mathrm{H}_{2}$ significativos ( $p<0,01$ ) em Anhembi. Para NDF, 0 grau médio de dominância (gmd) foi 0,75 na ESALQ, revelando a ocorrência de dominância e 1,07 em Anhembi, com dominância completa. Já APF apresentou dominância parcial nos dois locais, com gmd=0,91 e 0,73 na ESALQ e Anhembi, respectivamente. O valor de $F$ positivo e $d / r$ maior que a unidade indicam que há maior frequência de genes dominantes controlando a expressão do caráter APF. Para 0 caráter NDF, a relação $\mathrm{H}_{2} / 4 \mathrm{H}_{1}=0,25$ e 0,16 na ESALQ e Anhembi, respectivamente, indica que somente na ESALQ os parentais apresentaram uma distribuição uniforme de alelos com efeitos positivos e negativos, conforme pode ser comprovado pela semelhança entre os valores de $\mathrm{H}_{1}$ e $\mathrm{H}_{2}$; 0 coeficiente de determinação genotípica no sentido restrito $\left(h_{r}{ }_{r}\right)$ foi de 0,68 e 0,51 naESALQ e Anhembi, respectivamente; no sentido amplo $\left(h^{2}\right.$ ) foi de 0,99 para NDF. Já para APF, $h^{2}$ apresentou um valor maior em Anhembi $(0,77)$ do que na $\operatorname{ESALQ}(0,59)$.

Esses resultados mostram-se bastante concordantes com os obtidos por Toledo \& Kiihl (1982b), Freire Filho (1988) e Soldini (1998) para NDF. No que se refere aos efeitos aditivos e dominantes, os resultados obtidos neste trabalho estão de acordo com a conclusão obtida por Toledo \& Kiihl (1982b). Estes autores ainda ressaltam que há pelo menos três genes controlando NDF através de efeitos aditivos e dominantes. Para APF, Kaw \& Menon (1983) obtiveram resultados semelhantes na geração $F_{1}$, com valores significativos para $D, F, H_{1}$ e $\mathrm{H}_{2}$ e gmd=0,96. Estes autores também obtiveram $d / r>1$ e $h^{2}$ a de 0,86 , resultados que concordam com os obtidos neste trabalho. Camacho (1971) também obteve valores significativos para as variâncias devido aos efeitos aditivos e de dominância; considerando que a variância de dominância foi bem superior à aditiva, pode-se dizer que os efeitos de dominância foram mais importantes para a expressão de APF, concordando com os resultados obtidos para APF em Anhembi.

Pela análise gráfica (figuras 5.1a e 5.1b), o valor do coeficiente de regressão b não diferiu estatisticamente da unidade nos dois locais e com $\mathrm{R}^{2} \cong 0,99$; estes dois fatos indicam um bom ajuste dos dados à reta da regressão. A correlação positiva entre $\hat{Y}_{i}$ e $\left(\hat{W}_{i}+\hat{V}_{i}\right)$, estimada respectivamente em 0,65 e 0,66 para ESALQ e Anhembi, evidencia que os genes dominantes reduzem a expressão do caráter e isto concorda com os resultados obtidos por Kaw \& Menon (1983) e Toledo \& Kiihl (1982b). A partir do gráfico constata-se que na ESALQ os parentais Hartwig (1) e USP 5-19 (6) contém mais genes dominantes, USP 2-16 (4) é o que contém mais 
genes recessivos, enquanto que o parental USP1-11 (3) situa-se numa posição intermediária. Em Anhembi não houve necessidade de retirar nenhum parental para atender às exigências do modelo genético; os parentais Hartwig (1), Conquista (2), USP1-11 (3), USP 2-16 (4) e USP 5-19 (6) contém mais genes dominantes, enquanto o parental MTBR 123.800 (5) é o que contém mais genes recessivos. Nos dois locais, pode-se observar que os parentais Hartwig (1) e USP 5-19 (6) possuem comportamento semelhante, ambos contém mais genes dominantes, ou seja, apresentaram maior precocidade; realmente, Hartwig foi o parental mais precoce do dialelo (Tabelas 3.8 e 3.9 ).

No que diz respeito a APF (figuras 5.2a e 5.2b) foi também necessário a exclusão de dois parentais na ESALQ para atender ao modelo aditivo-dominante, no que se refere a homogeneidade das diferenças $\left(\hat{W}_{i}-\hat{V}_{i}\right)$. A correlação entre $\hat{Y}_{i}$ e $\left(\hat{W}_{i}+\hat{V}_{i}\right)$ foi de $-0,08$ na ESALQ e -0,31 em Anhembi. Embora os valores sejam baixos, e com $R^{2}$ razoáveis, eles sugerem que os genes dominantes atuam no sentido de incrementar o caráter. Pelos gráficos, observa-se que os parentais com maior número de genes recessivos na ESALQ foram: Hartwig (1), USP1-11 (3), USP 5-19 (6); já o parental USP 2-16 (4) mostrou-se com mais genes dominantes. Em Anhembi, os parentais Hartwig (1), USP 2-16 (4) MTBR 123.800 (5) e USP 5-19 (6) contém mais genes recessivos e o parental USP1-11 (3) possui mais genes dominantes. Já o parental Conquista (2) encontra-se numa posição intermediária. Estes resultados são bastante divergentes de um local para o outro, discordando dos obtidos por Kaw \& Menon (1983) que obtiveram uma correlação $(r=0,76)$ alta e positiva para APF.

Em relação aos caracteres estudados na maturidade (Tabela 5.1), os componentes $D$, $\mathrm{H}_{1}, \mathrm{H}_{2}$ e $\mathrm{F}$ foram significativos ( $p<0,01$ ) para os caracteres NDM (ESALQ e Anhembi) e APM na ESALQ; já em Anhembi apenas os componentes $\mathrm{H}_{1}, \mathrm{H}_{2}$ e $\mathrm{F}$ foram significativos para APM. $\mathrm{O}$ gmd foi de 1,25 e 1,48 para NDM, respectivamente na ESALQ e Anhembi. Para APM, o gmd foi 0,84 na ESALQ e 3,08 em Anhembi, revelando que para esse local a presença de sobredominância e a ação gênica dominante foram mais importantes que a aditiva. Já na ESALQ, a ação gênica aditiva foi mais importante para o caráter APM. A relação $\mathrm{d} / \mathrm{r}$ foi maior que a unidade para os dois caracteres nos dois locais avaliados, indicando que há maior freqüência de genes dominantes do que recessivos envolvidos no controle dos caracteres. Foi verificado também uma assimetria $(\mu v<0,25)$ entre as freqüências dos alelos com efeitos positivos $e$ 
negativos. Freire Filho (1988), obteve resultados semelhantes, tanto para NDM quanto para APM. 0 autor ainda ressalta que provavelmente a predominância da ação gênica dominante constatada deve-se ao fato do NDM reunir um conjunto de parentais precoces, que concentram genes para esse caráter. Também, por serem precoces, já tiveram sua variabilidade genética aditiva reduzida através do processo de seleção para precocidade. Os coeficientes de determinação genotipica no sentido restrito, para NDM e APM nos locais ESALQ e Anhembi, foram respectivamente 0,02 e 0,$13 ; 0,88$ e 0,21 . No sentido amplo foi de 0,99 . 0 coeficiente de determinação genotípica no sentido restrito foi bem inferior ao obtido por Soldini (1998) para APM. $O$ fato das estimativas serem baixas, enfatiza que o comportamento dos cruzamentos $F_{2}$ para esse caráter foi, em grande parte, determinado pelas causas ambientais. As variações na magnitude do coeficiente de determinação entre locais sugere que os genótipos não reagiram da mesma forma nos ambientes avaliados, devido à interação genótipo $\mathrm{x}$ ambiente. Laínez-Mejía (1996) também obteve diferentes valores para as herdabilidades quando foram avaliadas as gerações $F_{6}$ e $F_{7}$ em diferentes ambientes, sugerindo que a ampla variância entre os locais e a magnitude relativa da variância genética nas localidades, indicam a influência do ambiente no comportamento das progênies.

Através das figuras $5.3 a$ e $5.3 b$, pode-se observar a análise gráfica para NDM na ESALQ e Anhembi, respectivamente. Nos dois locais, verifica-se que a reta da regressão deve interceptar 0 eixo das covariâncias muito próximo da origem ou logo abaixo da mesma, de modo que há indicação de dominância completa com tendência à sobredominância; esta tendência é mais pronunciada em Anhembi. $O$ valor de $\mathrm{R}^{2}$ foi muito próximo da unidade para os dois locais, indicando ótimo ajuste dos pontos à reta de regressão. A correlação de $\hat{Y}_{i}$ e $\left(\hat{W}_{i}+\hat{V}_{i}\right)$ foi de 0,97 nos dois locais, valor este muito próximo de um; então, os genes dominantes devem estar atuando no sentido de diminuição do caráter, enquanto que os recessivos contribuiram para aumentar a expressão do caráter. Os parentais distribuiram-se muito próximos uns dos outros no gráfico Wi $N_{i}$, com exceção da linhagem MTBR 123.800 (5) que se colocou bastante distante das demais (Figuras 5.3a e 5.3b). Dessa maneira, a ordem da dominância foi a seguinte: Hartwig (1), USP1-11 (3), USP 2-16 (4) e USP 5-19 (6) em um extremo, tendo pequenas diferenças em termos do número de genes dominantes, e no outro extremo, o parental MTBR 123.800 (5) concentrando o maior número de genes recessivos. Este resultado concorda com o fato de que 
essa linhagem é proveniente do Mato Grosso e contém genes para tolerância ao fotoperíodo, sendo mais tardia em condições de latitudes superiores como é o caso de Piracicaba (latitude 220).

No caso do caráter APM (Figuras 5.4a e 5.4b), o comportamento não foi tão parecido nos dois locais como no caso anterior. Pelos gráficos, pode-se ver que a reta de regressão interceptou 0 eixo das covariâncias abaixo da origem nos dois locais, refletindo a ocorrência de sobredominância na expressão do caráter, estando de acordo com Freire Filho (1988) e Soldini (1998) em $F_{2}$ e com Raut et al. (2000) nas gerações $F_{1}, F_{2}$ e $F_{3}$. A correlação negativa relativamente alta $(-0,80)$ entre $\hat{Y}_{i}$ e $\left(\hat{W}_{i}+\hat{V}_{i}\right)$ indica que os alelos dominantes atuam no sentido de aumentar a altura das plantas na ESALQ, enquanto que em Anhembi ocorreu o oposto $(0,70)$; no entanto, a diferença em termos de média geral entre os locais foi muito pequena: ESALQ $=63,14 \mathrm{~cm}$ e Anhembi $=65,43 \mathrm{~cm}$ (Tabelas 3.5 e 3.6); já o efeito de ambiente ( $(\mathrm{k})$ (Tabela 4.6), atuou no sentido de aumentar a altura na ESALQ $\left(l_{k}=1,14\right)$, ocorrendo 0 oposto em Anhembi $\left(l_{k}=-1,14\right)$. Provavelmente, 0 forte efeito de ambiente seja uma explicação para a diferença no sinal da correlação entre $\hat{Y}_{i}$ e $\left(\hat{W}_{i}+\hat{V}_{i}\right)$ de um local para outro. Na ESALQ, os genótipos tiveram uma distribuição relativamente ampla ao longo da reta da regressão, relativamente ao local Anhembi. $O$ comportamento dos genótipos ao longo da reta também foi diferente, podendo-se observar que os parentais USP 2-16 (4), MTBR 123.800 (5) e USP 5-19 (6) estão em posições opostas ao longo da reta. Em Anhembi, o parental USP 5-19 (6) foi o único a se localizar na parte superior da reta de regressão, isso concorda com a média obtida em Anhembi (Tabela 3.9) que foi superior a todos os parentais. Por ser a correlação relativamente alta e positiva entre $\hat{Y}_{i}$ e $\left(\hat{W}_{i}+\hat{V}_{i}\right)$, pode-se dizer que esses parentais possuem genes recessivos agindo no sentido de aumentar 0 caráter.

Para o caráter $P G$ (Tabela 5.1), todos os componentes genéticos da variância (D, $F, H_{1}$ e $\mathrm{H}_{2}$ ) foram significativos ( $p<0,05$ e $p<0,01$ ). Os valores do gmd foram 0,73 (ESALQ) e 1,92 (Anhembi), indicando a presença de dominância parcial na ESALQ e de sobredominância no Anhembi. Esses resultados concordam com Bhatade et al. (1977), Leffel \& Weiss (1958), Freire Filho (1988) e Soldini (1998), todos envolvendo geração $F_{2}$. No entanto, discordam do resultado obtido na ESALQ, que mostrou ação gênica aditiva mais importante que a dominante; isso pode 
ser confirmado pelo alto valor de $D$ em relação a $F, H_{1}$ e $H_{2}$. A estimativa positiva e significativa de $F$, indica maior freqüência de genes dominantes do que recessivos nos parentais. A relação $\mu v$ foi de 0,14 na ESALQ e 0,20 em Anhembi; neste segundo caso, há um indicativo de que os alelos com efeitos negativos têm distribuição relativamente uniforme nos parentais no local Anhembi; pelo gráfico (Figura 5.5a) pode-se observar uma distribuição relativamente ampla dos genótipos na reta da regressão.

Ainda no que se refere a $P G$, os coeficientes de determinação genotipica no sentido restrito e amplo foram respectivamente de 0,77 e 0,97 para ESALQ. No local Anhembi, o coeficiente de determinação genotipica no sentido restrito foi de 0,34 , valor bem inferior ao encontrado na ESALQ, enquanto no sentido amplo foi de 0,94. Essas estimativas refletem a marcante presença de ação gênica dominante na expressão do caráter PG no local Anhembi. As estimativas de herdabilidade no sentido restrito para produtividade obtidos na literatura mostram ampla variação. Freire Filho (1988) obteve 0,13 , enquanto Soldini (1998) obteve 0,78 . No sentido amplo, a variação também foi grande. Pelas figuras $5.5 \mathrm{a}$ e $5.5 \mathrm{~b}$ pode-se observar que a reta de regressão intercepta 0 eixo das covariâncias abaixo da origem, evidenciado existência de sobredominância. A correlação entre $\hat{Y}_{i}$ e $\left(\hat{W}_{i}+\hat{V}_{i}\right)$ foi baixa nos dois locais, $r=0,06$ na ESALQ e $r=0,20$ no Anhembi; apesar disso, houve evidência de que os genes recessivos têm efeitos positivos sobre a produtividade. Resultados concordantes com os obtidos por Freire Filho (1988) e por Soldini (1998), com predominância dos alelos recessivos. A visualização dos parentais ao longo da reta de regressão mostra um posicionamento relativamente semelhante, embora na ESALQ tenha sido retirado dois parentais. Os parentais Hartwig (1), USP 2-16 (4) e MTBR 123.800 (5) contém mais genes recessivos nos dois locais. Já os parentais Conquista (2), USP111 (3) e USP 5-19 (6) foram os que apresentaram o maior número de genes dominantes; deve-se lembrar que na ESALQ apenas a USP 5-19 (6) esteve presente, pois os outros dois parentais foram eliminados da análise.

$\mathrm{O}$ caráter \%OL (Tabela 5.1) apresentou componentes genéticos da variância ( $\mathrm{D}, \mathrm{H}_{1} \mathrm{e}$ $\mathrm{H}_{2}$ ) significativos a 5 e $1 \%$ nos dois locais. O F não-significativo e positivo na ESALQ e negativo em Anhembi evidencia que pode haver maior frequência dos alelos dominantes em relação aos recessivos na ESALQ e o inverso em Anhembi, ou seja, pode haver uma leve predominância da frequência dos genes recessivos em relação aos dominantes. Valor positivo e não-significativo 
para \%OL também foi obtido por Soldini (1998) e Raut et al. (2000). O gmd foi superior à unidade nos dois locais, indicando sobredominância. $O$ valor $d / r$ foi maior que a unidade $(d / r=1,58)$ na ESALQ e d/r=0,72 em Anhembi, revelando a predominância dos genes dominantes envolvidos no controle do caráter apenas na ESALQ; já em Anhembi há um indicativo de maior frequência de genes recessivos. Efeitos significativos para a dominância também foram obtidos por Miranda et al. (1998), geralmente no sentido de aumentar o teor de óleo nas sementes. Entretanto, como $\hat{F}$ não foi significativo nos dois locais, esse resultado é apenas aproximado. $O$ resultado obtido em Anhembi mostra-se em desacordo com a ocorrência de sobredominância. Uma possivel explicação para isso é que pode haver maior número de genes recessivos de pequeno efeito, 0 que causaria $\mathrm{d} / \mathrm{r}<1$ e um menor número de genes dominantes com grande efeito de modo a causar o gmd maior que a unidade. Os resultados mostram também que a contribuição dos locos para o grau médio de dominância não foi uniforme nos dois locais: 0,16 - ESALQ e 0,15 Anhembi. Os coeficientes de determinação genotipica no sentido restrito e amplo foram respectivamente: 0,49 e 0,82 - ESALQ e 0,69 e 0,98 - Anhembi. Soldini (1998) encontrou herdabilidade no sentido restrito de 0,49 para \%OL; Montaño-Velasco (1994) encontrou uma herdabilidade no sentido amplo de 0,50 em $F_{3}$. Na geração $F_{2}$, Zimback (1992) estimou a média de $h^{2}=0,60$ para \%OL. A análise gráfica apresentada nas Figuras 5.6a e 5.6b mostra a presença de dominância parcial, pois a reta intersecciona 0 eixo das ordenadas acima da origem. $A$ correlação entre $\hat{Y}_{i}$ e $\left(\hat{W}_{i}+\hat{V}_{i}\right)$ foi baixa e negativa $(-0,0022)$ na ESALQ e um pouco mais elevada e positiva em Anhembi $(0,56)$. A correlação alta e negativa $(r \cong-1)$ indica que genes dominantes atuam no sentido de aumentar o caráter; correlação alta e positiva, evidencia que genes dominantes atuam no sentido de diminuir o caráter. A baixa correlação talvez advenha do fato do caráter \%OL ter pouca variabilidade nos genótipos avaliados. De maneira geral, pode-se dizer que os parentais se encontram muito próximos na reta de regressão nos dois locais, sendo que em Anhembi os parentais Hartwig (1), USP1-11 (3) contém mais genes recessivos, enquanto USP 2-16 (4) e MTBR 123.800 (5) possuem mais genes dominantes; USP 5-19 (6) encontra-se na posição intermediária.

No caráter PO (Tabela 5.1), apenas o $D$ foi significativo na ESALQ $(P<0,01)$. Já em Anhembi, os componentes significativos $(p<0,05$ e $p<0,01)$ foram $D, H_{1}$ e $H_{2}$. O gmd foi de 1,08, 
muito próximo da unidade na ESALQ e 2,36 em Anhembi, revelando a presença de dominância completa com tendência a sobredominância na ESALQ e sobredominância em Anhembi. A relação $d / r>1$ indica maior freqüência de genes dominantes nos parentais. A simetria $\mu \mathrm{v}=0,23$ (próximo de 0,25 ) na ESALQ e de $\mu v=0,20$ no Anhembi, indica que os alelos com efeitos positivos e os alelos com efeitos negativos têm distribuição relativamente uniforme nos parentais. Os coeficientes de determinação genotipica no sentido restrito e amplo foram respectivamente 0,61 e 0,98 na ESALQ e 0,36 e 0,95 em Anhembi. Nesse estudo, 0 caráter PO foi controlado por ação gênica dominante; em decorrência disso, a PO apresentou baixo coeficiente de determinação genotipica no sentido restrito, principalmente em Anhembi, fato esse confirmado pelos valores apresentados pelos componentes de variância e parâmetros genéticos. Pelos gráficos (Figuras 5.7a e 5.7b) pode-se concluir que os parentais USP 2-16 (4) e MTBR 123.800 (5) contém mais genes recessivos, USP 5-19 (6) possui mais genes dominantes, enquanto que 0 parental Hartwig ficou numa posição intermediária nos dois locais. A correlação entre $\hat{Y}_{i}$ e $\left(\hat{W}_{i}+\hat{V}_{i}\right)$ foi de 0,46 na ESALQ e 0,22 em Anhembi, mostrando a tendência de genes recessivos contribuirem para aumentar PO; fato semelhante ocorreu para $P G$, certamente em razão dos caracteres PO e PG estarem positivamente associados. Já para \%OL, observou-se tendência inversa desta agora relatada para $\mathrm{PO}$, ou seja, genes dominantes aumentam $0 \% \mathrm{OL}$.

Este estudo mostra que nestes niveis de homozigose os efeitos gênicos de dominância sobrepujam os efeitos gênicos aditivos para a maioria dos caracteres estudados. No entanto em niveis altos de homozigose os resultados na literatura afirmam que os efeitos aditivos são mais importantes, demonstrando ser importante desenvolver estudos que permitam avaliar os efeitos epistáticos. 


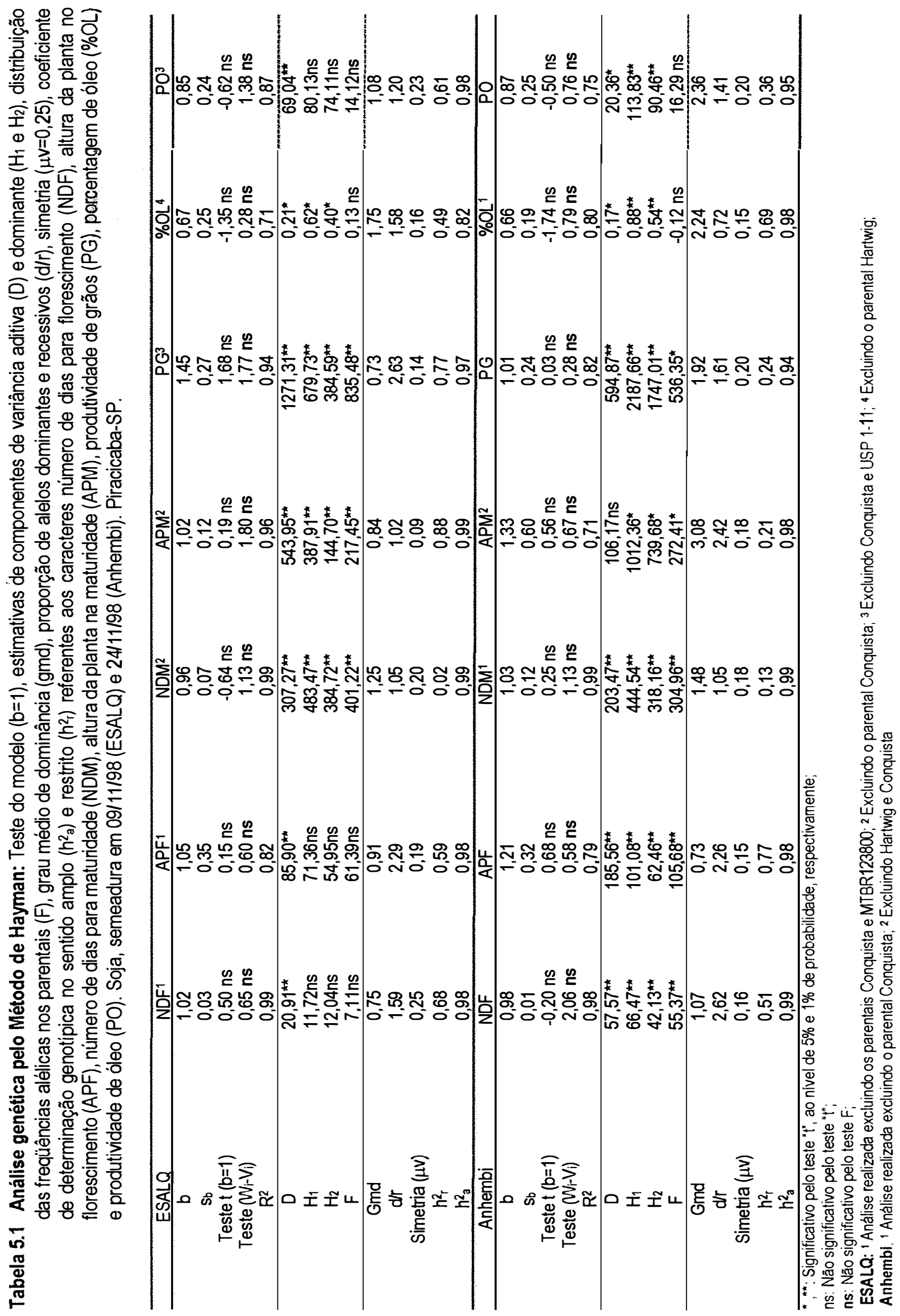




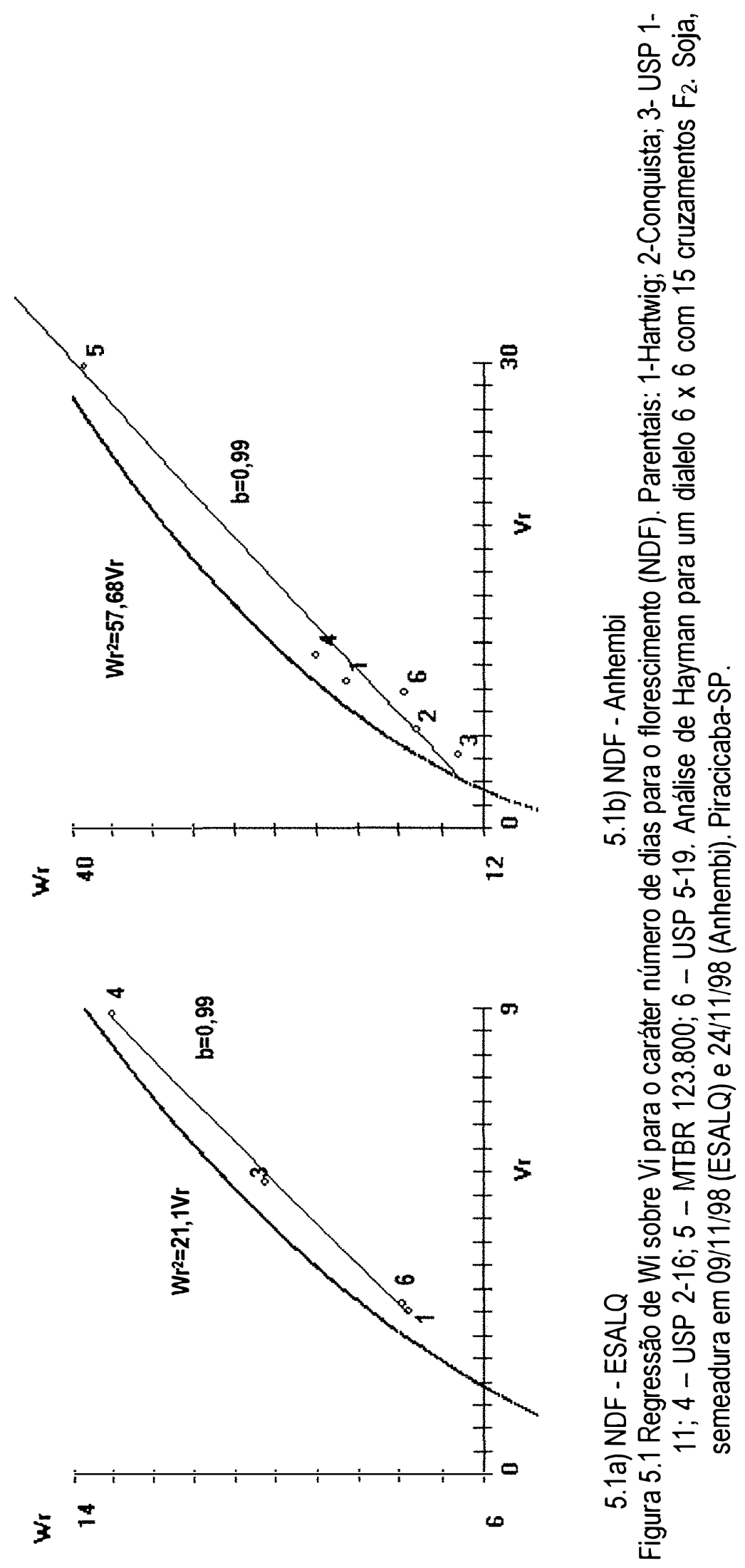




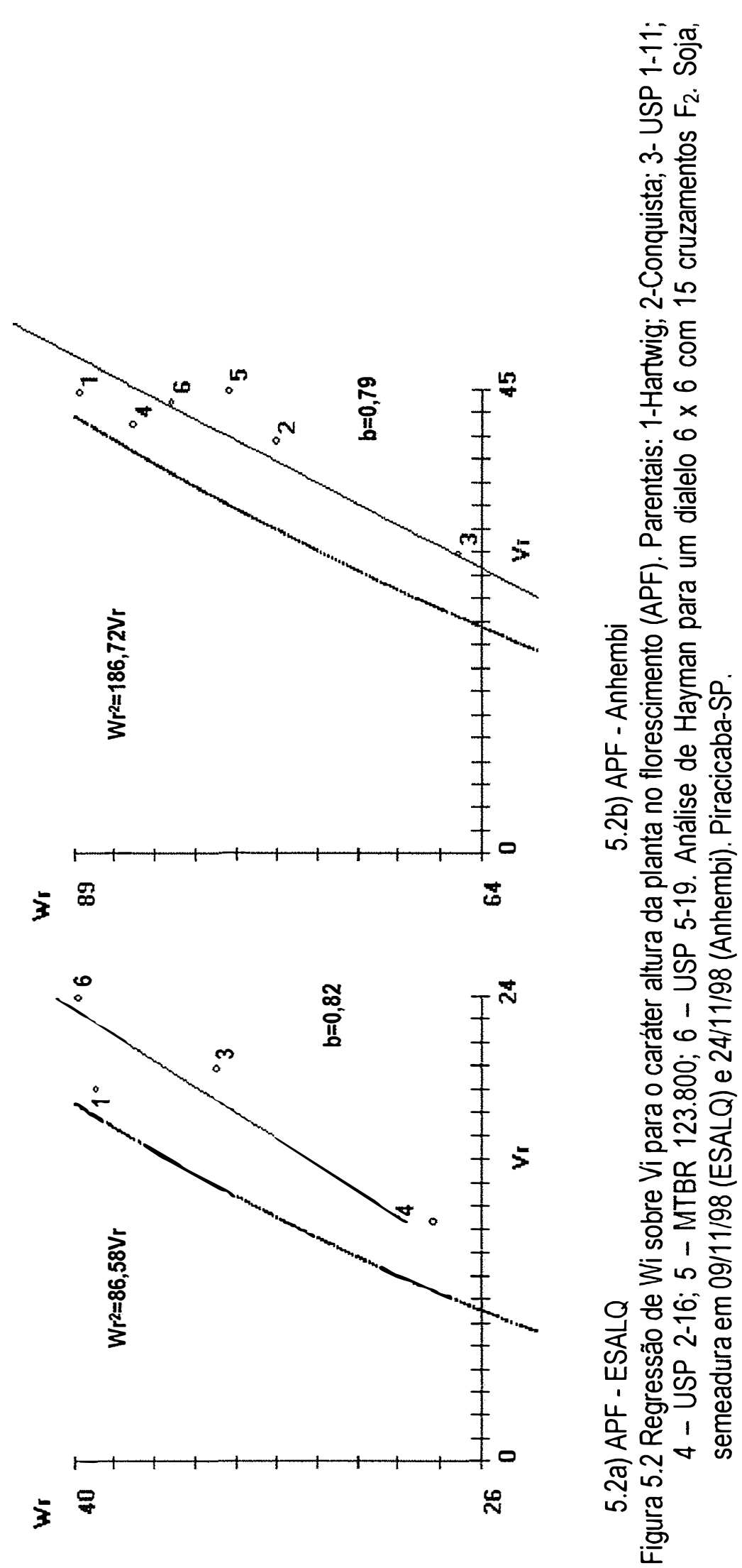




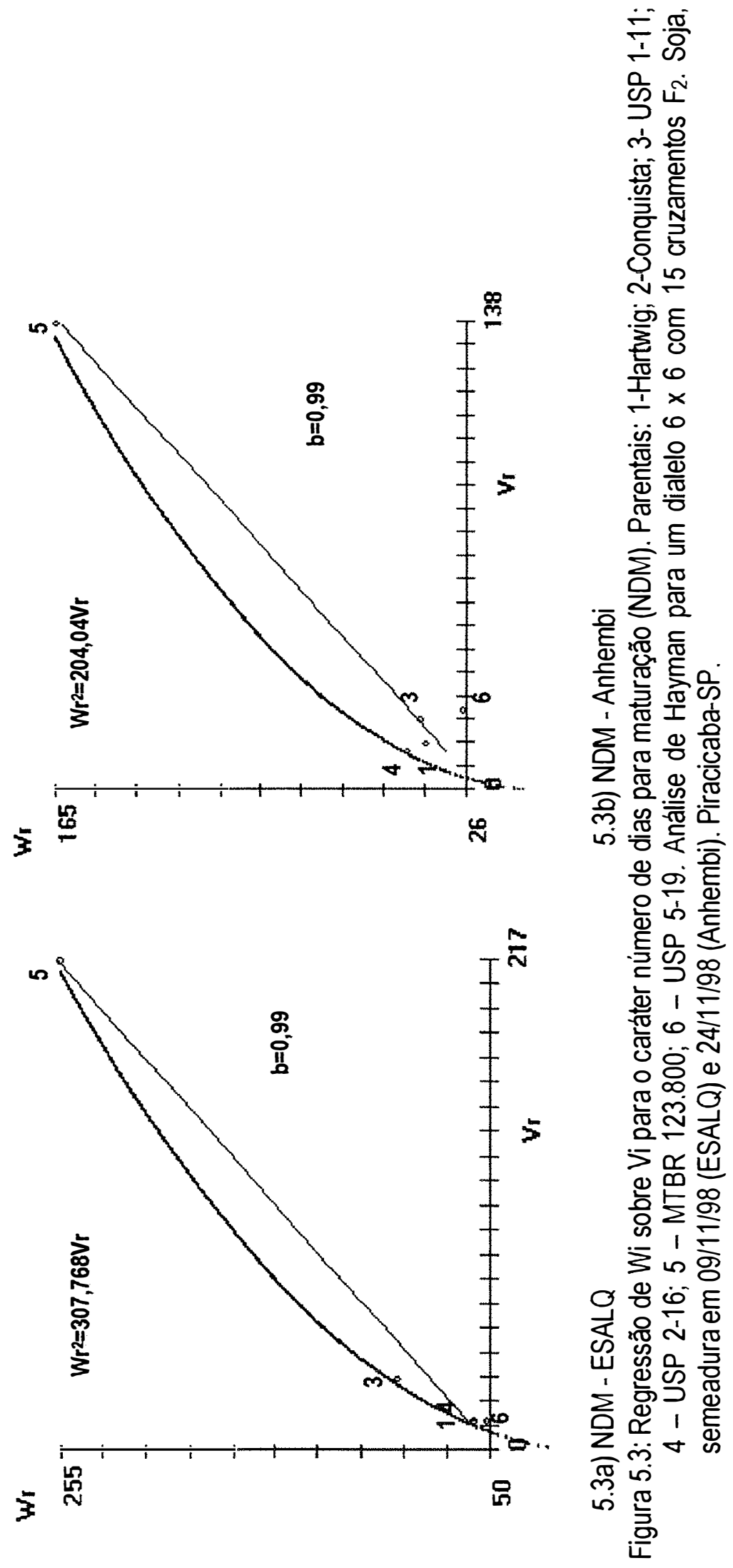




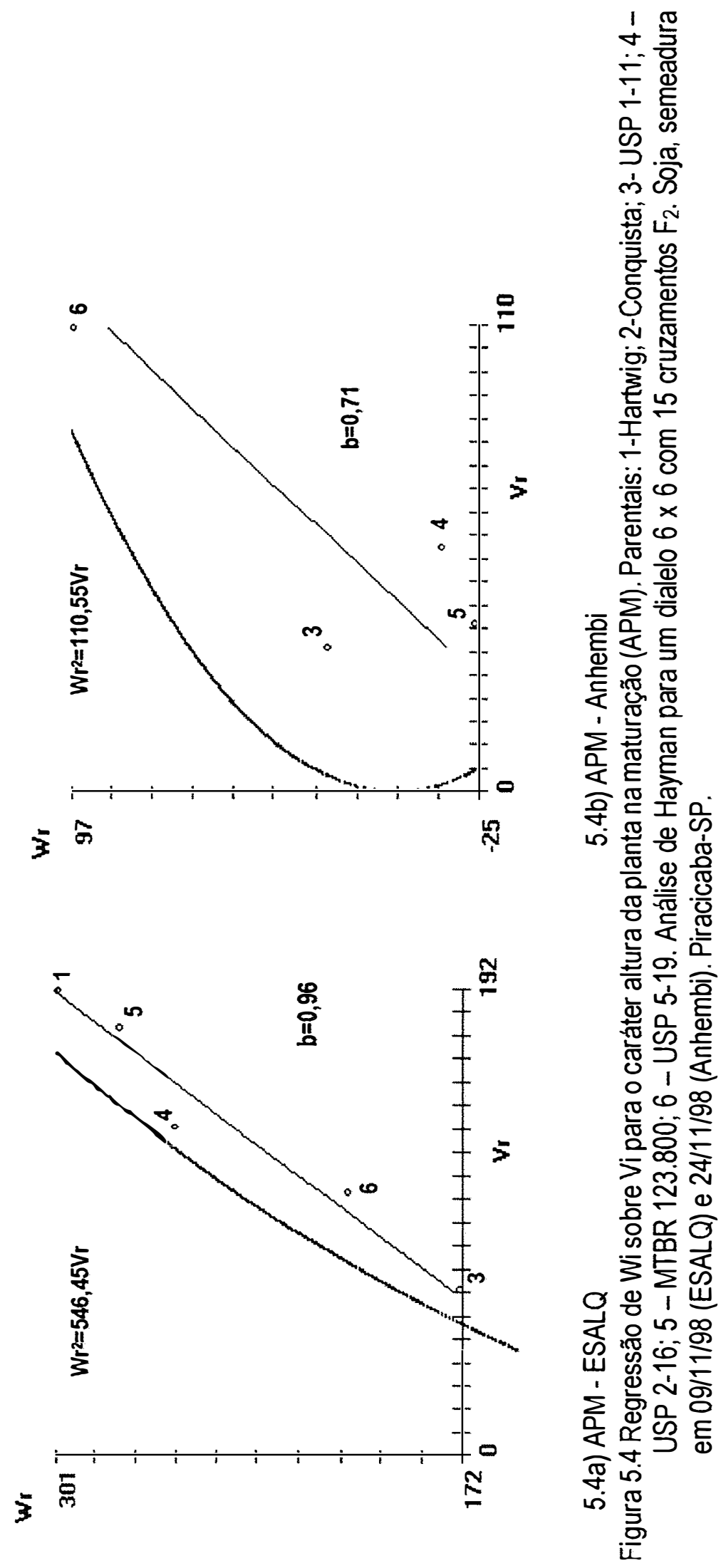



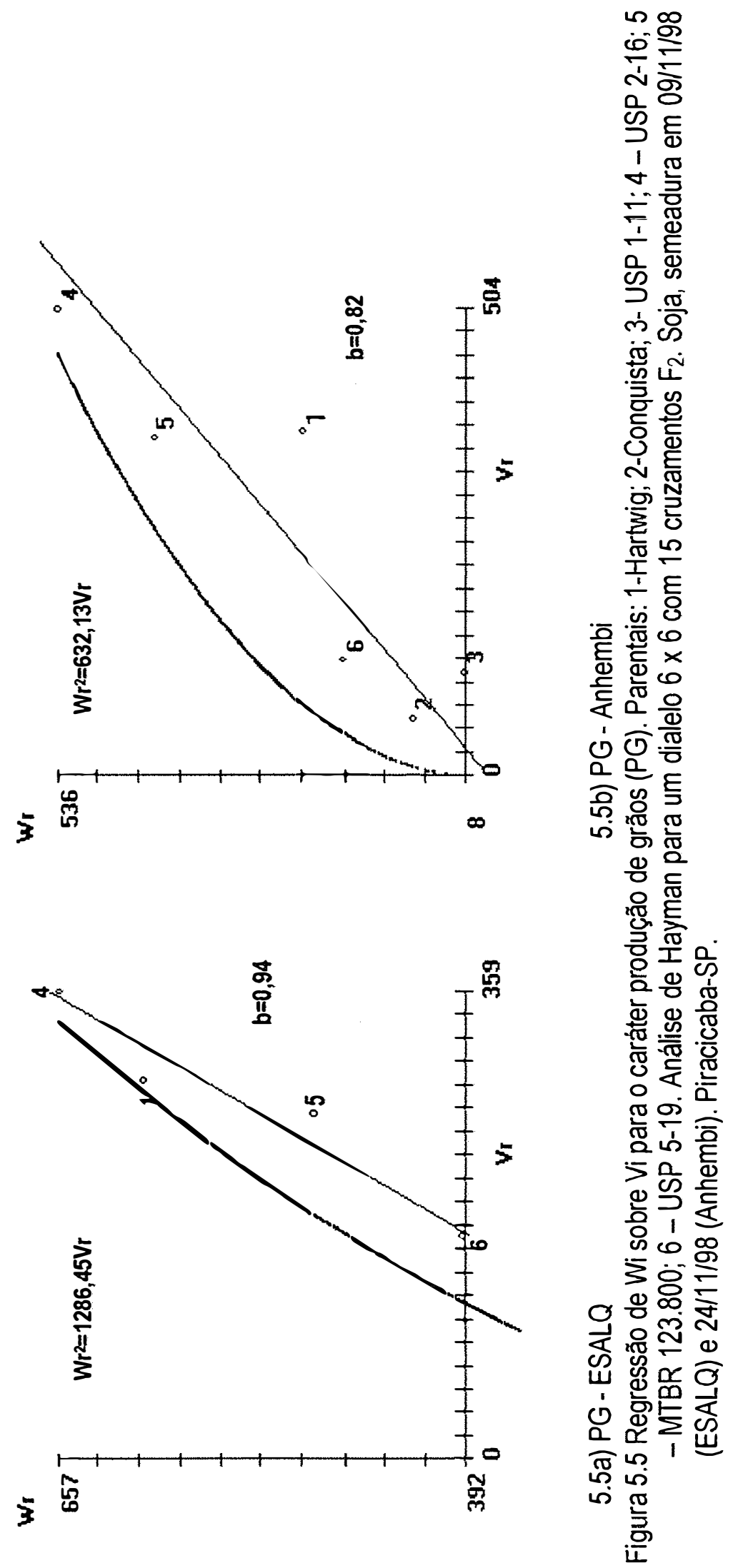

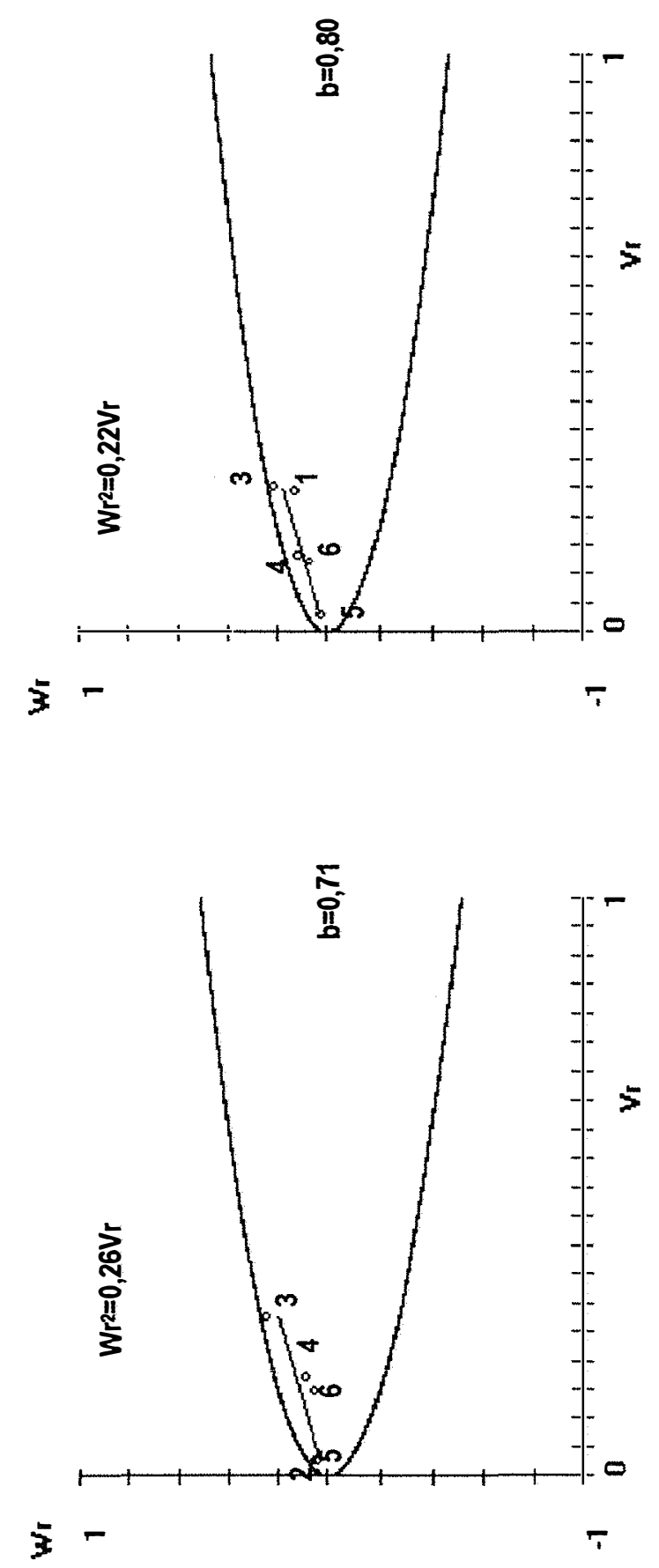

ํ E

के तु

1 \%

$\checkmark$ \&

Е

ㄷํㅇํㅇ

क

m

कृष

흠

등

Uิ

$\sim 0$

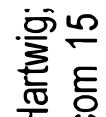

$\div 0$

is $x$

To

흘 잏 인

덩 즘

这

i。

융 응

응 은

응

हิ

즁

ఎे

흥 늘

눈

贾

㥕 क

잉

灾 1 \%

$>0 \%$

흥 官

管

웡 $\propto$

운 옹

出泡卢

ए 1 \%

유웛

응

需

눈 은 


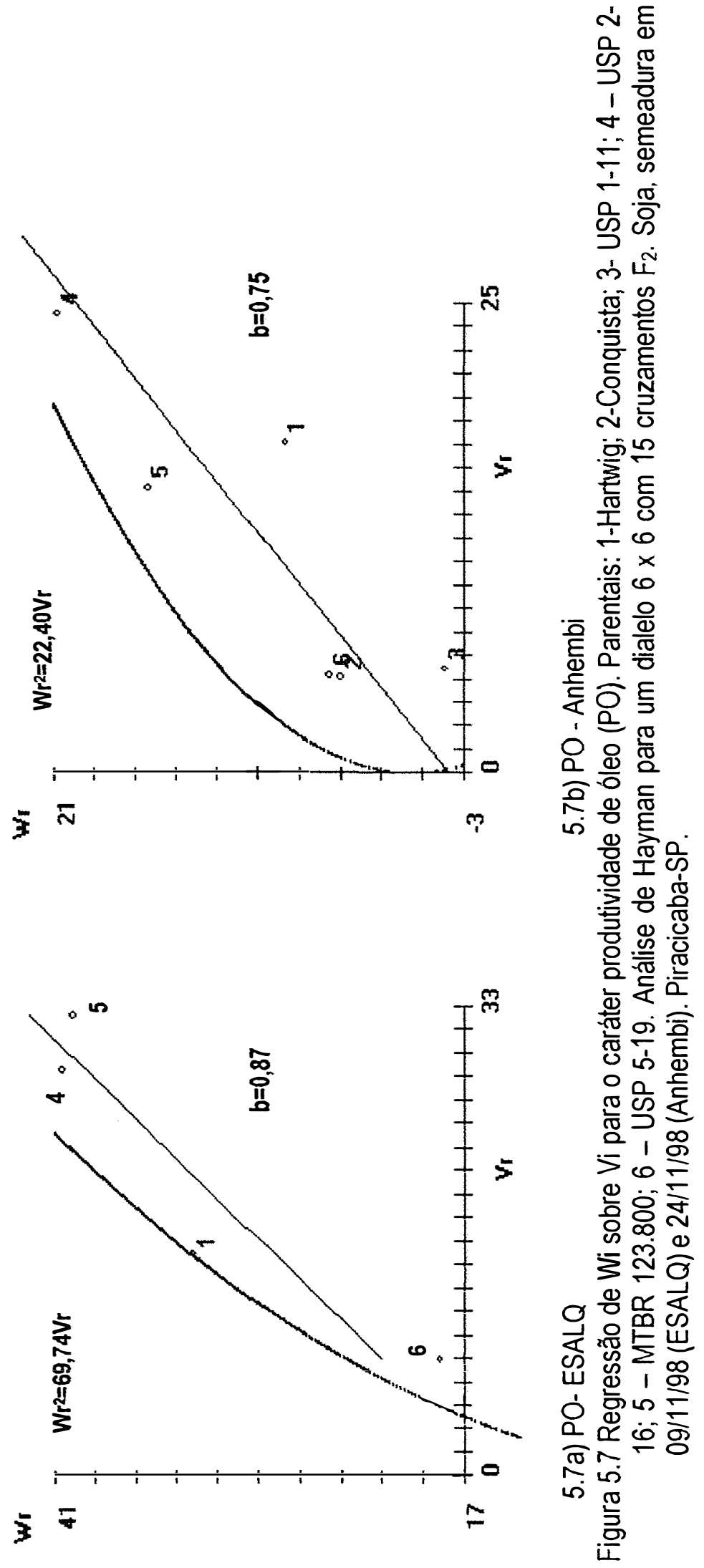




\section{CONCLUSÕES}

a) Os parentais e a geração $F_{2}$ apresentaram variabilidade para todos os caracteres tanto para locais individuais quanto combinados;

b) Destacaram-se os cruzamentos Conquista $\times$ USP 1-11 ( $2 \times 3)$, Conquista $\times$ USP 2-16 ( $2 \times 4)$ e Conquista $\times$ MTBR $123.800(2 \times 5)$, com altas médias para todos os caracteres nos dois locais; já o cruzamento USP 2-16 x MTBR $123.800(4 \times 5)$ também se destacou para a maioria dos caracteres somente em Anhembi;

c) Os dois locais foram bons para a expressão do potencial genético dos genótipos avaliados; no entanto, o local ESALQ mostrou-se mais indicado para avaliação de caracteres relacionados ao florescimento e maturidade, enquanto a produtividade de grãos foi favorecida em Anhembi;

d) A interação genótipos $\times$ locais $(G \times L)$ mostrou-se um importante componente da variação fenotípica para todos os caracteres, exceto para o teor de óleo $\left(F_{2} \times L\right)$;

e) As correlações genotípicas foram geralmente maiores que as fenotipicas e de ambiente nos dois locais; mostrando que o fenótipo refletiu satisfatoriamente o genótipo;

f) Tanto efeitos gênicos aditivos quanto de dominância foram importantes; no entanto, estes interagiram com locais, sugerindo a necessidade de se selecionar parentais e cruzamentos em ambientes especíicos;

g) Médias e efeitos de capacidade geral de combinação foram concordantes em classificar os genótipos;

h) As maiores estimativas de capacidade especifica de combinação ocorreram entre parentais com sinais contrários de capacidade geral de combinação. A contribuição do parâmetro sii (capacidade especifica de combinação do parental i com ele próprio), mostrou-se importante na expressão da heterose e da divergência entre parentais. A combinação destes parâmetros, juntamente com as interações dos mesmos com locais, foram importantes para o 
desempenho dos melhores cruzamentos, com destaque especial de Hartwig x USP 1-11 ( $1 \times$ 3);

i) A divergência de origem geográfica muito acentuada entre os parentais pode Ter sido responsável por dificuldades na adequação do modelo de Hayman;

j) A análise numérica detectou sobredominância para número de dias para maturidade, teor de óleo e produtividade de óleo na ESALQ e para todos os caracteres (exceto altura da planta no florescimento) em Anhembi. Efeitos genéticos aditivos também foram significativos em todos caracteres na ESALQ, enquanto em Anhembi apenas o caráter APM foi exceção. A análise gráfica detectou sobredominância para todos os caracteres e para a maioria deles não foi possivelestimar o limite teórico de seleção. 


\section{REFERÊNCIAS BIBLIOGRÁFICAS}

AKHTER, M.; SNELLER, C. H. Yield and yield components of early maturing soybean genotypes in the Mid-South. Crop Science, v.36, n.4, p.877-882, 1996 a.

AKHTER, M.; SNELLER, C. H. Genotype x planting date interaction and selection of early maturing soybean genotypes. Crop Science, v.36, n.4, p.883-889, 1996b.

ALLARD, R. W. Princípios do melhoramento genético de plantas. Rio de Janeiro Edgard Blucher, 1971.381p.

ALLIPRANDINI, L. F. Potencialidade de cruzamentos quádruplos de soja com ênfase na produtividade de grãos. Piracicaba, 1996. 174p. Tese (Doutorado) - Escola Superior de Agricultura "Luiz de Queiroz", Universidade de São Paulo.

ANAND, S. C. Registration of Hartwig soybean. Crop Science, v.32, n.4, p.1069-1070, 1992.

ARUNACHALAM, V. Evaluation of diallel crosses by graphical and combining ability methods. The Indian Journal of Genetics and Plant Breeding, v.36, p.358-366, 1976.

ASSMANN, I. C. Diversidade genética e análise dialélica em trigo (Tritucum aestivum (L.) Thell). Viçosa, 1999. 114p. Tese (Doutorado) - Universidade Federal de Viçosa.

BAKER, R. J. Issues in diallel analysis. Crop Science, v.18, n.4, p.533-536, 1978.

BHATADE, S. S.; SINGH, C. B.; TIWARI, A. S. Diallel analysis of yield and its components in soybean. Indian Journal of Agricultural Science, v.47, n.7, p.322-4, 1977.

BONATO, A. L. V. Avaliação da diversidade genética entre cultivares brasileiras de soja, através de marcadores AFLP. Piracicaba, 2000. 89p. Tese (Doutorado.)- Escola Superior de Agricultura "Luiz de Queiroz", Universidade de São Paulo.

BONATO, E. R.; VELLO, N. A. Aspectos genéticos do tempo para o florescimento em variantes naturais de soja. Pesquisa Agropecuária Brasileira, v.34, n.6, p.989-993, 1999.

BRIM, C. A.; COCKERHAM, C. C. Inheritance of quantitative characters in soybean. Crop Science, v.1, p.187-190, 1961. 
BURTON, J. W. Soyabean (Glycine $\max$ (L.) Merr.). Field Crops Research, n.53. p.171-86, 1997.

CAMACHO, M. L. H. Varianzas genéticas y heredabilidade de características vegetativas y reprodutivas de la soya Glycine max (L.) Merrill. Acta Agronomica, Palmira, v.21, n.4, p.139152,1971

CECON, P. R.; MORAIS, R. A. ; SEDIYAMA, C. S. Obtenção da herdabilidade e das correlações genotipicas, fenotipicas e de ambiente nas gerações $F_{2}$ e $F_{3}$ em cruzamentos fatoriais em soja. Pesquisa Agropecuária Brasileira, v.28, n.12, p.1399-1406, 1993.

$\mathrm{CHO}$, Y. K. ; SCOTT, R. A. Combining ability of seed vigor and seed yield in soybean. Euphytica,v.112, n.2, p.145-150, 2000.

COMPANHIA NACIONAL DE ABASTECIMENTO. Indicadores da Agropecuária. CONAB, 2000. P.11.

CRUZ, C. D. Programa GENES: aplicativo computacional em genética e estatística. Viçosa: UFV, 1997, 442p.

CRUZ, C. D.; REGAZZI, A. D. Modelos biométricos aplicados ao melhoramento genético. Viçosa: UFV, 1994.390p.

CRUZ, C. D.; SEDIYAMA, C. S.; SEDIYAMA, T. Capacidade combinatória e efeitos reciprocos de alguns caracteres em soja [Glycine $\max$ (L.) Merrill]. Revista Ceres, Viçosa, v.34, n.194, p.432-439, 1987.

CRUZ, C. D.; VENCOVSKY, R. Comparação de alguns métodos de análise dialélica. Revista Brasileira de Genética, v.12, n.2, p.425-438, 1989.

CUI, Z.; CARTER,T.E.; BURTON, J.W. Genetic base of 651 soybean cultivars released during 1923 to 1995. Crop Science, v.40, n.5, p.1470-1481, 2000.

DELANNAY, X.; RODGERS, D. M.; PALMER, R. G. Relative genetic contributions among ancestral lines to North American soybean cultivars. Crop Science. v.23, p.944-949, 1983.

DESTRO, D.; CARPENTIERI-PIPOLO, V.; KIIHL, R. A. S.; ALMEIDA, L. A. Photoperiodism and genetic control of the long juvenile period in soybean: a review. Crop Breeding and Applied Biotechnology, v.1, n.1, p.72-92, 2001.

FALCONER, D. S.; MACKAY, T. F. C. Introduction to quantitative genetics. Edinburgh: Longman, 1996, 463p. 
FARIA, L. C.; ROLIM, R. B.; SOUZA, P. I. M.; ARANTES, N. E. MG-BR-46 (Conquista) Extensão de indicação de cultivar de soja para o estado de Goiás e Distrito Federal. In: REUNIÃO DE PESQUISA DE SOJA DA REGIÃO CENTRAL DO BRASIL, 20., Londrina, 1998.; resumos. Londrina: EMBRAPANCNPSo, 1998. p.300-309. (EMBRAPACNPSO, Documentos, 121).

FEHR, W. R. Principles of cultivar development. New York: Macmillan, 1987. 536p.

FEHR, W. R.; CAVINESS, C. E. Stages of soybean development. Ames: lowa State University, Ames, 1977, 12p. (Special Report, 80).

FERREIRA, D. F. ; REZENDE, G. D. S. P.;RAMALHO, M. A. P. An adaptation of Griffing's method IV of complete diallel cross analysis for experiments repeated in several environments. Revista Brasileira de Genética, v.16, n.2, p.357-366, 1993.

FERREIRA, P. E. On Jinks-Hayman's analysis of half diallels. Revista Brasileira de Genética, v.8, n.1, p.149-155, 1985.

FREIRE FILHO, F. R. Análise genética de um dialelo entre genótipos precoces de soja (Glycine $\max$ (L.) Merrill. Piracicaba, 1988. 224p. Tese (Doutorado) - Escola Superior de Agricultura "Luiz de Queiroz", Universidade de São Paulo.

GADAG, R. N.; UPADHYAYA, H. D.; GOUD, J. V. Geneti analysis of yield, protein, oil and other related traits in soybean. Indian Journal of Genetics and Plant Breeding, v.59, n.4, p.487492, 1999.

GARDNER, C. O.; EBERHART, S. A. Analysis and interpretation of the variety cross diallel and related populations. Biometrics, v.22, n.18, p.439-452, 1966.

GIZLICE, Z.; CARTER Jr, T. E.; BURTON, J. W. Genetic diversity in North American soybean: I. Multivariate analysis of founding stock and relation to coefficient of parentage. Crop Science, v.33, n. 3, p.614-620, 1993.

GIZLICE, Z.; CARTER Jr, T. E.; BURTON, J. W. Genetic base of North American public cultivars released between 1947 and 1988. Crop Science, v.34, p.1143-1151, 1994.

GIZLICE, Z.; CARTER Jr, T. E.; GERIC, T. M.; BURTON, J. W. Genetic diversity patters in North American public soybean cultivars based on coefficient parentage. Crop Science, v.36, p.753$765,1996$. 
GRIFFING, B. A. Concept of general and specific combining ability in relation to diallel crossing systems. Australian Journal Biological Sciences, v.9, n.4, p.463-493, 1956 a.

GRIFFING, B. Generalised treatment of the use of diallel crosses in quantitative inheritance. Heredity, v.10, n.1, p.31-50, 1956 b.

HALLAUER, S. R. ; MIRANDA FILHO, J. B. Quantitative genetics in maize breeding. 2. ed. Ames: lowa State University Press, 1988, 468p.

HANSON, W.D.; WEBER, C.R. Resolution of genetic variability in self-pollinated species with an application to the soybean.. Genetics, v.46, n.11, p.1425-1434, 1961.

HANSON, W. D.; WEBER, C. R. Analysis of genetic variability from generations of plant progeny lines in soybean. Crop Science, v.2, p.63-67, 1962.

HAYMAN, B. I. The analysis of variance of diallel tables. Biometrics, v.10, n.40, p.235-244, $1954 a$.

HAYMAN, B. I. The theory and analysis of diallel crosses. Genetics, v.39, n.6,p.789-809, 1954 b.

HAYMAN, B. I. The theory and analysis of diallel crosses:II. Genetics, v.43, n.13,p.63-85, 1958

HEGSTAD, J. M.; BOLLERO, G.; NICKELL, C. D. Potential of using plant row yield trials to predict soybean yield. Crop Science, v.39, n.6, p.1671-1675, 1999.

HERNÁNDEZ, J. A.; VEGA, O. U. Estudio de la herencia en líneas de maiz através del diseño dialélico de Hayman. Revista Facultad de Agronomía, v.22, p.121-137, 1996.

HIROMOTO, D.M. Seleção de genótipos de soja para performance agronômica e resistência a Heterodera glycines Ichinohe e Diaporthe phaseolorum f.sp. meridionalis Morgan-Jones. Piracicaba, 1996. 84p. Tese (Doutorado) - Escola Superior de Agricultura "Luiz de Queiroz", Universidade de São Paulo.

HIROMOTO, D. M.; VELLO, N. A. The genetic base of Brazilian soybean (Glycine max. (L.) Merrill) cultivars. Revista Brasileira de Genética. v.9, n.2, p.295-306, 1986.

HYMOWITZ, T. On the domestication of the soybean. Economy Botany, v.24, n.4, p.408-421, 1970.

JINKS, J. L. The analysis of continuous variation in a diallel cross of Nicotiana rustica varieties. Genetics, v.39, n.6, p.767-788, 1954.

JINKS, J. L. The $F_{2}$ and backcross generations from a set of diallel crosses. Heredity, v.10, n.1, p.1-30, 1956. 
JINKS, J. L.; HAYMAN, B. I. The analysis of diallel crosses. Maize Genetics Cooperation Newsletter, Ithaca, v.27, p.48-54, 1953.

KAW, R. N.; MENON, P. M. Combining ability in soybean. Indian Journal of Genetics, v.40, p.305-309, 1980 .

KAW, R. N.; MENON, P. M. Diallel analysis in soybean. Indian Journal of Agricultural Science, v.52, n.12, p.991-997, 1983.

KEMPTHORNE, O. The theory of the diallel cross. Genetics, v.41, n.4, p.451-459, 1956.

KEMPTHORNE, O. An introduction to genetic statistics. Ames: lowa State University Press, 1969. $545 p$.

KISHA, T. J.; DIERS, B. D. Allel contribution of parents to select progeny from two-way crosses. Soybean Genetics Newsletter, v.24, p.190-193, 1997.

KISHA, T. J. ; SNELLER, C. H. ; DIERS, B. W. Relationship between genetic distance among parents and genetic variance in populations of soybean. Crop Science, v.37, n.4, p.13171325, 1997.

KRIEGER, M. Análise dialélica envolvendo dez parentais semi-precoces de soja (Glycine max (L.) Merrill). Piracicaba, 1992. 65p. Dissertação (M.S.)- Escola Superior de Agricultura "Luiz de Queiroz", Universidade de São Paulo.

KUNTA, T.; EDWARDS,L. H.; MCNEW, R. W.; DINKINS, R. Heterosis performance and combinig ability in soybeans. Soybean Genetics Newsletter, v.12, p.97-99, 1985.

LAÍNEZ-MEJIA, J. R. Implicações da interação genótipos $x$ ambientes na seleção de progênies de soja com ênfase nas produtividades de grãos e óleo. Piracicaba, 1996. 145p. Tese (Doutorado) - Escola Superior de Agricultura "Luiz de Queiroz", Universidade de São Paulo.

LEFFEL, R. C.; WEISS, M. G. Analysis of diallel crosses among ten varieties of soybeans. Agronomy Journal, v.50, p.528-534, 1958.

LI, X.. H.; CHEN, W. M.; LI, Z. L. Analysis of gene effects for some important agronomic characters sin summer soybean. Acta Agronomica Sinica, v.17, p.453-460, 1991.

LIU, K. H. Analysis of combining ability and heritability of protein, oil and others components of $F_{2}$ of soybean. Acta Agronomica Sinica, v.14, n.4, p.303-399, 1988. 
LOISELLE, F.; VOLDENG, H. D.; TURCOTTE, P.; ST-PIERRE, C. A. Analysis of agronomic characters for an eleven-parent diallel of early-maturing soybean genotypes in eastem Canada. Canadian Journal of Plant Science, v.70, n.1, p.107-115, 1990.

MANJARREZ-SANDOVAL, P.; CARTER JUNIOR, T. E.; WEBB, D. M. ; BURTON, J. W. Coefficient of parentage and RFLP markers: Are they useful in predicting genetic variance in soybean populations? Soybean Genetics Newsletter, v.23, p.197-202, 1996.

MATHER, K.; JINKS, J. L. Biometrical Genetics. 2.ed. London: Chapman \& Hall, 1971. 328p.

MATHER, K.; JINKS, J. L. The study of continuous variations. London: Chapmann and Hall, 1982. 396p.

MELO, P. C. T. Heterose e capacidade combinatória em um cruzamento dialélico parcial entre seis cultivares de tomate (Lycopersicun esculentum Mill). Piracicaba, 1987. 110p. Tese (Doutorado) - Escola Superior de Agricultura "Luiz de Queiroz", Universidade de São Paulo.

MIRANDA FILHO, J. B.; GERALDI, I. O. An adapted models for the analysis of partial diallel crosses. Revista Brasileira de Genética, v.8, p.677-688, 1984.

MIRANDA, F. T. S. Interação genótipos $x$ ambientes em linhagens de soja selecionadas para resistência ao nematóide de cisto. Piracicaba, 1999. 141p. Dissertação (Mestrado) - Escola Superior de Agricultura "Luiz de Queiroz", Universidade de São Paulo.

MIRANDA, J. E. C. Análise genética de um cruzamento dialélico em pimentão (Capsicum annum L.). Piracicaba, 1987. 159p. Tese (Doutorado) - Escola Superior de Agricultura "Luiz de Queiroz", Universidade de São Paulo.

MIRANDA, J. E. C.;MALUF, W. R.; CAMPOS,J. P. Análise genética de um cruzamento dialélico de cultivares de tomate. Pesquisa Agropecuária Brasileira, v.17, n.5, p.767-773, 1982.

MIRANDA, Z. F. S.; ARIAS, C. A. A. ; TOLEDO, J. F. F. ; OLIVEIRA, M. F. Soybean seed oil content: genetic control under different photoperiods. Genetics and Molecular Biology, v.21, n.3, p.387-394, 1998.

MONTAÑO-VELASCO, J. C. Análise genética de progênies $\mathrm{F}_{3}$ de soja derivadas de cruzamentos em cadeia com ênfase na produção de óleo. 1994. 115p. Tese (Doutorado) - Escola Superior de Agricultura "Luiz de Queiroz", Universidade de São Paulo. 
MORAIS, A. R. ; OLIVEIRA, A. C.; GAMA, E.E.G.;SOUZA JUNIOR, C. L. A method for combined analysis of the diallel crosses repeated in several environments. Pesquisa Agropecuária Brasileira, v. 26, n.3, p.371-381, 1991.

MORO, G. L. ; REIS, M. S.; SEDIYAMA, C. S.; SEDIYAMA, T.; OLIVEIRA, A. B. Correlação entre alguns caracteres agronômicos em soja (Glycine max (L.) Merrill). Revista Ceres, v.39, n.223, p.225-232, 1992.

MORRISON, M. J.; VOLDENG, H. D.; COBER, E. R. Agronomic Changes from 58 years of genetic improvement of short-season soybean cultivars in Canada. Agronomy Journal, v.92, n.4, p.780-784, 2000.

NASS, L. L. Potencialidade de genótipos de soja (Glycine max (L.) Merrill) para cultivo de inverno avaliada por cruzamentos dialélicos Piracicaba, 1989. 112p. Dissertação (M.S.) - Escola Superior de Agricultura "Luiz de Queiroz", Universidade de São Paulo.

OLIVEIRA, A. C. MORAIS, A. R.; SOUZA JUNIOR, C. L.; GAMA, E. E. G. Análise de cruzamentos dialélicos parciais repetidos em vários ambientes. Revista Brasileira de Genética, v.10, n.3, p.517-553, 1987.

OSBORN, T. B.; MENDEL, L. B. The use of soy bean as food. J. Biol. Chem. n.32, p.369-387, 1917.

PACOVA, B. E. V. Análise genética de progênies segregantes de soja apropriada para 0 consumo humano. Piracicaba, 1992. 217p. Tese (Doutorado)- Escola Superior de Agricultura "Luiz de Queiroz", Universidade de São Paulo.

PALUDZYSZYN FILHO, E. Análise do potencial genético de cultivares de soja [Glycine max (L.) Merrill] através de cruzamentos dialélicos. Piracicaba, 1982. 94p. Dissertação (Mestrado)Escola Superior de Agricultura "Luiz de Queiroz", Universidade de São Paulo.

PASCHAL, E. H. ; WILCOX, J. R. Heterosis and combining ability in exotic soybean germplasm. Crop Science, v.15, n.1, p.344-349, 1975.

PELUZIO, J. M. Interação cultivar $x$ ambiente e correlações fenotipicas, genotípicas e de ambientes entre cultivares de soja no Estado do Tocantins. Viçosa, 1996. 81p. Tese (Doutorado) - Universidade Federal de Viçosa. 
PIMENTEL, A. M. Cruzamentos dialélicos em soja com ênfase em teor de proteína e produção de grãos. Piracicaba, 1991. 150p. Dissertação (M.S.) - Escola Superior de Agricultura "Luiz de Queiroz", Universidade de São Paulo.

PULCINELLI, C. E. Avaliação de cruzamentos dialélicos de soja em gerações avançadas de endogamia. Piracicaba, 1997. 165p. Tese (Doutorado) - Escola Superior de Agricultura "Luiz de Queiroz", Universidade de São Paulo.

PUSHPENDRA; RAM, H. H. Dry matter yield as an effective selection criterion in soybean. Tropical Agriculture, v. 67, n. 1, p.57-60, 1990.

RAMALHO, M. A. P.; SANTOS, J. B.; ZIMMERMANN, M. J. O. Genética quantitativa em plantas autógamas: aplicação ao melhoramento do feijoeiro. Goiânia: UFG, 1993. 271p.

RANA, J. C.; GUPTA, V. P. Response to selection and early generation evaluation in pea. Indian Journal of Genetic \& Plant Breeding. v.53, n.3, p.269-72, 1993.

RANALI, P.; CUBERO, J. I. Bases for genetic improvement of grain legumes. Fields Crops Research,v.53, p.69-82, 1997.

RASMUSSON, D. C. ; PHILLIPS, R. L. Plant breeding progress and diversity from de novo variation and elevated epistasis. Crop Science. v.37, n.2, p.303-310, 1997.

RAUT, V. M.; TAWARE, S. P. ; HALVANKAR, G. B. Gene effects for some quantitative characters in soybean (Glycine max) crosses. Indian Journal of Agricultural Sciences, v.70, n.5, p.334-335, 2000.

RAY, J. D.; HINSON, K.; MANKONO, J. E. B.; MALO, M. F. Genetic-control of a long-juvenile trait in soybean. Crop Science, v.35, n.4, p.1001-1006, 1995.

ROCHA, M. M. Interação genótipos x locais em linhagens experimentais de soja com diferentes ciclos de maturação. Piracicaba, 1998. 98p. Dissertação (Mestrado) - Escola Superior de Agricultura "Luiz de Queiroz", Universidade de São Paulo.

ROCHA, M. M.; VELLO, N. A. Interação genótipos e locais para rendimento de grãos de linhagens de soja com diferentes ciclos de maturação. Bragantia, v.58, n.1, p.69-81, 1999.

ROMAGOSA, I.; FOX, P. N. Genotype $x$ environment interactions and adaptation. In: HAYWARD, M. D. ; BOSEMARK, N. O. ROMAGOSA, I. Plant Breeding: principles and prospects. London : Chapman \& Hall, 1993, capitulo 20, p.375-390. 
ROUPAKIAS, D.; ZESOPOULOU, A.; KAZOLEA, S.; DALKALITSES, G.; MAVROMATIS, A.; LAZARIDOU, T. Effectiveness of early generation selection under two plant densities in faba bean (Vicia faba L.). Euphytica. v.93, p.63-70, 1997.

SAS, INSTITUTE. SASISTAT software: changes and enhancements through release 6.12. Cary: Statistical Analysis System Institute, 1997.1116p.

SCOTT, R. A.; KEPHART, K. D. Selection for yield, protein, and oil in soybean crosses between adapted and introduced parents. Field Crops Research, v.49, n.2-3, p.177-185, 1997.

SHARMA, S. K. Note on path-coefficient analysis in the $F_{2}$ populations of soybean grown at two locations. Indian Journal of Agricultural Sciences, v.49, n.10, p.820-821, 1979.

SHARMA, S. K.; PHUL, P. S. Combinig ability analysis in soybean. Indian Journal of Genetics and Plant Breeding, v.54, n.3, p.281-286, 1994.

SHARMA, S. K.; MEHTA, H., SOOD, V. K. Effect of cropping systems on combining ability and gene action for grain yield and its components in soybean. Field Crops Research, v.34, n.1, p.15-22, 1993.

SINGH, D. Diallel cross analysis for combining ability over different environments. The Indian Journal of Genetics \& Plant Breeding, v.33, n.2, p.127-136, 1973 a.

SINGH, D. Diallel analysis for combining ability over several environments - II. The Indian Journal of Genetics \& Plant Breeding, v.33, n.3, p.469-482, 1973b.

SINGH, D. Diallel analysis for combining ability over environments. The Indian Journal of Genetics \& Plant Breeding, v.39, n.3, p.383-386, 1979.

SINGH, R. J.; HYMOWITZ, T. Soybean genetic resources and crop improvement. Genome, v.42, n.4, p.605-616, 1999.

SINGH, T. P.; SINGH, K. B.; BRAR, J. S. Diallel analysis in soybean. Indian Journal of Genetics and Plant Breeding, v.34, n.3, p.427-432, 1974.

SNELLER, C. H. Pedigree analysis of elite soybean lines. Crop Science. v.34, p.1515-1522, 1994.

SOLDINI, D. O. Interação genótipos x locais e correlações entre caracteres com ênfase na produtividade de óleo em soja. Piracicaba, 1993. 136p. Dissertação (Mestrado) - Escola Superior de Agricultura "Luiz de Queiroz", Universidade de São Paulo. 
SOLDINI, D. O. Potencial genético de cruzamentos dialélicos parciais de soja com ênfase nas produtividades de grãos e óleo. Piracicaba, 1998. 80p. Tese (Doutorado) - Escola Superior de Agricultura "Luiz de Queiroz", Universidade de São Paulo.

SOOD, O. P.; SOOD, V. K.; ANAND, D.; KALIA, N. R. Phenotypic stability for yield and maturity in soybean (Glycine max) in mid-hills of Himachal Pradesh. Indian Journal of Agricultural Sciences, v.69, n.7, p.536-537, 1999.

SOUSA, J. A de. Estimação de parâmetros genéticos em um dialelo de pimenta (Capsicum chinense Jacq). Lavras, 1998. 91p. Tese (Doutorado) - Universidade Federal de Lavras.

SPEHAR, C. R. Diallel analysis for mineral element absorption in tropical adapted soybeans (Glycines max (L.) Merrill). Theorical and Applied Genetics, v.90, n.5, p.707-713, 1995.

SPEHAR, C. R. Diallel analysis for grain yield and mineral absortion rate of soybeans grown in acid brazilian savannah soil. Pesquisa Agropecuária Brasileira, v.34, n.6, p.1003-1009, 1999.

SPEHAR, C. R.; GALWEY, N. W. Diallel analysis for aluminium tolerance in topical soybeans (Glycines max (L.) Merrill). Theorical and Applied Genetics, v.92, n.2, p.267-272, 1996.

SPRAGUE, G. F.; TATUM, L. A. General vs specific combining ability in single crosses of corn. Journal of American Society of Agronomy. v.34, n.3, p.923-932, 1942.

SRIVASTAVA, A. N.; JAIN, J. K. Variability and coheritability estimates for physiological and economic attributes in soybean. Indian Journal of Genetics, v.54, n.2, p.179-183, 1994.

SRIVASTAVA, R. L.; AHMAD, Z.; SINGH, H. G.; SAXENA, J. K. Combinig ability for yield and related attributes in soybean. Indian Journal of Agricultural Sciences, v.48, p.148-155, 1978.

TAWAR, M. L. ; MISHRA, A. K. ; RAO, S. K. Gene action in soybean. Indian Journal of Heredity, v.21, p.10-16, 1989.

TAWARE, S. P.; HALVANKAR, G. B.; RAUT, V. M.; PATIL, V. P. Variability, correlation and path analysis in soybean hybrids. Soybean Genetics Newsletter, v.24, p.96-98, 1997.

TOLEDO, J. F. F.; ALMEIDA, L. A. ; KIIHL, R. F. S. MENOSSO, O.G. Ganho genético em soja no Estado do Paraná via melhoramento. Pesquisa Agropecuária Brasileira, v.25, n.1, p.89-94, 1990. 
TOLEDO, J. F. F.; KIIHL, R. A. S. Análise do modelo genético envolvido no controle de dias para florescimento em soja. Pesquisa Agropecuária Brasileira, v.17, n.4, p.623-631, 1982a.

TOLEDO, J. F. F.; KIIHL, R. A. S. Métodos de análise dialélica do modelo genético em controle das características dias para floração e número de folhas trifolioladas em soja. Pesquisa Agropecuária Brasileira, v.17, n.5, p.745-755, 1982b.

TOLEDO, J. F. F.; OLIVEIRA, M. F. ; TSUTIDA, A. C.; KIIHL, R. Genetic-analysis of grown of determinate soybean genotypes under photoperiods. Revista Brasileira de Genética, v.16, n.3,p.713-748, 1993.

TOLEDO, J. F. F.; TRILLER, C.; DONATO, L. T.; OLIVEIRA, M. F.; TSUTIDA, A. C. Geneticanalysis of flowering in determinate soybean genotypes under photoperiods. Revista Brasileira de Genética, v.17, n.2, p.187-195, 1994.

TRILLER, C.; TOLEDO, J. F. F. Using the $F_{3}$ generation for predicting the breeding potencial of soybean crosses. Brazilian Journal of Genetics. v.19, n.2, p.284-94, 1996.

UNÊDA-TREVISOLI, S. H. Estabilidade fenotipica e potencialidade de progênies obtidas por cruzamentos óctuplos em soja. Piracicaba, 1999. 228p. Tese (Doutorado) - Escola Superior de Agricultura "Luiz de Queiroz", Universidade de São Paulo.

VELLO, N.A. Métodos de melhoramento da soja. In: SIMPÓSIO SOBRE A CULTURA E PRODUTIVIDADE DA SOJA, 4., Piracicaba, 1991. Anais. Piracicaba: FEALQ, 1992, p. 41-59. VELLO, N. A.; FEHR, W. R.; BAHRENFUS, J. B. Genetic variability and agronomic performance of soybean populations developed from plant introductions. Crop Science, v.24, p.511-514, 1984.

VELLO, N. A.; HIROMOTO, D. M.; AZEVEDO FILHO, A. J. B. V. Coeficient of parentage and breeding of Brazilian soybean germplasm. Revista Brasileira de Genética, v.11, n.3, p.679$697,1988$.

VELLO, N. A.; PIRES, C. E. L. S. Estratégias para a seleção de parentais. Revista Brasileira de Genética, v.15, n.1, p.45-49, 1992. Suplemento./Apresentado ao 38. Congresso Nacional de Genética, Rio de Janeiro, 1992 - Resumol

VELLO, N.A.; HIROMOTO, D.M. FERREIRA, B.M.; BOOTAN, A.J. KIIHL, R.A.S. USP 01 A USP 11:Novas linhagens de soja resistentes ao nematóide de cisto, cancro da haste, mancha olhode-rã. Revista Brasileira de Genética. v.17, p.362, 1994. 
VENCOVSKY, R.; BARRIGA, P. Genética biométrica no fitomelhoramento. Ribeirão Preto: Sociedade Brasileira de Genética, 1992.496p.

YAMANAKA, N.; NAGAMURA, Y; TSUBOKURA, Y. et al. Quantitative trait locus analysis of flowering time in soybean using a RFLP linkage map. Breeding Science, v.50, n.2, p.109115, 2000. /Resumol

ZIMBACK, L. Cruzamento em cadeia entre genótipos adaptados e exóticos de soja com ênfase na produção de óleo. Piracicaba, 1992. 163p. Tese (Doutorado) - Escola Superior de Agricultura "Luiz de Queiroz", Universidade de São Paulo. 